\title{
Molecular and clinical significance of fibroblast growth factor 2 (FGF2 /bFGF) in malignancies of solid and hematological cancers for personalized therapies
}

\author{
Mohamed R. AkI ${ }^{1}$, Poonam Nagpal ${ }^{1}$, Nehad M. Ayoub ${ }^{2}$, Betty Tai ${ }^{1}$, Sathyen A. \\ Prabhu ${ }^{1}$, Catherine M. Capac ${ }^{1}$, Matthew Gliksman ${ }^{1}$, Andre Goy ${ }^{3}$ and K. Stephen \\ Suh $^{1}$ \\ ${ }^{1}$ Genomics and Biomarkers Program, The John Theurer Cancer Center, Hackensack University Medical Center, Hackensack, \\ NJ, USA \\ 2 Department of Clinical Pharmacy, Faculty of Pharmacy, Jordan University of Science and Technology, Irbid, Jordan \\ ${ }^{3}$ Lymphoma Division, The John Theurer Cancer Center, Hackensack University Medical Center, Hackensack, NJ, USA \\ Correspondence to: K. Stephen Suh, email: ksuh@HackensackUMC.org \\ Keywords: bFGF, FGF2, diagnosis, prognosis, malignancy, \\ Received: October 20, $2015 \quad$ Accepted: March 10, $2016 \quad$ Published: March 19, 2016
}

\section{ABSTRACT}

Fibroblast growth factor (FGF) signaling is essential for normal and cancer biology. Mammalian FGF family members participate in multiple signaling pathways by binding to heparan sulfate and FGF receptors (FGFR) with varying affinities. FGF2 is the prototype member of the FGF family and interacts with its receptor to mediate receptor dimerization, phosphorylation, and activation of signaling pathways, such as Ras-MAPK and PI3K pathways. Excessive mitogenic signaling through the FGF/ FGFR axis may induce carcinogenic effects by promoting cancer progression and increasing the angiogenic potential, which can lead to metastatic tumor phenotypes. Dysregulated FGF/FGFR signaling is associated with aggressive cancer phenotypes, enhanced chemotherapy resistance and poor clinical outcomes. In vitro experimental settings have indicated that extracellular FGF2 affects proliferation, drug sensitivity, and apoptosis of cancer cells. Therapeutically targeting FGF2 and FGFR has been extensively assessed in multiple preclinical studies and numerous drugs and treatment options have been tested in clinical trials. Diagnostic assays are used to quantify FGF2, FGFRs, and downstream signaling molecules to better select a target patient population for higher efficacy of cancer therapies. This review focuses on the prognostic significance of FGF2 in cancer with emphasis on therapeutic intervention strategies for solid and hematological malignancies.

\section{INTRODUCTION}

The fibroblast growth factor (FGF) family consists of 23 FGF signaling polypeptides that function as potent mitogens [1-3]. FGFs exert broad mitogenic activity by stimulating the growth of fibroblasts, endothelial, and cancer cells. The family plays important roles in embryonic development, maintenance of adult organ systems, tissue regeneration, wound repair, and hematopoiesis. FGF2, also known as basic FGF (bFGF), is the prototypical and most studied member of the FGF superfamily. FGF2 is an important regulator of cell growth and differentiation under physiological and pathological conditions [1-3]. Previous studies have suggested a role of FGF2 as a prognostic marker for different types of malignancies. This review summarizes the biology of FGF signaling by demonstrating biological roles of FGF2 in regards to pathogenesis and prognosis of solid and hematological tumors with a special focus on clinical development of FGF2 inhibitors in the era of personalized medicine.

FGF2 isoforms, receptors, binding partners, and signaling

FGF2 exists in low and high molecular weight isoforms, which are translated from a single common 
mRNA through alternative translation-initiation codons [4]. Low molecular weight (LMW) FGF2 is an $18 \mathrm{kDa}$ protein translated from a conventional AUG start codon [5]. LMW FGF2 is found in the cytoplasm and nucleus and can be also secreted by target cells [6]. In order to initiate signaling, LMW FGF2 interacts with cell surface heparan sulfate proteoglycans (HSPGs) and fibroblast growth factor receptor (FGFR) in a ternary complex consisting of FGF2, FGFR, and HSPG resulting in activation of downstream signaling pathways, including Ras, Raf, MAPK and ERK (Figure 1A) [7]. High molecular weight (HMW) FGF2 isoforms (22-, 22.5-, 24-, and 34-kDa) are produced through translation initiation at CUG sites upstream and in frame of the AUG codon. HMW FGF2 localizes to the nucleus and signals independently of FGFRs [8]. Similar to HMW FGF2, LMW FGF2 can also function in the cytosol and nucleus of cells through endocytosis of activated FGF-FGFR complexes [9]. FGFR1 and FGF2 have been shown to co-localize in the nuclear matrix, where together they may co-activate transcription and thus control cell proliferation (Figure 1A) $[10,11]$.

Five FGFRs have been identified, four of which (1-4) are highly conserved single-pass transmembrane
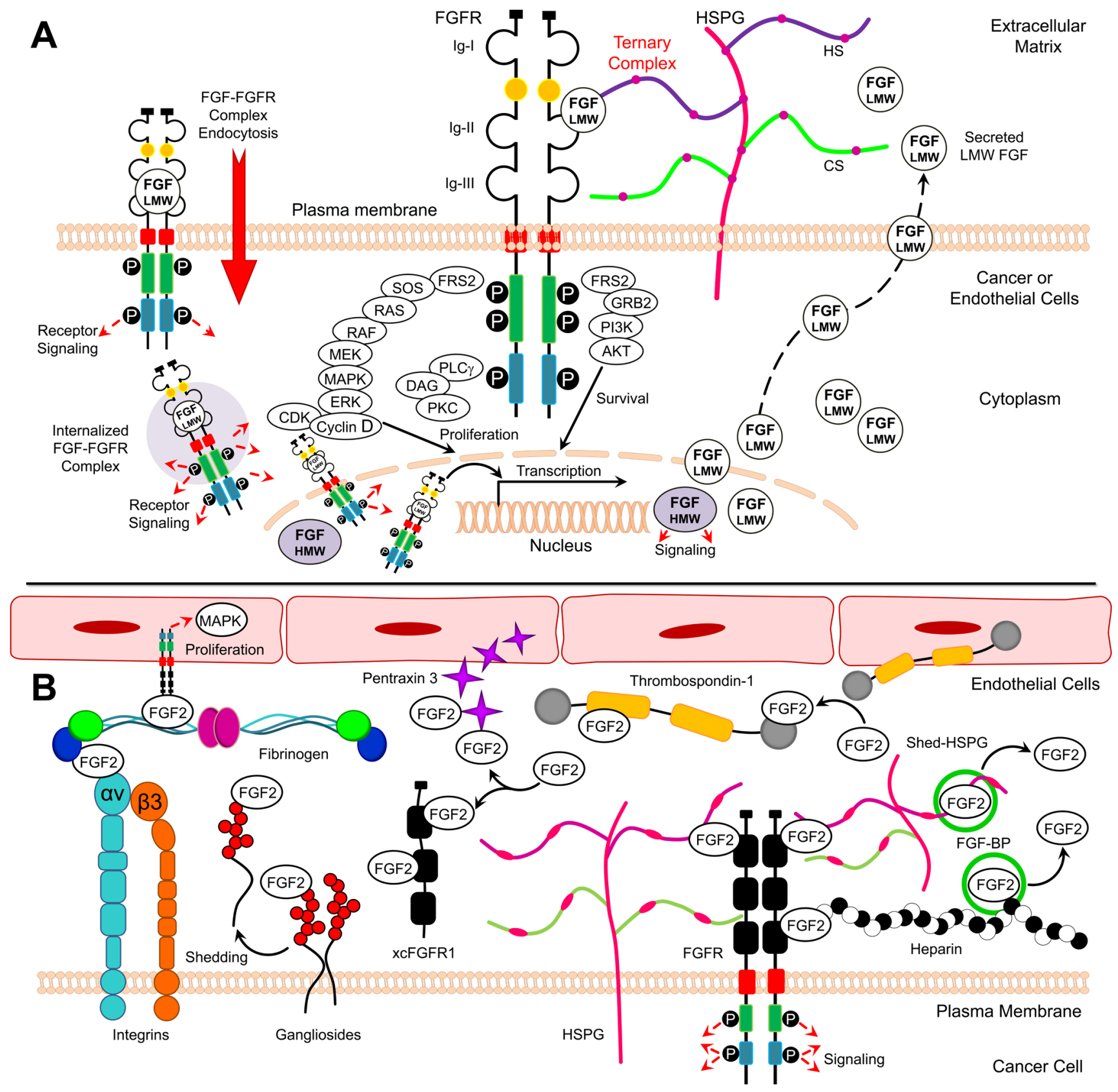

Figure 1: Model for FGF2/FGFR signaling and FGF2 binding partners. A. Structure of activated FGFR and downstream signaling B. FGF2 soluble and membranous binding partners. 
Table 1: FGF2 binding partners and associated proteins.

\begin{tabular}{|c|c|c|c|c|c|}
\hline $\begin{array}{l}\text { Associated } \\
\text { Protein }\end{array}$ & Association & Level of Interaction & Cell Type & Pathway & Ref \\
\hline FGFR(s) & $\begin{array}{l}\text { FGF2 binds to extracellular domain of FGFRs which } \\
\text { causes receptor dimerization and autophosphorylation } \\
\text { of tyrosine kinase residues on cytoplasmic domain }\end{array}$ & Cell membrane & $\begin{array}{l}\text { Endothelial cells, cancer } \\
\text { cells, fibroblasts }\end{array}$ & FGFR & $\begin{array}{l}{[12} \\
101]\end{array}$ \\
\hline HSPG & $\begin{array}{l}\text { FGF2 binds with low affinity to heparan sulfate chains } \\
\text { of HSPG. This interaction can activate intracellular } \\
\text { signaling, promote FGF2 internalization, or by } \\
\text { presenting FGF2 to FGFR in proper conformation. } \\
\text { HSPG also act as reservoirs for FGF2 which protect } \\
\text { them from degradation }\end{array}$ & Cell membrane & Cancer, endothelial cells & FGFR & $\begin{array}{l}{[102-} \\
104]\end{array}$ \\
\hline$\alpha v \beta 3$ integrin & $\begin{array}{l}\text { FGF2 binds to } \alpha v \beta 3 \text { integrin leads to assembly of focal } \\
\text { adhesion plaques }\end{array}$ & Cell membrane & Endothelial cells & FAK & {$[105]$} \\
\hline Gangliosides & $\begin{array}{l}\text { Gangliosides bind FGF2 via Neu-Ac residues and acts } \\
\text { as coreceptors }\end{array}$ & Cell membrane & Endothelial cells & FGFR & {$[106]$} \\
\hline Free gangliosides & $\begin{array}{l}\text { Exogenous gangliosides affect the angiogenic activity of } \\
\text { FGF2. Exogenous gangliosides act as FGF2 antagonists } \\
\text { when added to endothelial cell cultures }\end{array}$ & $\begin{array}{l}\text { Soluble or associated } \\
\text { with ECM }\end{array}$ & Cancer, endothelial cells & FGFR & {$[107]$} \\
\hline Heparin & $\begin{array}{l}\text { Short heparin chains bind FGF2, thus interfering with } \\
\text { mitogenic signaling through activation of FGFR, } \\
\text { relatively longer chains are expected to induce the } \\
\text { adverse effect of potentiating the mitogenic signaling }\end{array}$ & $\begin{array}{l}\text { Soluble or associated } \\
\text { with ECM }\end{array}$ & Tumor Cells & FGFR & {$[108]$} \\
\hline xcFGFR1 & $\begin{array}{l}\text { A soluble form of extracellular domain of FGFR1 which } \\
\text { binds to FGF2 which leads to suppression of FGF2/ } \\
\text { FGFR1 interaction }\end{array}$ & Soluble & Endothelial ECM & FGFR & {$[107]$} \\
\hline TSP & $\begin{array}{l}\text { TSP-1 and TSP-2 regulate angiogenesis through binding } \\
\text { and sequestration of FGF2 }\end{array}$ & $\begin{array}{l}\text { Soluble or associated } \\
\text { with ECM }\end{array}$ & Cancer, endothelial cells & FGFR & $\begin{array}{l}{[109,} \\
110]\end{array}$ \\
\hline РTX3 & $\begin{array}{l}\text { PTX3 prevents FGF2 binding to FGFRs on endothelial } \\
\text { cells, leading to inhibition cell proliferation and motility. } \\
\text { PTX3 suppressed neovascularization triggered by FGF2 } \\
\text { in the chick embryo chorioallantoic membrane }\end{array}$ & $\begin{array}{l}\text { Soluble or associated } \\
\text { with ECM }\end{array}$ & Endothelial cells & FGFR & {$[111]$} \\
\hline Fibrinogen/ fibrin & $\begin{array}{l}\text { Binding of FGF2 to fibrinogen or fibrin provides } \\
\text { protection of FGF2 from proteolytic degradation. } \\
\text { Fibrinogen potentiates FGF2-stimulated proliferation of } \\
\text { endothelial cells. Fibrinogen promotes growth of cancer } \\
\text { cells through interaction with FGF2 }\end{array}$ & $\begin{array}{l}\text { Soluble or associated } \\
\text { with ECM }\end{array}$ & $\begin{array}{l}\text { Endothelial cells, cancer } \\
\text { cells }\end{array}$ & FGFR & $\begin{array}{l}{[112,} \\
113]\end{array}$ \\
\hline$\alpha 2 \mathrm{M}$ & $\alpha 2 \mathrm{M}$ induces FGF2 expression in embryonic stem cells & Nucleus & Embryonic stem cells & ERK1/2, PI3K, & {$[114]$} \\
\hline PDGF & $\begin{array}{l}\text { FGF2 stimulates PDGFR- } \alpha \text { and } \beta \text { expression in } \\
\text { endothelial cells }\end{array}$ & Nucleus & Endothelial cells & Transcriptional & {$[115]$} \\
\hline PF4 & $\begin{array}{l}\text { PF4 inhibits FGF2-induced proliferation of endothelial } \\
\text { cells. PF-4 binds to FGF2 and inhibits FGF2 } \\
\text { dimerization, binding to FGFRs, and internalization }\end{array}$ & $\begin{array}{l}\text { Soluble or associated } \\
\text { with ECM }\end{array}$ & Endothelial cells & ERK & $\begin{array}{l}{[116,} \\
117]\end{array}$ \\
\hline uPA & $\begin{array}{l}\text { FGF2 upregulates uPA receptor and stimulates uPA } \\
\text { production by endothelial cells }\end{array}$ & Nucleus & Endothelial cells & Transcriptional & {$[118]$} \\
\hline CXCL13 & $\begin{array}{l}\text { CXCL13 chemokine displaces FGF2 binding to } \\
\text { endothelial cells, inhibits FGF2 homodimerization, and } \\
\text { induces the formation of CXCL13-FGF2 heterodimers }\end{array}$ & $\begin{array}{l}\text { Soluble or associated } \\
\text { with ECM }\end{array}$ & Endothelial cells & FGFR & {$[119]$} \\
\hline IL-6 & $\begin{array}{l}\text { FGF2 induces IL-6 release in human pancreatic } \\
\text { periacinar myofibroblasts. } \\
\text { Overexpression of FGF2 (24-kDa isoform) upregulates } \\
\text { IL-6 transcription in NIH-3T3 cells. FGF2 is } \\
\text { downstream effector of IL-6-induced angiogenic activity } \\
\text { in cancer cells }\end{array}$ & $\begin{array}{l}\text { Soluble or associated } \\
\text { with ECM/ Nucleus }\end{array}$ & Fibroblasts, cancer cells & $\begin{array}{l}\text { IL-6, ERK1/2 } \\
\text { and p38 MAP } \\
\text { kinases }\end{array}$ & $\begin{array}{l}{[120-} \\
122]\end{array}$ \\
\hline E-cadherin & $\begin{array}{l}\text { FGF2 downregulates E-cadherin expression through the } \\
\text { activation of PI3K/Akt/mTOR and MAPK signaling, and } \\
\text { upregulates Slug and ZEB1 in human ovarian cancer } \\
\text { cells }\end{array}$ & Nucleus & Cancer, endothelial cells & $\begin{array}{l}\mathrm{PI} 3 \mathrm{~K} / \mathrm{Akt} \text { and } \\
\text { ERK }\end{array}$ & {$[123]$} \\
\hline $\mathrm{Bcl}-2$ & $\begin{array}{l}\text { FGF2 downregulates Bcl-2 and promotes apoptosis in } \\
\text { human breast cancer cells }\end{array}$ & Nucleus & Cancer cells & Transcriptional & {$[124]$} \\
\hline Aquaporin 3 & $\begin{array}{l}\text { Aquaporin3 is required for FGF2-induced cell migration } \\
\text { in human breast cancer cells }\end{array}$ & $\begin{array}{l}\text { Soluble or associated } \\
\text { with ECM }\end{array}$ & Cancer cells & $\begin{array}{l}\text { Trans-epithelial } \\
\text { fluid transport }\end{array}$ & {$[125]$} \\
\hline Translokin & $\begin{array}{l}\text { Translokin interacts specifically with LMW FGF2. } \\
\text { Inhibiting Translokin expression by RNA interference } \\
\text { reduces the translocation of FGF2 }\end{array}$ & $\begin{array}{l}\text { Soluble or associated } \\
\text { with ECM }\end{array}$ & Fibroblasts & $\begin{array}{l}\text { FGF2 } \\
\text { trafficking }\end{array}$ & {$[126]$} \\
\hline Thrombin & $\begin{array}{l}\text { Thrombin cleaves HMW FGF2 into a LMW FGF2- } \\
\text { like form that stimulates endothelial cell migration and } \\
\text { proliferation }\end{array}$ & $\begin{array}{l}\text { Soluble or associated } \\
\text { with ECM }\end{array}$ & Endothelial, cancer cells & $\begin{array}{l}\text { Endothelial cell } \\
\text { migration }\end{array}$ & {$[127]$} \\
\hline $\begin{array}{l}\text { FGF-binding } \\
\text { protein }\end{array}$ & $\begin{array}{l}\text { FGF-BP } 1 \text { binds FGF2 and enhances FGF2-dependent } \\
\text { proliferation of NIH-3T3 fibroblasts and FGF2-induced } \\
\text { extracellular signal-regulated kinase } 2 \text { phosphorylation }\end{array}$ & $\begin{array}{l}\text { Soluble or associated } \\
\text { with ECM }\end{array}$ & $\begin{array}{l}\text { Squamous, epithelial } \\
\text { cells, fibroblasts }\end{array}$ & FGFR & {$[128]$} \\
\hline
\end{tabular}

a2M: $\alpha 2$-macroglobulin; ECM: extracellular matrix; FAK: focal adhesion kinase; HSPG: heparan sulfate proteoglycan; IL-6: interleukin-6; PDGF: platelet-derived growth factor; PF4: platelet factor 4; PTX3: p; TSP: thrombospondin-2; uPA: urokinase-type plasminogen activator 
Table 2: Studies evaluating FGF2 as a prognostic biomarker in cancer patients with solid tumors.

\begin{tabular}{|c|c|c|c|c|c|c|c|c|}
\hline $\begin{array}{l}\text { Cancer } \\
\text { Type }\end{array}$ & $\begin{array}{l}\text { Patient } \\
\text { Number }\end{array}$ & $\begin{array}{l}\text { Specimen } \\
\text { Type }\end{array}$ & $\begin{array}{l}\text { Cancer } \\
\text { Subtype }\end{array}$ & Method & FGF2 Expression Pattern & Prognosis & Associated with & Ref \\
\hline \multirow{2}{*}{$\begin{array}{l}\text { Bladder } \\
\text { Cancer }\end{array}$} & 32 & Resection & - & RT-PCR & $\begin{array}{l}\text { Elevated in high stage vs. low } \\
\text { stage patients }(p=0.001)\end{array}$ & - & $\begin{array}{l}\text { High stage, local } \\
\text { relapse }\end{array}$ & [129] \\
\hline & $\begin{array}{l}82 \text { vs. } 20 \\
\text { controls }\end{array}$ & $\begin{array}{l}\text { Untreated } \\
\text { serum }\end{array}$ & $\begin{array}{l}\text { Nonin- } \\
\text { vasive, } \\
\text { invasive }\end{array}$ & ELISA & $\begin{array}{l}(\uparrow) \text { FGF2 levels vs. controls } \\
(\mathrm{p}=0.083) ;(\uparrow) \text { FGF2 in noninva- } \\
\text { sive vs. invasive }(\mathrm{P}=0.013)\end{array}$ & $\begin{array}{l}\text { No significant } \\
\text { difference }\end{array}$ & $\begin{array}{l}\text { No correlation with } \\
\text { tumor grade, patient } \\
\text { age }\end{array}$ & {$[130]$} \\
\hline \multirow{8}{*}{$\begin{array}{l}\text { Breast } \\
\text { Cancer }\end{array}$} & 64 & $\begin{array}{l}\text { Cytosolic } \\
\text { extract }\end{array}$ & Primary & ELISA & $\begin{array}{l}(\uparrow)>2 \text { fold FGF2 levels in tumor } \\
\text { vs. controls and non-malignant } \\
\text { mastectomy specimens }(\mathrm{p}<0.01)\end{array}$ & - & - & {$[131]$} \\
\hline & 79 & Sections & - & $\mathrm{IHC}$ & $\begin{array}{l}(\uparrow) \text { FGF2 in } 38 \% \text { neoplastic cells, } \\
37 \% \text { in stromal cells }\end{array}$ & - & $\begin{array}{l}\text { Recurrence, aggres- } \\
\text { siveness }\end{array}$ & {$[132]$} \\
\hline & \multirow[t]{2}{*}{$\begin{array}{l}136 \text { vs. } 65 \\
\text { controls }\end{array}$} & $\begin{array}{l}\text { Diagnostic } \\
\text { biopsy, }\end{array}$ & \multirow[t]{2}{*}{$\begin{array}{l}\text { ER-(+) and } \\
(-) ; \operatorname{PR}(+) \\
\text { and }(-)\end{array}$} & $\mathrm{IHC}$ & $\begin{array}{l}\text { In } 84 \% \text { tumors FGF2 staining } \\
\text { limited to cytoplasm, } 16 \% \text { tumors } \\
\text { limited to both cytoplasm and } \\
\text { nuclei vs. positivity limited to the } \\
\text { cell nuclei of the basal layer of } \\
\text { mammary ducts in normal mam- } \\
\text { mary epithelium }\end{array}$ & \multirow[t]{2}{*}{-} & \multirow[t]{2}{*}{$\begin{array}{l}\text { Not correlated with } \\
\text { clinical, pathological } \\
\text { and biological charac- } \\
\text { teristics }\end{array}$} & \multirow[t]{2}{*}[133]{} \\
\hline & & Serum & & ELISA & $\begin{array}{l}(\uparrow) \text { in tumors vs. healthy controls } \\
(\mathrm{p}<0.001)\end{array}$ & & & \\
\hline & 111 & $\begin{array}{l}\text { Treated } \\
\text { resection }\end{array}$ & $\begin{array}{l}\mathrm{ER}(+/-)- \\
\mathrm{PR}(+/-)\end{array}$ & $\mathrm{IHC}$ & $\begin{array}{l}70 \% \text { tumors positive, } 30 \% \text { tumors } \\
\text { showed strong staining, }(\uparrow) \text { with } \\
\text { histological grade }(\mathrm{p}<0.05)\end{array}$ & $\begin{array}{l}(\downarrow) \text { OS in } \\
\text { FGF2 (+)vs. } \\
(-) \text { group in } \\
\text { negative nodal } \\
\text { status sub- } \\
\text { group }\end{array}$ & $\begin{array}{l}\text { Negatively corre- } \\
\text { lated with histological } \\
\text { grading }(\mathrm{p}<0.05)\end{array}$ & {$[134]$} \\
\hline & $\begin{array}{l}149,14 \text { non- } \\
\text { neoplastic, } 7 \\
\text { controls }\end{array}$ & Resection & Primary & ELISA & $\begin{array}{l}(\uparrow) \sim 3 \text { fold FGF2 in tumors } \\
\text { vs. non-neoplastic tissues }(\mathrm{p}< \\
0.0001) ;(\uparrow) \sim 12 \text { fold FGF2 in } \\
\text { tumors vs. normal control tissues } \\
(\mathrm{p}=0.0003)\end{array}$ & $\begin{array}{l}\text { No significant } \\
\text { difference }\end{array}$ & $\begin{array}{l}\text { No correlation } \\
\text { between FGF2 and } \\
\text { MVD }\end{array}$ & {$[135]$} \\
\hline & $\begin{array}{l}97 \text { vs. } 46 \\
\text { controls }\end{array}$ & $\begin{array}{l}\text { Untreated } \\
\text { nipple } \\
\text { aspirate } \\
\end{array}$ & $\begin{array}{l}\text { DCIS and } \\
\text { invasive }\end{array}$ & ELISA & $\begin{array}{l}(\uparrow) 11 \text { fold FGF2 in cancer pa- } \\
\text { tients vs. controls }(p<0.0001)\end{array}$ & - & $\begin{array}{l}\text { No correlation with } \\
\text { tumor stage, size, } \\
\text { nodal spread }\end{array}$ & {$[136]$} \\
\hline & 148 & $\begin{array}{l}\text { Untreated } \\
\text { resection }\end{array}$ & $\begin{array}{l}\text { Triple nega- } \\
\text { tive }\end{array}$ & $\mathrm{IHC}$ & $\begin{array}{l}13 \% \text { tumors positive vs. normal } \\
\text { breast tissue }\end{array}$ & $\begin{array}{l}\text { No significant } \\
\text { difference }\end{array}$ & Basal type cancer & {$[137]$} \\
\hline \multirow[b]{2}{*}{$\begin{array}{l}\text { Colorectal } \\
\text { Cancer }\end{array}$} & $\begin{array}{l}124,26 \\
\text { polyp pa- } \\
\text { tients, vs. } 55 \\
\text { controls } \\
\end{array}$ & Plasma & Primary & ELISA & $\begin{array}{l}(\uparrow) 1.8 \text { fold in tumor vs. normal } \\
\text { controls }(p=0.0004),(\downarrow) 0.6 \text { fold } \\
\text { in disease-free patients at follow } \\
\text { up vs. pre-operative }(p=0.0004)\end{array}$ & - & Metastasis & {$[138]$} \\
\hline & $\begin{array}{l}35 \text { ob- } \\
\text { structing } \\
\text { carcinoma, } \\
34 \text { non- } \\
\text { obstructing }\end{array}$ & $\begin{array}{l}\text { Untreated } \\
\text { resection }\end{array}$ & $\begin{array}{l}\text { Obstructing } \\
\text { and non- } \\
\text { obstructing }\end{array}$ & $\mathrm{IHC}$ & $\begin{array}{l}\text { ( } \uparrow) 1.7 \text { fold FGF } 2+\text { inflammatory } \\
\text { cell in obstructing vs. non-ob- } \\
\text { structing carcinoma ( } p=0.018) \text {; } \\
\text { no difference in FGF } 2 \text { between } \\
\text { obstructing vs. non-obstructing } \\
\text { carcinoma }\end{array}$ & - & $\begin{array}{l}\text { Hsp47 and stromal } \\
\text { myofibroblast fibrosis }\end{array}$ & {$[139]$} \\
\hline $\begin{array}{l}\text { Endo- } \\
\text { metrial } \\
\text { Cancer }\end{array}$ & $\begin{array}{l}134 \text { (type } \\
\mathrm{I}=70 \text { and } \\
\text { type } \mathrm{II}=64) \\
\text { vs. } 64 \text { con- } \\
\text { trols }\end{array}$ & $\begin{array}{l}\text { Untreated } \\
\text { serum }\end{array}$ & Type I and II & ELISA & $\begin{array}{l}(\uparrow) \sim 10 \text { and } 20 \text { fold FGF2 in type } \\
\text { I and type II, respectively vs. } \\
\text { healthy controls }\end{array}$ & $\begin{array}{l}(\downarrow) \text { OS and } \\
\text { DFS: in type } \\
\text { I with high } \\
\text { vs. low FGF2 } \\
\text { levels and type } \\
\text { II with high } \\
\text { vs. low FGF2 } \\
\text { levels } \\
\end{array}$ & $\begin{array}{l}\text { Advanced tumor } \\
\text { stages }\end{array}$ & {$[140]$} \\
\hline $\begin{array}{l}\text { Esopha- } \\
\text { geal } \\
\text { Cancer }\end{array}$ & $\begin{array}{l}70 \text { vs. } 20 \\
\text { controls }\end{array}$ & $\begin{array}{l}\text { Untreated, } \\
\text { treated tis- } \\
\text { sues }\end{array}$ & ESCC & $\begin{array}{l}\mathrm{IHC} \\
\mathrm{WB}\end{array}$ & $\begin{array}{l}\text { Positive expression in tumors vs. } \\
\text { absent in normal tissues }\end{array}$ & $\begin{array}{l}(\downarrow) 0.3 \text { fold } 2 \\
\text { yr RFS FGF2 } \\
\text { expression }((P \\
=0.005)\end{array}$ & $\begin{array}{l}\text { Local recurrence, } \\
\text { reduced RFS }\end{array}$ & {$[141]$} \\
\hline \multirow[b]{2}{*}{ Glioma } & 21 & $\begin{array}{l}\text { Untreated } \\
\text { resection }\end{array}$ & $\begin{array}{l}\text { Astrocy- } \\
\text { toma, Glio- } \\
\text { blastoma } \\
\end{array}$ & $\mathrm{IHC}$ & $\begin{array}{l}87 \% \text { tumors positive for FGF2 } \\
\text { expression vs. absent in normal } \\
\text { tissues }\end{array}$ & - & Degree of malignancy & {$[142]$} \\
\hline & 61 & Resection & Astrocytoma & $\mathrm{IHC}$ & $\begin{array}{l}44 \% \text { tumors had strong FGF2 } \\
\text { expression, stronger staining in } \\
\text { higher grades than lower grades } \\
(\mathrm{p}<0.05)\end{array}$ & \begin{tabular}{|l|} 
\\
$(\downarrow)$ survival in \\
tumors with \\
strong vs. \\
weak staining \\
\end{tabular} & High grade tumors & {$[143]$} \\
\hline $\begin{array}{l}\text { Head and } \\
\text { Neck }\end{array}$ & $\begin{array}{l}66 \text { vs. } 18 \\
\text { controls }\end{array}$ & Resection & $\mathrm{SCC}$ & $\begin{array}{l}\text { IHC, } \\
\text { ELISA }\end{array}$ & $\begin{array}{l}(\uparrow) \sim 12 \text { fold FGF2 expression in } \\
\text { tumors vs. control }(\mathrm{P}<\text { or }=0.05)\end{array}$ & - & Early stage disease & {$[144]$} \\
\hline
\end{tabular}




\begin{tabular}{|c|c|c|c|c|c|c|c|c|}
\hline \multirow[t]{2}{*}{$\begin{array}{l}\text { Liver } \\
\text { Cancer }\end{array}$} & 88 & $\begin{array}{l}\text { Untreated } \\
\text { serum }\end{array}$ & - & $\begin{array}{l}\text { IHC } \\
\text { and } \\
\text { ELISA }\end{array}$ & $(\uparrow)$ high serum FGF2 levels & $\begin{array}{l}(\downarrow) 0.5 \text { fold } \\
\text { months DFS in } \\
\text { patients with } \\
\text { high }(>10.8 \\
\mathrm{pg} / \mathrm{mL}) \text { vs. } \\
\text { low }(<10.8 \\
\mathrm{pg} / \mathrm{mL}) \mathrm{FGF} 2 \\
\text { level }\end{array}$ & $\begin{array}{l}\text { Tumor size, invasion, } \\
\text { advanced stage, } \\
\text { platelet count }\end{array}$ & {$[145]$} \\
\hline & 16 & $\begin{array}{l}\text { Untreated } \\
\text { resection }\end{array}$ & - & $\begin{array}{l}\text { IHC, } \\
\text { RT- } \\
\text { PCR, } \\
\text { WB } \\
\end{array}$ & $\begin{array}{l}\text { Positive expression in hepatoma } \\
\text { vs. absent in non-cancerous liver } \\
\text { cells }\end{array}$ & - & - & [146] \\
\hline \multirow{4}{*}{$\begin{array}{l}\text { Lung } \\
\text { Cancer }\end{array}$} & $\begin{array}{l}106 \text { vs. } 17 \\
\text { controls }\end{array}$ & Serum & $\begin{array}{l}\text { ACA, SCC, } \\
\text { SCLC }\end{array}$ & ELISA & $\begin{array}{l}(\uparrow) 2.5 \text { fold serum FGF2 levels } \\
\text { in tumors vs. normal controls ( } \mathrm{p}< \\
0.05 \text { ) }\end{array}$ & $\begin{array}{l}(\uparrow) \text { OS in } \\
\text { SCLC patients } \\
\text { with high }(> \\
5.4 \mathrm{pg} / \mathrm{ml}) \mathrm{vs} \text {. } \\
\text { low }(<5.4 \mathrm{pg} / \\
\text { ml } \text { FGF2 }\end{array}$ & - & {$[147]$} \\
\hline & 103 & $\begin{array}{l}\text { Untreated } \\
\text { serum }\end{array}$ & SCLC & ELISA & $\begin{array}{l}25 \% \text { patients had FGF2 } \geq 17 \mathrm{pg} / \\
\mathrm{ml}\end{array}$ & $\begin{array}{l}(\downarrow) 7.5 \text { and } \\
0.5 \text { fold } 1 \text { yr, } \\
2 \text { yr survival } \\
\text { in high }(\geq 17 \\
\text { pg/ml }) \text { vs. low } \\
(<17 \mathrm{pg} / \mathrm{ml}) \\
\text { FGF2 (p }= \\
0.0026) \\
\end{array}$ & Poor OS & [148] \\
\hline & $\begin{array}{l}184 \text { vs. } 100 \\
\text { controls }\end{array}$ & $\begin{array}{l}\text { Untreated } \\
\text { serum }\end{array}$ & $\begin{array}{l}\text { SCLC, } \\
\text { NSCLC }\end{array}$ & ELISA & $\begin{array}{l}(\uparrow) \text { FGF2 levels NSCLC median } \\
4.2 \mathrm{pg} / \mathrm{ml} \text {; SCLC median } 1.8 \mathrm{pg} / \\
\mathrm{ml} ;\end{array}$ & $\begin{array}{l}(\downarrow) \sim 0.5 \mathrm{mo} . \\
\text { survival in } \\
\text { high }(>3.4 \mathrm{pg} / \\
\text { ml) vs. low } \\
(<3.4 \mathrm{pg} / \mathrm{ml}) \\
\text { FGF2 (p= } \\
0.023) \\
\end{array}$ & $\begin{array}{l}\text { No correlation with } \\
\text { clinicopathological } \\
\text { parameters }\end{array}$ & [149] \\
\hline & $\begin{array}{l}40 \text { vs. } 22 \\
\text { controls }\end{array}$ & $\begin{array}{l}\text { Untreated } \\
\text { serum }\end{array}$ & NSCLC & ELISA & $\begin{array}{l}(\uparrow) 1.6 \text { fold FGF2 levels in tumors } \\
\text { vs. controls }(p=0.01)\end{array}$ & $\begin{array}{l}(\downarrow) \sim 0.5 \mathrm{mo} . \\
\text { survival in } \\
\text { high }(>11.21 \\
\text { pg/ml }) \text { vs. low } \\
(<11.21 \mathrm{pg} / \mathrm{ml}) \\
\text { FGF2 }\end{array}$ & $\begin{array}{l}\text { No correlation with } \\
\text { stage, TSP-2 concen- } \\
\text { tration }\end{array}$ & {$[150]$} \\
\hline Melanoma & \begin{tabular}{|l|}
76,43 nevi, \\
10 dysplastic \\
controls \\
\end{tabular} & Biopsy & NM, SSM & $\mathrm{IHC}$ & $\begin{array}{l}\text { Strong cytoplasmic expression in } \\
\text { malignant vs. nuclear staining in } \\
\text { benign nevi. }\end{array}$ & - & Stromal localization & {$[151]$} \\
\hline $\begin{array}{l}\text { Oral Squa- } \\
\text { mous Cell } \\
\text { Carcinoma }\end{array}$ & 61 & $\begin{array}{l}\text { Untreated } \\
\text { biopsy }\end{array}$ & SCC & $\mathrm{IHC}$ & $\begin{array}{l}\text { Positive FGF2 expression in } \\
\text { cancer cells }\end{array}$ & $\begin{array}{l}(\downarrow) \sim 0.5 \text { fold } \\
\text { survival in } \\
\text { FGF2 }(+) \text { vs. } \\
(-) \text { expression } \\
(\mathrm{p}<0.01) \\
\end{array}$ & $\begin{array}{l}\text { Poor differentiation, } \\
\text { mode of invasion, } \\
\text { lymph node metas- } \\
\text { tasis }\end{array}$ & {$[152]$} \\
\hline $\begin{array}{l}\text { Osteosar- } \\
\text { coma }\end{array}$ & 80 & $\begin{array}{l}\text { Surgical } \\
\text { and biopsy }\end{array}$ & $\begin{array}{l}\text { Intramedul- } \\
\text { lary }\end{array}$ & $\mathrm{IHC}$ & $\begin{array}{l}57.5 \% \text { tumors strong positive with } \\
\text { cytoplasmic and epithelium FGF2 } \\
\text { expression }\end{array}$ & $\begin{array}{l}(\downarrow) \sim 0.5 \text { fold } \\
\text { mo. OS in }(+) \\
\text { vs. }(-) \text { FGF2 } \\
(p<0 . .006)\end{array}$ & MVD & {$[153]$} \\
\hline \multirow{4}{*}{$\begin{array}{l}\text { Ovarian } \\
\text { Cancer }\end{array}$} & $\begin{array}{l}117 \text { tumors; } \\
54 \text { benign, } \\
42 \text { normal } \\
\text { ovaries }\end{array}$ & $\begin{array}{l}\text { Untreated } \\
\text { serum }\end{array}$ & - & \begin{tabular}{|l} 
Fluo- \\
rokine \\
MAP \\
mul- \\
tiplex \\
kits \\
\end{tabular} & $\begin{array}{l}(\uparrow) 1.6 \text { fold FGF2 levels in malig- } \\
\text { nant tumors vs. controls }\end{array}$ & $\begin{array}{l}\text { No significant } \\
\text { difference }\end{array}$ & PDGF-AA $(\mathrm{p}<0.001)$ & {$[154]$} \\
\hline & \multirow{3}{*}{$\begin{array}{l}39 \text { vs. } 11 \\
\text { controls }\end{array}$} & \multirow{3}{*}{$\begin{array}{l}\text { Untreated } \\
\text { surgical, } \\
\text { serum }\end{array}$} & \multirow{3}{*}{$\begin{array}{l}\text { Serous } \\
\text { endome- } \\
\text { trioid clear } \\
\text { cell mixed } \\
\text { Braner }\end{array}$} & RT-PCR & $\begin{array}{l}\text { FGF2 gene expression strong in } \\
\text { malignant vs. weak detection in } \\
\text { control }\end{array}$ & \multirow{3}{*}{-} & \multirow{3}{*}{-} & \multirow{3}{*}[155]{} \\
\hline & & & & $\mathrm{IHC}$ & $\begin{array}{l}\text { Strong positive in tumors vs. weak } \\
\text { staining in normal control }\end{array}$ & & & \\
\hline & & & & ELISA & $(\uparrow)$ in tumors vs. controls $(\mathrm{p}=0.04)$ & & & \\
\hline \multirow{3}{*}{$\begin{array}{l}\text { Pancreatic } \\
\text { Cancer }\end{array}$} & & & & $\begin{array}{l}\text { North- } \\
\text { ern blot }\end{array}$ & $\begin{array}{l}(\uparrow) \text { 9-fold in tumors vs. normal } \\
\text { controls }(\mathrm{p}<0.01)\end{array}$ & \multirow{2}{*}{$\begin{array}{l}(\downarrow) \sim 0.6 \text { fold } \\
\text { months OS in } \\
\text { positive vs. } \\
\text { negative FGF2 } \\
(\mathrm{P}<0.001)\end{array}$} & \multirow[b]{2}{*}{$\begin{array}{l}\text { Advanced tumor } \\
\text { stage }\end{array}$} & \multirow[b]{2}{*}[156]{} \\
\hline & $\begin{array}{l}78 \text { vs. } 16 \\
\text { controls }\end{array}$ & Surgical & - & $\mathrm{IHC}$ & $\begin{array}{l}\text { Intense staining in cytoplasm and } \\
\text { nucleus of cancer cells vs. weak } \\
\text { cytoplasmic staining in normal } \\
\text { controls }\end{array}$ & & & \\
\hline & 46 & $\begin{array}{l}\text { TMA } \\
\text { blocks }\end{array}$ & Ductal ACA & IF & $\begin{array}{l}\text { Cytoplasmic FGF2 expression in } \\
\text { tumors vs. nuclear expression in } \\
\text { myofibroblasts; }(\downarrow) \text { nuclear FGF2 } \\
\text { staining in tumors vs. positive in } \\
\text { stromal cells }(35 \%)(\mathrm{P}<0.0001)\end{array}$ & - & - & {$[157]$} \\
\hline
\end{tabular}




\begin{tabular}{|c|c|c|c|c|c|c|c|c|}
\hline \multirow{5}{*}{$\begin{array}{l}\text { Prostate } \\
\text { Cancer }\end{array}$} & \begin{tabular}{|l|}
55 vs. 32 \\
benign \\
controls
\end{tabular} & $\begin{array}{l}\text { Untreated } \\
\text { serum }\end{array}$ & - & ELISA & $\begin{array}{l}\text { ( } \uparrow) \text { 2-fold FGF2 in tumors vs. } \\
\text { control }(\mathrm{P}<0.0007)\end{array}$ & - & $\begin{array}{l}\text { No correlation with } \\
\text { clinical stage, Gleason } \\
\text { grade }\end{array}$ & {$[158]$} \\
\hline & \multirow{2}{*}{$\begin{array}{l}47 \quad(36 \\
\text { patients }+11 \\
\text { benign) vs. } \\
23 \text { controls }\end{array}$} & Serum & \multirow[b]{2}{*}{ - } & ELISA & $\begin{array}{l}(\uparrow) 5 \text { fold FGF2 levels in tumors } \\
\text { vs. control }(\mathrm{P}=0.0002)\end{array}$ & & \multirow[b]{2}{*}{$\begin{array}{l}\text { High } \\
(>100 \mathrm{ng} / \mathrm{ml})\end{array}$} & \multirow[b]{2}{*}{ [159] } \\
\hline & & $\begin{array}{l}\text { Tissue } \\
\text { sections }\end{array}$ & & IHC & $\begin{array}{l}\text { strong cytoplasmic expression } \\
\text { in carcinoma cells vs. negative } \\
\text { benign epithelia }\end{array}$ & & & \\
\hline & \multirow{2}{*}{$\begin{array}{l}31 \text { vs. } 11 \\
\text { controls }\end{array}$} & \multirow{2}{*}{ Resection } & \multirow[b]{2}{*}{ |- } & ELISA & $\begin{array}{l}(\uparrow) 2.5 \text { fold FGF2 levels in tumors } \\
\text { vs. control }(\mathrm{P}<0.005)\end{array}$ & \multirow{2}{*}{-} & \multirow{2}{*}{$\begin{array}{l}\text { No correlation with } \\
\text { Gleason score, } \\
\text { pathological stage }\end{array}$} & \multirow{2}{*}{ [160] } \\
\hline & & & & $\mathrm{IHC}$ & $\begin{array}{l}\text { Strong stromal and endothelial } \\
\text { staining (not epithelial) }\end{array}$ & & & \\
\hline $\begin{array}{l}\text { Renal } \\
\text { Cancer }\end{array}$ & $\mid \begin{array}{lr}206 & \text { vs. } \\
10 & \text { benign } \\
\text { controls }\end{array}$ & $\begin{array}{l}\text { Untreated } \\
\text { serum }\end{array}$ & - & ELISA & $\begin{array}{l}(\uparrow)>3 \text { fold FGF2 in tumors vs. } \\
\text { benign controls }(\mathrm{P}=0.03)\end{array}$ & $\begin{array}{l}(\downarrow) \text { OS in high } \\
(>3.0 \mathrm{pg} / \mathrm{ml}) \\
\text { vs. low FGF2 } \\
(<3.0 \mathrm{pg} / \mathrm{ml}) \\
\end{array}$ & $\begin{array}{l}\text { Tumor stage, tumor } \\
\text { grade }\end{array}$ & {$[161]$} \\
\hline $\begin{array}{l}\text { Testicular } \\
\text { Cancer }\end{array}$ & $\begin{array}{l}21 \text { vs. } 22 \\
\text { control }\end{array}$ & $\begin{array}{l}\text { Serum, } \\
\text { tumor } \\
\text { biopsy }\end{array}$ & - & ELISA & $\begin{array}{l}(\uparrow) \sim 7.3 \text { fold serum FGF2 levels } \\
\text { in tumors vs. control }(\mathrm{P}<0.001), \\
\text { positive expression in all tumor } \\
\text { biopsies }\end{array}$ & - & Tumor stage & {$[162]$} \\
\hline $\begin{array}{l}\text { Thyroid } \\
\text { Cancer }\end{array}$ & $\begin{array}{|lr|}35 \text { vs. } & 26 \\
\text { controls }\end{array}$ & $\begin{array}{l}\text { Untreated } \\
\text { serum }\end{array}$ & $\begin{array}{l}\text { Papillary } \\
\text { carcinomas }\end{array}$ & ELISA & $\begin{array}{l}(\uparrow) \sim 2 \text { fold serum FGF2 levels in } \\
\text { tumors vs. controls }(\mathrm{p}<0.05)\end{array}$ & - & - & {$[163]$} \\
\hline
\end{tabular}
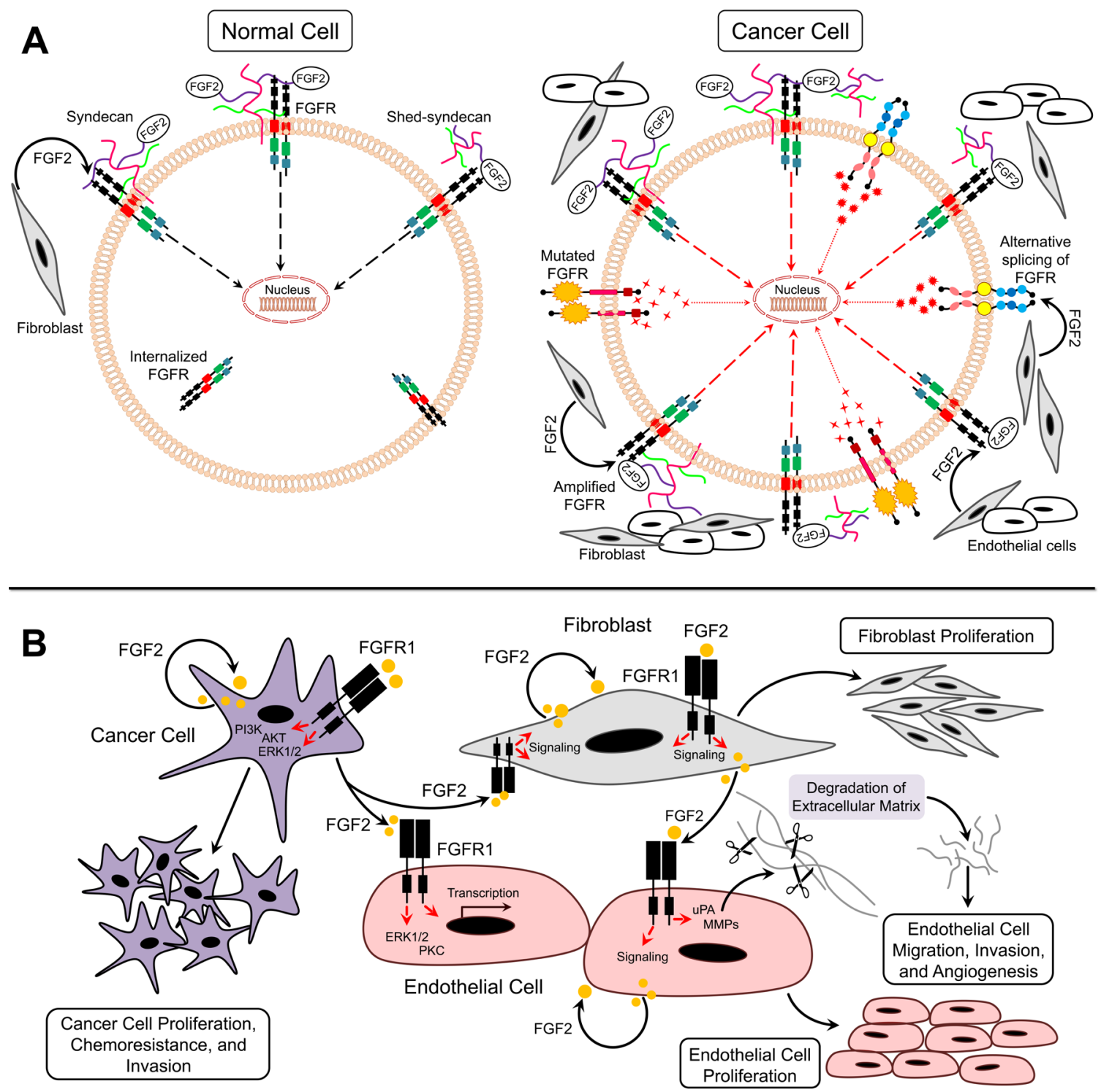

Figure 2: FGF2/FGFR signaling in cancer. A. Model for FGF2/FGFR function under normal and cancer conditions B. Paracrine and autocrine signaling of FGF2 in tumor microenvironment. 
Table 3: Studies evaluating FGF2 as a prognostic biomarker in cancer patients with hematological tumors.

\begin{tabular}{|c|c|c|c|c|c|c|}
\hline Cancer Type & \begin{tabular}{ll|}
$\begin{array}{l}\text { Patient } \\
\text { Number }\end{array}$ & Sample \\
\end{tabular} & Specimen Type & Method & FGF2 Expression Pattern & $\begin{array}{l}\text { Prognosis/ Associated } \\
\text { with }\end{array}$ & Ref \\
\hline \multirow{2}{*}{$\begin{array}{l}\text { Acute } \\
\text { Lymphoblastic } \\
\text { Leukemia } \\
\text { (ALL) }\end{array}$} & 28 vs. 11 controls & $\begin{array}{l}\text { Untreated, treated } \\
\text { plasma }\end{array}$ & ELISA & $\begin{array}{l}(\uparrow) \sim 1.4 \text { fold plasma FGF2 levels in } \\
\text { tumors vs. normal controls }\end{array}$ & - & {$[164]$} \\
\hline & $\begin{array}{l}22 \text { pediatric patients } \\
\text { vs. } 39 \text { controls } \\
\end{array}$ & Untreated urine & ELISA & $\begin{array}{l}(\uparrow) \sim 8 \text { fold urine FGF2 levels in tumors } \\
\text { vs. normal controls }(p<0.0001)\end{array}$ & - & {$[165]$} \\
\hline \multirow{2}{*}{$\begin{array}{l}\text { Acute Myeloid } \\
\text { Leukemia } \\
\text { (AML) }\end{array}$} & 113 vs. 11 controls & $\begin{array}{l}\text { Untreated, treated } \\
\text { plasma }\end{array}$ & ELISA & $\begin{array}{l}(\uparrow) 1.2 \text { fold plasma FGF2 levels in tumors } \\
\text { vs. normal controls }\end{array}$ & - & {$[164]$} \\
\hline & 81 vs. 18 controls & Untreated BM biopsy & $\mathrm{IHC}$ & $\begin{array}{l}(\uparrow) 1.6 \text { fold FGF2 levels in tumors vs. } \\
\text { normal controls }(\mathrm{p}=0.04)\end{array}$ & $\begin{array}{l}\text { No significant correlation } \\
\text { between FGF2 and MVD }\end{array}$ & {$[166]$} \\
\hline \multirow{4}{*}{$\begin{array}{l}\text { Chronic } \\
\text { Lymphocytic } \\
\text { Leukemia } \\
\text { (CLL) }\end{array}$} & 39 vs. 11 controls & \begin{tabular}{|lr}
$\begin{array}{l}\text { Treated, } \\
\text { peripheral }\end{array}$ & untreated \\
plasma & blood- \\
\end{tabular} & ELISA & $\begin{array}{l}(\uparrow) \text { FGF2 levels in } 54 \% \text { tumors vs. normal } \\
\text { range in healthy controls }\end{array}$ & - & [167] \\
\hline & 155 vs. 11 controls & $\begin{array}{l}\text { Untreated, treated } \\
\text { plasma }\end{array}$ & ELISA & $\begin{array}{l}(\uparrow) \sim 9 \text { fold plasma FGF2 levels in tumors } \\
\text { vs. normal controls }\end{array}$ & - & {$[164]$} \\
\hline & 14 vs. 58 controls & Urine & ELISA & $\begin{array}{l}(\uparrow) 2 \text { fold FGF2 levels in tumors vs. } \\
\text { controls }(\mathrm{P}=0.0001)\end{array}$ & - & [168] \\
\hline & 36 vs. 15 controls & $\begin{array}{l}\text { Peripheral blood (cell } \\
\text { lysates and plasma) }\end{array}$ & ELISA & $\begin{array}{l}(\uparrow) \sim 64 \text { fold FGF2 levels in tumors with } \\
\text { high risk vs. normal controls }(P<0.0001)\end{array}$ & $\begin{array}{l}\text { No significant correlation } \\
\text { between FGF2 and } \\
\text { factors other than stage } \\
\text { of disease }\end{array}$ & {$[169]$} \\
\hline \multirow{2}{*}{$\begin{array}{l}\text { Chronic } \\
\text { Myelogenous } \\
\text { Leukemia } \\
\text { (CML) }\end{array}$} & 16 vs. 11 controls & \begin{tabular}{|lr}
$\begin{array}{l}\text { Treated, } \\
\text { peripheral }\end{array}$ & $\begin{array}{r}\text { untreated } \\
\text { blood- }\end{array}$ \\
plasma & \\
\end{tabular} & ELISA & $\begin{array}{l}(\uparrow) \mathrm{FGF} 2 \text { levels in } 44 \% \text { tumors vs. normal } \\
\text { range in healthy controls }\end{array}$ & - & [167] \\
\hline & 53 vs. 11 controls & $\begin{array}{l}\text { Untreated, treated } \\
\text { plasma }\end{array}$ & ELISA & $\begin{array}{l}(\uparrow) 1.6 \text { fold plasma FGF2 levels in tumors } \\
\text { vs. normal controls }\end{array}$ & - & [164] \\
\hline $\begin{array}{l}\text { Hairy Cell } \\
\text { Leukemia } \\
\text { (HCL) }\end{array}$ & 7 vs. 7 controls & $\begin{array}{l}\text { Treated, untreated } \\
\text { serum and } \\
\text { aspirates }\end{array}$ & ELISA & $\begin{array}{l}\text { Serum- }(\uparrow) \sim 37 \text { fold FGF2 levels in } \\
\text { tumors vs. absent in controls }(\mathrm{p}<0.05) \text {; } \\
\text { BM aspirate: }(\uparrow) 16 \text { fold FGF2 levels in } \\
\text { tumors vs. absent in controls }(\mathrm{p}<0.001)\end{array}$ & - & [170] \\
\hline \multirow{4}{*}{$\begin{array}{l}\text { Hodgkin's } \\
\text { Lymphoma }\end{array}$} & 39 & Lymph nodes tissue & $\mathrm{IHC}$ & $85 \%$ tumors positive & - & [73] \\
\hline & 67 & TMA (NS) & RT-PCR & $\begin{array}{l}(\uparrow) 246 \text { fold FGF2 levels in PO tumors vs. } \\
\text { normal lymph node controls } \\
(\uparrow) 10 \text { fold FGF2 levels in GO tumors vs. } \\
\text { normal lymph node controls }\end{array}$ & \multirow{2}{*}{-} & \multirow[t]{2}{*}[62]{} \\
\hline & & & $\mathrm{IHC}$ & $\begin{array}{l}\text { Strong positive staining in PO patients } \\
\text { than GO patients }\end{array}$ & & \\
\hline & 37 & $\begin{array}{l}\text { Untreated, treated } \\
\text { serum }\end{array}$ & ELISA & $\begin{array}{l}\text { FGF2 levels in tumors were normal }(\mathrm{p}= \\
0.075)\end{array}$ & $\begin{array}{l}\text { No significant change in } \\
\text { FGF2 levels relative to } \\
\text { pre-therapy values }\end{array}$ & {$[171]$} \\
\hline \multirow{3}{*}{$\begin{array}{l}\text { Multiple } \\
\text { Myeloma }\end{array}$} & 18 vs. 4 controls & BM aspirates & RT-PCR & $\begin{array}{l}(\uparrow) \text { FGF2 expression in tumors }(13.5 \mathrm{pg} / \\
\mathrm{mL}) \text { vs. absent in controls }(\mathrm{P}=0.02)\end{array}$ & - & {$[70]$} \\
\hline & $\begin{array}{l}44 \text { and } 12 \text { anemia } \\
\text { patients }\end{array}$ & Plasma cells & ELISA & $\begin{array}{l}(\uparrow) 6.7 \text { fold FGF2 levels in active MM } \\
\text { patients vs. non-active ones }(\mathrm{p}<0.01)\end{array}$ & $\begin{array}{l}\text { No significant correlation } \\
\text { between FGF2 and BM } \\
\text { neovascularization } \\
\end{array}$ & {$[172]$} \\
\hline & 56 vs. 20 controls & $\begin{array}{l}\text { Untreated, treated } \\
\text { serum }\end{array}$ & ELISA & $\begin{array}{l}(\uparrow) \text { FGF2 levels in tumors vs. controls (p } \\
<0.001) \\
(\downarrow) 0.3 \text { fold FGF2 levels in treated } \\
\text { patients with CR vs. untreated patients } \\
(p<0.001)\end{array}$ & $\begin{array}{l}\text { Significant correlation } \\
\text { between FGF2, VEGF, } \\
\text { HGF, and B2M }\end{array}$ & {$[173]$} \\
\hline \multirow{4}{*}{$\begin{array}{l}\text { Non-Hodgkin's } \\
\text { Lymphoma }\end{array}$} & $\begin{array}{l}58 \text { untreated, } 19 \\
\text { treated, } 11 \text { controls }\end{array}$ & $\begin{array}{l}\text { Untreated, treated } \\
\text { serum }\end{array}$ & ELISA & $\begin{array}{l}(\uparrow) \sim 2 \text { fold serum FGF2 levels in tumors } \\
\text { vs. controls }(\mathrm{p}<0.001)-\text { No correlation } \\
\text { between FGF2 at diagnosis and after } \\
\text { treatment }\end{array}$ & $\begin{array}{l}\text { Correlated with bulky } \\
\text { disease }\end{array}$ & {$[174]$} \\
\hline & 39 & Biopsy & $\mathrm{IHC}$ & Positive expression in $23.1 \%$ tumors & $\begin{array}{l}(\downarrow) \quad 0.5 \text { and } 0.4 \text { fold } \\
\text { months OS (p=0.033) } \\
\text { and PFS (p=0.003), } \\
\text { respectively, in FGF2 } \\
\text { positive vs. negative } \\
\text { tumors; -correlated with } \\
\text { bulky disease } \\
\end{array}$ & [175] \\
\hline & 27 & BM biopsy & $\mathrm{IHC}$ & $7 \%$ positive FGF2 in tumors & - & [176] \\
\hline & 65 & $\begin{array}{l}\text { Untreated, treated } \\
\text { serum }\end{array}$ & ELISA & $\begin{array}{l}(\uparrow) \text { Untreated FGF2 in tumors vs. controls } \\
(\mathrm{p}<0.001)-\text { no significant change in } \\
\text { FGF2 relative to untreated sample values }\end{array}$ & - & [171] \\
\hline
\end{tabular}

BM: bone marrow; B2M: Beta-2 microglobulin; CR: complete remission; ELISA: the enzyme-linked immunosorbent assay; GO: good outcome; HGF- hepatocyte growth factor; IHC- immunohistochemistry; MM: multiple myeloma; MVD: microvessel density; NHL- NonHodgkin Lymphoma; NS: nodular sclerosis; OS: overall survival; PFS: progression free survival; Poor outcome; TMA: tissue microarray; VEGF: vascular endothelial growth factor. 
tyrosine kinase receptors [12]. The extracellular regions of these receptors contain three immunoglobulin (Ig)-like domains (designated as IgI, IgII, and IgIII) linked to the cytoplasmic domain via a transmembrane $\alpha$-helix (Figure 1A). FGFRs 1-3 can undergo alternative splicing during gene expression, and the IgIII domain is composed of an invariant IgIIIa exon alternatively spliced to IgIIIb or IgIIIc. The expression of IgIIIb and IgIIIc is important in defining FGF signaling specificity. While FGF1 binds to all FGFRs, FGF2 binds to FGFR1 (IIIb), FGFR1 (IIIc), FGFR2 (IIIc), and FGFR4 [2]. It has been reported that LMW FGF2 predominantly binds to FGFR1 (IIIc) and weakly to the other FGFRs [5, 13]. The cytoplasmic domain of FGFRs 1-4 contains a juxtamembrane split kinase domain, which contains tyrosine kinase motifs and a C-terminal tail [12]. Although FGFR5 lacks intracellular tyrosine kinase domain, this receptor can bind to multiple FGF ligands acting as a negative regulator of signaling [14].

FGF2 utilizes HSPGs, such as syndecans (SDC), as binding partners to stabilize the FGF-FGFR interaction and enhance resistance to proteolysis $[15,16]$. FGF2 cannot activate FGFRs in cells lacking heparan sulfate [17]. After the binding of FGF and HSPG to FGFR to form a ternary FGF:FGFR:HSPG complex, FGFRs dimerize leading to conformational changes in FGFR structure and subsequent intermolecular transphosphorylation of multiple cytoplasmic tyrosine residues (Figure 1A) [12, 18]. FGFR transmits extracellular signals to two main intracellular substrates, which are phospholipase C- $\gamma 1$ (PLC- $\gamma 1$ ) (also known as FRS1) and FGFR substrate 2 (also known as FRS2) (Figure 1A). The phosphorylation of FGFR1 tyrosine residues creates binding sites for $\mathrm{SH} 2$ domain of PLC- $\gamma$ required for phosphorylation and activation of PLC- $\gamma$. Conversely, FRS2 constitutively associates with the juxtamembrane region of the FGFR. The phosphorylation of FRS2 is essential for activation of the Ras-mitogen-activated protein kinase (MAPK) and phosphoinositide 3-kinase-Akt (PI3K-Akt) signaling pathways in cancer and endothelial cells (Figure 1A) [12, 19].

FGF2 also interacts with immobilized molecules bound to extracellular matrix (ECM), including cell membrane receptors and soluble molecules (Table 1, Figure 1B). The complex interactions between FGF2 and these molecules control bioavailability, stability, and concentration of FGF2 in the microenvironment [20]. FGF2 can tightly bind HSPG in ECM and is only released through the action of FGF-binding protein (FGF-BP), which is a critical controller of FGF bioavailability (Table 1, Figure 1B). In addition, the binding of FGF to heparin, released HSPG, or cell surface-bound HSPG also regulate FGF bioavailability and the interactions with FGFRs (Table 1, Figure 1B). Conversely, thrombospondin-1 (TSP-1) and pentraxin 3 (PTX3) prevent the interaction of FGF2 with cell surface HSPGs and FGFRs. Similarly;
xcFGFR1 (a soluble form of the extracellular portion of FGFR1) binds FGF2 and prevents FGF2/FGFR interaction (Table 1, Figure 1B).

Gangliosides are glycosphingolipids bound to cell membranes regulating growth of a wide variety of normal cells by binding to FGFs. Gangliosides are highly synthesized in metastatic tumors and are known to shed into the ECM. Integrins are transmembrane receptors that regulate the response to soluble FGF2 in endothelial cells. The interaction between $\alpha v \beta 3$ integrin and FGF2 promotes endothelial cell proliferation by activating the MAPK pathway [21]. In addition, the binding of fibrinogen to FGF2 requires $\alpha v \beta 3$ integrin to promote endothelial cell proliferation (Table 1, Figure 1B). These findings indicate that FGF2 bioactivity and interaction with FGFR is highly regulated by a complex network of interactions with various FGF2 binding partners.

\section{ROLES OF FGF2 IN TUMOR PROGRESSION}

Accumulating evidence suggests that FGF2/FGFR signaling is involved in several biological functions, such as embryonic development, tissue regeneration, wound repair, and normal hematopoiesis [1-3]. Expression of FGF2 and FGFRs in normal cells is highly regulated, and termination of FGF2 signaling is achieved through receptor internalization (Figure 2A) [1-3]. However, FGF2/FGFR signaling in cancer cells is dysregulated, which may contribute to the pathogenesis of many types of cancer (Figure 2A). Several studies have shown that FGF2 is a key tumor-promoting factor in the tumor microenvironment. The following section reviews current knowledge of the molecular pathways associated with FGF2 signaling in cancer, which represents a critical step for the implementation of strategies toward the development of personalized cancer therapy.

\section{Deregulation of FGFR signaling}

FGFR amplification and/or upregulation occur in cancer due to deregulated transcription or chromosomal amplification (Figure 2A) [22]. The upregulation of FGFR1 induces cellular transformation of nontransformed cells [23]. FGFR2 upregulation is associated with poor prognosis in patients of multiple cancer types [24]. Furthermore, FGFR2 amplification has been shown to be accompanied with C-terminal exon abrogation, which regulates receptor internalization [25]. Impaired termination of FGFR signaling leads to continuous receptor activation [22]. In addition, mutation of FGFR can also render it insensitive to endocytosis by maintaining its expression at the cell surface [22]. A number of germline activating point mutations of FGFRs have been identified in human cancers and are associated with poor 
survival and chemoresistance [26, 27]. Mutations in the extracellular domain of FGFRs facilitate ligand binding, while mutations in transmembrane and kinase domains lead to constitutive activation of receptors (Figure 2A) [22]. Furthermore, alternative splicing of the third Ig-like domain could promote tumorigenesis. Paracrine signaling typically occurs through FGFR-IIIb that is expressed on mesenchymal cells and -IIIc expressed on epithelial cells [22]. In cancer models, however, the switch from FGFR IIIb to FGFR IIIc by alternative splicing results in autocrine activation of the receptor (Figure 2A) [28]. For example, FGFR2-IIIb to IIIc switch is related to increased invasiveness in bladder and prostate cancers [29, 30]. In addition, FGFR1-IIIc has been upregulated in pancreatic cancer where it is regarded as a strong oncogene [31].

\section{FGF2 as pro-angiogenic agent}

FGF2 is an extremely potent pro-angiogenic growth factor. FGF2 exerts its effects on endothelial cells via a paracrine mode after being released by tumor and stromal cells or through mobilization from ECM (Figure 2B) [32]. In addition, FGF2 plays autocrine roles in endothelial cells [32]. It has been reported that endothelial cells predominantly express FGFR1 and to some extent FGFR2 [33, 34]. Activation of these receptors by FGF2 leads to endothelial cell proliferation, migration, protease production, and angiogenesis. Furthermore, the full mitogenic and chemotactic responses of FGF2 in endothelial cells require activation of ERK1/2 and protein kinase C (PKC) signaling pathways [35]. FGF2 upregulates plasmin-plasminogen activator (uPA) and matrix metalloproteinase (MMP) production in endothelial cells eventually leading to ECM degradation and angiogenesis [36]. In addition, the response of endothelial cells to FGF2 can be regulated by integrins [21]. Immobilized FGF2 binds to $\alpha v \beta 3$ integrin causing endothelial cell adhesion, migration, proliferation, and morphogenesis (Figure 2B) [37]. There is also considerable cross-talk between FGF and vascular endothelial growth factor (VEGF) signaling, whereby FGF-induced signaling promotes resistance to VEGF receptor signaling for blocking of the VEGF [38]. Moreover, transient expression of FGF2 in endothelial cells control the expression of genes implicated in cell cycle, differentiation, adhesion, and cell survival [39]. Taken together, these data suggest an important role of FGF2 in promoting endothelial cell angiogenesis (Figure 2B).

\section{FGF2 as mitogen for tumor cells}

Although FGF2 levels are elevated in several human cancers, FGF2 levels do not always correlate with microvessel density [40]. For example, in a study

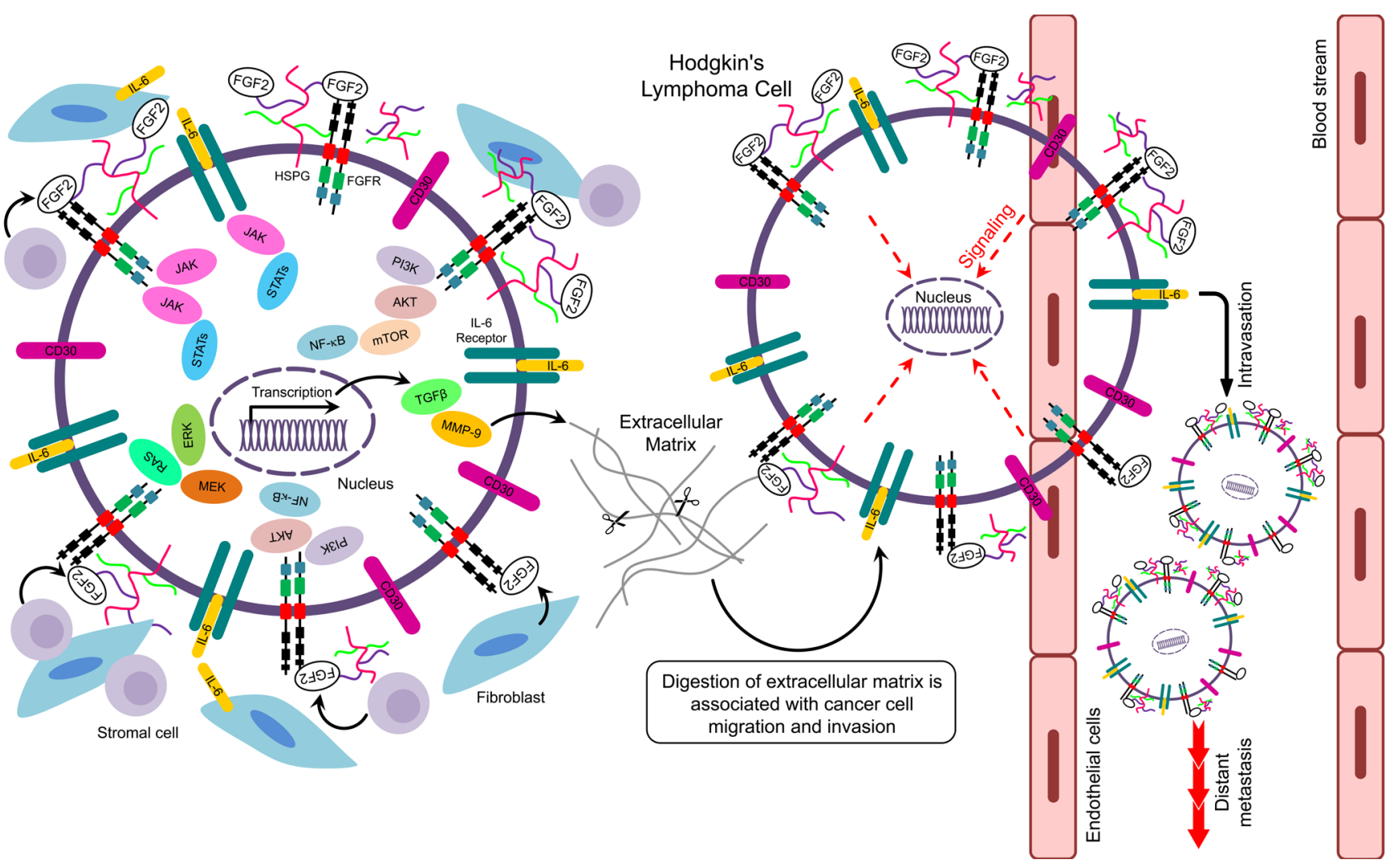

Figure 3: Putative signaling pathways related to FGF2 in Hodgkin's lymphoma. 
Table 4: In vitro diagnostics (IVD) and research use only (RUO) detection methods for FGF2.

\begin{tabular}{|c|c|c|c|c|c|c|}
\hline Diagnostic Type & \begin{tabular}{|l|}
$\begin{array}{l}\text { Source } \\
\text { (host) }\end{array}$ \\
\end{tabular} & Reactivity & Manufacturer & \begin{tabular}{|l|} 
Market \\
Status \\
\end{tabular} & Applications & Ref \\
\hline $\begin{array}{l}\text { Antibody } \\
\text { (Clone FGF288) }\end{array}$ & Mouse & $\begin{array}{l}\text { Unique synthetic peptide of } \\
\text { FGF2 coupled to keyhole limpet } \\
\text { hemocyanin }\end{array}$ & Biogenex (CA, USA) & Class I IVD & IHC & $*$ \\
\hline $\begin{array}{l}\text { Antibody } \\
\text { (Clone 3D9) }\end{array}$ & Mouse & $\begin{array}{l}\text { Recombinant } \\
\text { corresponding to amino acids 10-155 } \\
\text { human FGF2 }\end{array}$ & $\begin{array}{l}\text { Novus Biologicals (CO, USA); Enzo } \\
\text { Life Sciences (NY, USA) }\end{array}$ & RUO & WB, IF, IHC & $* *$ \\
\hline $\begin{array}{l}\text { Antibody } \\
\text { (Clone 10043) }\end{array}$ & Mouse & $\begin{array}{l}\text { Biotin conjugated; detects human } \\
\text { FGF2 in ELISA }\end{array}$ & $\begin{array}{l}\text { Novus Biologicals (CO, USA); } \\
\text { R\&D Systems (MN, USA) }\end{array}$ & RUO & ELISA & {$[177]$} \\
\hline $\begin{array}{l}\text { Antibody } \\
\text { (Clone 10060) }\end{array}$ & Mouse & Recognizes human FGF2 & Novus Biologicals (CO, USA) & RUO & ELISA & \begin{tabular}{|l}
177, \\
$178]$
\end{tabular} \\
\hline $\begin{array}{l}\text { Antibody } \\
\text { (Clone } \\
\text { 2H5G2C1) }\end{array}$ & Mouse & $\begin{array}{l}\text { Purified recombinant fragment of } \\
\text { human FGF2 }\end{array}$ & $\begin{array}{l}\text { Thermo Scientific (MA, USA); } \\
\text { Sigma-Aldrich (MO, USA) }\end{array}$ & RUO & WB, IHC & $* *$ \\
\hline $\begin{array}{l}\text { Antibody } \\
\text { (Clone FB-8) }\end{array}$ & Mouse & $\begin{array}{l}\text { Recombinant full length human } \\
\text { FGF2 }\end{array}$ & $\begin{array}{l}\text { Novus Biologicals (CO, USA); } \\
\text { Thermo Scientific (MA, USA) }\end{array}$ & RUO & WB, ELISA, RIA & {$[179]$} \\
\hline $\begin{array}{l}\begin{array}{l}\text { Antibody } \\
\text { (Clone } \\
\text { GF1) }\end{array} \\
\end{array}$ & Mouse & $\begin{array}{l}\text { Recombinant full length human } \\
\text { FGF2 }\end{array}$ & $\begin{array}{l}\text { Novus Biologicals (CO, USA); } \\
\text { LifeSpan Biosciences (WA, USA) }\end{array}$ & RUO & WB, ELISA, IHC & {$[180]$} \\
\hline $\begin{array}{l}\text { Antibody } \\
\text { (Clone AS24) }\end{array}$ & Mouse & Human FGF2 & $\begin{array}{l}\text { Santa Cruz (TX, USA); } \\
\text { Thermo Scientific (MA, USA) }\end{array}$ & RUO & IHC, ELISA & $* *$ \\
\hline $\begin{array}{l}\text { Antibody } \\
\text { (Clone AS25) }\end{array}$ & Mouse & Biotin Conjugated; Human FGF2 & $\begin{array}{l}\text { Abcam (UK); } \\
\text { Santa Cruz (TX, USA) }\end{array}$ & RUO & ELISA & $* *$ \\
\hline $\begin{array}{l}\text { Antibody } \\
\text { (Clone F-343) }\end{array}$ & Mouse & Full length native human FGF2 & $\begin{array}{l}\text { Abcam (UK); } \\
\text { Thermo Scientific (MA, USA) }\end{array}$ & RUO & ELISA, WB & $* *$ \\
\hline $\begin{array}{l}\text { Antibody } \\
\text { (Clone F-474) }\end{array}$ & Mouse & Full length native human FGF2 & $\begin{array}{l}\text { Abnova (Taiwan); } \\
\text { Abcam (UK) }\end{array}$ & RUO & ELISA & {$[181]$} \\
\hline $\begin{array}{l}\text { Antibody } \\
\text { (Clone F-74) }\end{array}$ & Mouse & Full length native human FGF2 & $\begin{array}{l}\text { Abnova (Taiwan); } \\
\text { Abcam (UK) }\end{array}$ & RUO & ELISA & $* *$ \\
\hline $\begin{array}{l}\text { Antibody } \\
\text { (Clone JKFb-1) }\end{array}$ & Mouse & Recombinant human FGF2 & Novus Biologicals (CO, USA); & RUO & ELISA & $* *$ \\
\hline $\begin{array}{l}\text { Antibody } \\
\text { (Clone bFM-1) }\end{array}$ & Mouse & Purified bovine brain FGF2 & EMD Millipore (MA, USA) & RUO & RIA & $\begin{array}{l}{[182,} \\
183]\end{array}$ \\
\hline $\begin{array}{l}\text { Antibody } \\
\text { (Clone bFM-2) }\end{array}$ & Mouse & Purified bovine brain FGF2 & EMD Millipore (MA, USA) & RUO & WB, IHC, RIA & $\begin{array}{l}{[184,} \\
185]\end{array}$ \\
\hline $\begin{array}{l}\text { Antibody } \\
\text { (Clone 17F4.1) }\end{array}$ & Mouse & Recombinant human FGF2 & EMD Millipore (MA, USA) & RUO & Neutralizing & $* *$ \\
\hline $\begin{array}{l}\text { Antibody } \\
\text { (Clone EP1735) }\end{array}$ & Rabbit & Synthetic human FGF2 & $\begin{array}{l}\text { Abcam (UK); } \\
\text { OriGene (MD, USA) }\end{array}$ & RUO & $\begin{array}{l}\text { WB, IP, FCM, } \\
\text { ELISA }\end{array}$ & $* *$ \\
\hline \begin{tabular}{l|} 
Antibody \\
(Clone \\
MM0276-6D38)
\end{tabular} & Mouse & Recombinant human FGF2 & $\begin{array}{l}\text { Novus Biologicals (CO, USA); } \\
\text { Abcam (UK) }\end{array}$ & RUO & WB & $* *$ \\
\hline $\begin{array}{l}\text { Antibody } \\
\text { (Clone NYR- } \\
\text { hFGF-b) }\end{array}$ & Mouse & Full length human FGF2 & Abcam (UK) & RUO & WB, IP, ELISA & $* *$ \\
\hline $\begin{array}{l}\text { Antibody } \\
\text { (Clone 0.T.50) }\end{array}$ & Mouse & Full length native bovine brain FGF2 & Abcam (UK) & RUO & Neutralizing & {$[186]$} \\
\hline
\end{tabular}

* = information taken by contacting company's technical department; ** = information taken from company's website

ELISA: enzyme-linked immunosorbent assay; FCM: flow cytometry; IF: immunofluorescence; IHC: immunohistochemistry; IP: immunoprecipitation; IVD: in vitro diagnostic; RIA: radioimmunoassay; RUO: research use only; WB: Western blot

conducted by Kuwahara et al, majority of pancreatic ductal carcinomas were positive for VEGF and FGF2 [41]. A significant correlation was observed between VEGF expression and MVD but not between FGF2 and MVD [41]. However, in a study conducted by Garcia de la Torre et al, FGF2 expression was high in primary parathyroid hyperplasia (PPH) and FGF2 scores and MVD were significantly correlated [42]. Therefore, FGF2 may contribute to cancer progression through alternative mechanisms involve acting directly on tumor cells [19]. Mutations in genes encoding FGFs and FGFRs deregulate FGFR signaling [43, 44]. However, no activating mutations have been reported as yet for FGF2 [44]. FGF2-induced activation of FGFR signaling and subsequent activation of PI3K/Akt and ERK1/2 signaling pathways in cancer cells $[19,45]$. FGF2 contributes to tumor progression through enhanced expression and/or release from tumor, endothelial, or stromal cells as well as release from local reservoirs in the ECM (Figure 2B) [43]. Secretion of proteases leads to release of the sequestered FGF2 [43]. Therefore, FGF2 functions in an autocrine or paracrine manner in cancer cells (Figure 2B). 
Table 5: Agents target FGF2/FGFR in cancer.

\begin{tabular}{|c|c|c|c|c|c|c|c|}
\hline Agent & Company & Target & Agent Type & Characteristics & Clinical Trial & $\begin{array}{l}\text { Indication/ } \\
\text { Tested on }\end{array}$ & Ref. \\
\hline \multicolumn{8}{|l|}{ FGF2 inhibitors } \\
\hline $\begin{array}{l}\text { FP-1039/ } \\
\text { GSK3052230 }\end{array}$ & $\begin{array}{l}\text { Five Prime } \\
\text { Pharmaceuticals (CA, } \\
\text { USA) }\end{array}$ & FGF2 & Protein & $\begin{array}{l}\text { Ligand trap: prevents FGF2 } \\
\text { from binding to receptors }\end{array}$ & $\begin{array}{l}\text { Phase I } \\
\text { (Ongoing) } \\
\text { NCT01868022 }\end{array}$ & \begin{tabular}{|l|} 
Squamous \\
non-small cell \\
lung cancer, \\
mesothelioma \\
\end{tabular} & {$[86]$} \\
\hline Interferon- $\alpha$ & - & FGF2 & Protein & $\begin{array}{l}\text { Inhibits FGF2 expression and } \\
\text { production }\end{array}$ & $\begin{array}{l}\text { Phase II } \\
\text { (ongoing) } \\
\text { NCT00049530 } \\
\end{array}$ & \begin{tabular}{|l|} 
Bladder \\
cancer, \\
melanoma \\
\end{tabular} & $\begin{array}{l}{[87} \\
187]\end{array}$ \\
\hline miRNA 646 & - & FGF2 & miRNA & Downregulates FGF2 & - & Osteosarcoma & [188] \\
\hline $\operatorname{Sm} 27$ & - & FGF2 & $\begin{array}{l}\text { Small } \\
\text { molecule }\end{array}$ & $\begin{array}{l}\text { Binds to heparin-binding site } \\
\text { on FGF2 and prevents FGF2 } \\
\text { interaction with receptors }\end{array}$ & - & $\begin{array}{l}\text { Endothelial } \\
\text { cells }\end{array}$ & {$[189]$} \\
\hline Anvirzel & $\begin{array}{l}\text { Nerium } \\
\text { Biotechnology } \\
\text { (Canada) }\end{array}$ & FGF2 & Glycoside & $\begin{array}{l}\text { Inhibits FGF2 export by } \\
\text { affecting } \mathrm{Na}+/ \mathrm{K}+\text { pump }\end{array}$ & - & $\begin{array}{l}\text { Prostate } \\
\text { cancer }\end{array}$ & {$[190]$} \\
\hline Pentraxin-3 & - & FGF2 & Protein & $\begin{array}{l}\text { Inhibits FGF2 binding to } \\
\text { FGFR }\end{array}$ & - & $\begin{array}{l}\text { Pancreatic } \\
\text { cancer }\end{array}$ & {$[191]$} \\
\hline $\begin{array}{l}\text { TNP-470/ } \\
\text { AGM-1470 }\end{array}$ & - & FGF2 & Antibiotic & $\begin{array}{l}\text { Suppresses expression and } \\
\text { production of FGF2 }\end{array}$ & - & Bladder cancer & {$[192]$} \\
\hline $\begin{array}{l}\text { Pentosan } \\
\text { Polysulfate } \\
\text { (Elmiron) } \\
\end{array}$ & $\begin{array}{l}\text { Ortho-McNeil } \\
\text { Pharmaceutical (NJ, } \\
\text { USA) }\end{array}$ & FGF2 & $\begin{array}{l}\text { Small } \\
\text { molecule }\end{array}$ & $\begin{array}{l}\text { Blocks and inhibits activity } \\
\text { of FGF2 }\end{array}$ & - & $\begin{array}{l}\text { Various } \\
\text { advanced } \\
\text { cancers } \\
\end{array}$ & {$[193]$} \\
\hline PI-88 & $\begin{array}{l}\text { Progen } \\
\text { Pharmaceuticals } \\
\text { (Australia) }\end{array}$ & FGF2 & $\begin{array}{l}\text { Small } \\
\text { molecule }\end{array}$ & $\begin{array}{l}\text { Binds and inhibits FGF2 } \\
\text { associated angiogenesis }\end{array}$ & - & Liver cancer & {$[194]$} \\
\hline Thalidomide & Celgene (NJ, USA) & FGF2 & $\begin{array}{l}\text { Small } \\
\text { molecule }\end{array}$ & $\begin{array}{l}\text { Inhibits FGF2 induced } \\
\text { angiogenesis }\end{array}$ & - & $\begin{array}{l}\text { Multiple } \\
\text { cancers }\end{array}$ & {$[195]$} \\
\hline $\begin{array}{l}\text { PAMPS, PAS, } \\
\text { PSS, PVS }\end{array}$ & - & FGF2 & $\begin{array}{l}\text { Sulfonic acid } \\
\text { polymers }\end{array}$ & FGF2 Antagonists & - & $\begin{array}{l}\text { Endothelial } \\
\text { cells }\end{array}$ & {$[196]$} \\
\hline $\begin{array}{l}\text { Sirolimus } \\
\text { (Rapamycin) }\end{array}$ & Pfizer (NY, USA) & FGF2 & $\begin{array}{l}\text { Small } \\
\text { molecule }\end{array}$ & $\begin{array}{l}\text { Inhibits FGF2 dependent } \\
\text { angiogenesis and proliferation }\end{array}$ & - & $\begin{array}{l}\text { Fibroblasts } \\
\text { and } \\
\text { endothelial } \\
\text { cells } \\
\end{array}$ & {$[197]$} \\
\hline $\begin{array}{l}\text { Suramin } \\
\text { (Germanin) }\end{array}$ & Bayer (Germany) & FGF2 & $\begin{array}{l}\text { Small } \\
\text { Molecule } \\
\end{array}$ & $\begin{array}{l}\text { FGF2 antagonist/ reduced } \\
\text { FGF2 expression }\end{array}$ & - & $\begin{array}{l}\text { Multiple } \\
\text { cancers }\end{array}$ & [198] \\
\hline Platelet Factor 4 & - & FGF2 & Protein & FGF2 antagonist & - & $\begin{array}{l}\text { Endothelial } \\
\text { cells }\end{array}$ & {$[199]$} \\
\hline \multicolumn{8}{|c|}{ Non-specific Tyrosine Kinase Inhibitors } \\
\hline $\begin{array}{l}\text { Lenvatinib } \\
\text { (Lenvima) }\end{array}$ & Eisai (Japan) & $\begin{array}{l}\text { FGFR1, PDGFR, } \\
\text { VEGFR }\end{array}$ & $\begin{array}{l}\text { Small } \\
\text { molecule }\end{array}$ & $\begin{array}{l}\text { Tyrosine kinase and } \\
\text { angiogenesis inhibitor }\end{array}$ & Approved & \begin{tabular}{|l|} 
Progressive, \\
radioactive \\
iodine- \\
refractory \\
thyroid cancer \\
\end{tabular} & {$[200]$} \\
\hline $\begin{array}{l}\text { AP } 24534 \\
\text { (Ponatinib, } \\
\text { Iclusig) } \\
\end{array}$ & $\begin{array}{l}\text { ARIAD } \\
\text { Pharmaceuticals } \\
\text { (MA, USA) }\end{array}$ & $\begin{array}{l}\text { BCR-ABL, FGFR1- } \\
4\end{array}$ & $\begin{array}{l}\text { Small } \\
\text { molecule }\end{array}$ & Tyrosine kinase inhibitor & Approved & CML, ALL & {$[89]$} \\
\hline $\begin{array}{l}\text { Pazopanib } \\
\text { (Votrient) }\end{array}$ & $\begin{array}{l}\text { GlaxoSmithKline } \\
\text { (England) }\end{array}$ & $\begin{array}{l}\text { FGFR, PDGFR, } \\
\text { VEGFR }\end{array}$ & $\begin{array}{l}\text { Small } \\
\text { molecule }\end{array}$ & $\begin{array}{l}\text { Tyrosine kinase and } \\
\text { angiogenesis inhibitor }\end{array}$ & Approved & $\begin{array}{l}\text { Renal cell } \\
\text { carcinoma, } \\
\text { soft tissue } \\
\text { sarcoma }\end{array}$ & {$[90]$} \\
\hline $\begin{array}{l}\text { Nintedanib } \\
\text { (Vargatef, Ofev) }\end{array}$ & $\begin{array}{l}\text { Boehringer Ingelheim } \\
\text { (Germany) }\end{array}$ & $\begin{array}{l}\text { FGFR1-3, PDGFR, } \\
\text { VEGFR }\end{array}$ & $\begin{array}{l}\text { Small } \\
\text { molecule }\end{array}$ & $\begin{array}{l}\text { Tyrosine kinase and } \\
\text { angiogenesis inhibitor }\end{array}$ & Approved (EU) & $\begin{array}{l}\text { Non-small-cell } \\
\text { lung cancer }\end{array}$ & {$[201]$} \\
\hline $\begin{array}{l}\text { BMS582664 } \\
\text { (Brivanib) }\end{array}$ & $\begin{array}{l}\text { Bristol-Myers Squibb } \\
\text { (NY, USA) }\end{array}$ & $\begin{array}{l}\text { FGFR1, } \\
\text { VEGFR1,VEGFR2 }\end{array}$ & $\begin{array}{l}\text { Small } \\
\text { molecule }\end{array}$ & $\begin{array}{l}\text { Tyrosine kinase and } \\
\text { angiogenesis inhibitor }\end{array}$ & $\begin{array}{lr}\text { Phase } & \mathrm{I} / \mathrm{II} / \\
\mathrm{III} & \text { trials } \\
\text { NCT00633789 } \\
\text { NCT00355238 } \\
\text { NCT00435669 } \\
\end{array}$ & $\begin{array}{l}\text { Liver cancer, } \\
\text { solid tumors }\end{array}$ & {$[202]$} \\
\hline $\begin{array}{l}\text { SU6668, TSU- } \\
68 \\
\text { (Orantinib) }\end{array}$ & $\begin{array}{l}\text { SUGEN/Pfizer/ } \\
\text { Taiho Pharmaceutical } \\
\text { (CA, USA/ NY, USA/ } \\
\text { Japan) }\end{array}$ & $\begin{array}{l}\text { FGFR, } \\
\text { VEGFR2 }\end{array}$ & $\begin{array}{l}\text { Small } \\
\text { molecule }\end{array}$ & $\begin{array}{l}\text { Tyrosine kinase and } \\
\text { angiogenesis inhibitor }\end{array}$ & $\begin{array}{l}\text { Phase I/II } \\
\text { NCT00024206 } \\
\text { NCT00784290 }\end{array}$ & $\begin{array}{l}\text { Advanced } \\
\text { solid tumors, } \\
\text { liver cancer }\end{array}$ & $\begin{array}{l}{[203} \\
204]\end{array}$ \\
\hline
\end{tabular}




\begin{tabular}{|c|c|c|c|c|c|c|c|}
\hline $\begin{array}{l}\text { TKI-258, } \\
\text { CHIR-258 } \\
\text { (Dovitinib) }\end{array}$ & $\begin{array}{l}\text { Novartis } \\
\text { (Switzerland) }\end{array}$ & $\begin{array}{l}\text { FGFR1-3, PDGFR, } \\
\text { VEGFR }\end{array}$ & $\begin{array}{l}\text { Small } \\
\text { molecule }\end{array}$ & $\begin{array}{l}\text { Tyrosine kinase and } \\
\text { angiogenesis inhibitor }\end{array}$ & $\begin{array}{l}\text { Phase II trials } \\
\text { NCT01058434 } \\
\text { NCT01831726 } \\
\text { NCT01861197 } \\
\text { NCT01732107 } \\
\text { NCT01719549 }\end{array}$ & $\begin{array}{l}\text { Multiple } \\
\text { cancers } \\
\text { including } \\
\text { relapsed MM, } \\
\text { non-small cell } \\
\text { lung cancer, } \\
\text { bladder } \\
\text { cancer, gastric } \\
\text { cancer }\end{array}$ & {$[205]$} \\
\hline $\begin{array}{l}\text { E3810 } \\
\text { (Lucitanib) }\end{array}$ & $\begin{array}{l}\text { EOS/ Clovis } \\
\text { Oncology (India/ CO, } \\
\text { USA) }\end{array}$ & FGFR1-3, VEGFR & $\begin{array}{l}\text { Small } \\
\text { molecule }\end{array}$ & Tyrosine kinase inhibitor & $\begin{array}{l}\text { PhaseI/II } \\
\text { NCT01283945 }\end{array}$ & Solid tumors & [206] \\
\hline \multicolumn{8}{|c|}{ Specific FGFR inhibitors } \\
\hline Debio 1347 & $\begin{array}{l}\text { Debiopharm } \\
\text { (Switzerland) }\end{array}$ & FGFR1-3 & $\begin{array}{l}\text { Small } \\
\text { molecule }\end{array}$ & $\begin{array}{ll}\text { Inhibits } & \text { FGFR } \\
\text { autophosphorylation } & \end{array}$ & $\begin{array}{l}\text { Phase I } \\
\text { NCT01948297 }\end{array}$ & $\begin{array}{l}\text { Advanced } \\
\text { solid tumors }\end{array}$ & {$[97]$} \\
\hline AZD 4547 & $\begin{array}{l}\text { AstraZeneca } \\
\text { (England) }\end{array}$ & FGFR1-3 & $\begin{array}{l}\text { Small } \\
\text { molecule }\end{array}$ & Tyrosine kinase inhibitor & $\begin{array}{l}\text { Phase II } \\
\text { NCT01795768 }\end{array}$ & $\begin{array}{l}\text { Gastric cancer, } \\
\text { esophageal } \\
\text { cancer, breast } \\
\text { cancer }\end{array}$ & {$[98]$} \\
\hline BGJ 398 & $\begin{array}{l}\text { Novartis } \\
\text { (Switzerland) }\end{array}$ & FGFR1-3 & $\begin{array}{l}\text { Small } \\
\text { molecule }\end{array}$ & $\begin{array}{l}\text { Tyrosine kinase and } \\
\text { angiogenesis inhibitor }\end{array}$ & $\begin{array}{l}\text { Phase I } \\
\text { NCT01004224 }\end{array}$ & $\begin{array}{l}\text { Advanced } \\
\text { solid tumors }\end{array}$ & {$[207]$} \\
\hline JNJ-42756493 & $\begin{array}{l}\text { Janssen Oncology } \\
\text { (Belgium) }\end{array}$ & FGFR & $\begin{array}{l}\text { Small } \\
\text { molecule }\end{array}$ & Tyrosine kinase inhibitor & $\begin{array}{l}\text { Phase I/II } \\
\text { NCT01703481 } \\
\text { NCT02365597 }\end{array}$ & $\begin{array}{l}\text { Urothelial } \\
\text { cancer, glioma }\end{array}$ & {$[208]$} \\
\hline ARQ 087 & Arqule (MA, USA) & FGFR & $\begin{array}{l}\text { Small } \\
\text { molecule }\end{array}$ & Tyrosine kinase inhibitor & $\begin{array}{l}\text { Phase I } \\
\text { NCT01752920 }\end{array}$ & Solid tumors & {$[209]$} \\
\hline LY287445 & $\begin{array}{l}\text { LKT Laboratories } \\
(\mathrm{MN}, \mathrm{USA})\end{array}$ & FGFR1-4 & $\begin{array}{l}\text { Small } \\
\text { molecule }\end{array}$ & Tyrosine kinase inhibitor & $\begin{array}{l}\text { Phase I } \\
\text { NCT01212107 }\end{array}$ & $\begin{array}{l}\text { Advanced } \\
\text { tumors }\end{array}$ & {$[210]$} \\
\hline TAS-120 & $\begin{array}{l}\text { Taiho } \\
\text { Pharmaceuticals } \\
\text { (Japan) }\end{array}$ & FGFR & $\begin{array}{l}\text { Small } \\
\text { molecule }\end{array}$ & Irreversible FGFR inhibitor & $\begin{array}{l}\text { Phase I/II } \\
\text { NCT02052778 }\end{array}$ & $\begin{array}{l}\text { Advanced } \\
\text { solid tumors, } \\
\text { multiple } \\
\text { myeloma } \\
\end{array}$ & {$[211]$} \\
\hline MFGR1877S & $\begin{array}{l}\text { Genentech/ } \\
\text { Roche (CA,USA/ } \\
\text { Switzerland) }\end{array}$ & FGFR3 & Antibody & $\begin{array}{l}\text { Inhibits FGFR3 mediated cell } \\
\text { proliferation }\end{array}$ & $\begin{array}{l}\text { Phase I } \\
\text { NCT01363024 } \\
\text { NCT01122875 }\end{array}$ & $\begin{array}{l}\text { Solid tumors, } \\
\text { multiple } \\
\text { myeloma }\end{array}$ & $\begin{array}{l}{[212,} \\
213]\end{array}$ \\
\hline BAY 1179470 & Bayer (NJ, USA) & FGFR2 & Antibody & $\begin{array}{l}\text { Inhibits FGFR2 mediated cell } \\
\text { proliferation }\end{array}$ & $\begin{array}{l}\text { Phase I } \\
\text { NCT01881217 }\end{array}$ & $\begin{array}{l}\text { Advanced, } \\
\text { refractory } \\
\text { solid tumors } \\
\end{array}$ & {$[100]$} \\
\hline PD 161570 & $\begin{array}{l}\text { Parke-Davis/Pfizer } \\
\text { (NY, USA) }\end{array}$ & FGFR & $\begin{array}{l}\text { Small } \\
\text { molecule }\end{array}$ & $\begin{array}{l}\text { Tyrosine kinase and receptor } \\
\text { phosphorylation inhibitor }\end{array}$ & - & $\begin{array}{l}\text { Ovarian } \\
\text { cancer }\end{array}$ & {$[214]$} \\
\hline PD 173074 & $\begin{array}{l}\text { Parke-Davis/Pfizer } \\
\text { (NY, USA) }\end{array}$ & FGFR & $\begin{array}{l}\text { Small } \\
\text { molecule }\end{array}$ & $\begin{array}{l}\text { Tyrosine kinase and } \\
\text { angiogenesis inhibitor }\end{array}$ & - & $\begin{array}{l}\text { Urothelial } \\
\text { carcinoma }\end{array}$ & {$[215]$} \\
\hline $\begin{array}{lr}\text { PD } & 166285 \\
\text { dihydrochloride }\end{array}$ & $\begin{array}{l}\text { Parke-Davis/Pfizer } \\
\text { (NY, USA) }\end{array}$ & FGFR & $\begin{array}{l}\text { Small } \\
\text { molecule }\end{array}$ & $\begin{array}{l}\text { Tyrosine kinase and } \\
\text { angiogenesis inhibitor }\end{array}$ & - & $\begin{array}{l}\text { Small cell } \\
\text { lung cancer }\end{array}$ & $\begin{array}{l}{[215} \\
216]\end{array}$ \\
\hline PD 166866 & $\begin{array}{l}\text { Parke-Davis/Pfizer } \\
\text { (NY, USA) }\end{array}$ & FGFR1 & $\begin{array}{l}\text { Small } \\
\text { molecule }\end{array}$ & $\begin{array}{l}\text { Tyrosine kinase and } \\
\text { angiogenesis inhibitor }\end{array}$ & - & $\begin{array}{l}\text { Small cell } \\
\text { lung cancer }\end{array}$ & $\begin{array}{l}{[217} \\
218]\end{array}$ \\
\hline $\begin{array}{l}\text { FIIN } \\
\text { hydrochloride }\end{array}$ & - & FGFR1-4 & $\begin{array}{l}\text { Small } \\
\text { molecule }\end{array}$ & Irreversible FGFR inhibitor & - & $\begin{array}{l}\text { Cancer cell } \\
\text { lines }\end{array}$ & {$[219]$} \\
\hline SU 5402 & - & FGFR, VEGFR & $\begin{array}{l}\text { Small } \\
\text { molecule }\end{array}$ & $\begin{array}{l}\text { Tyrosine kinase and } \\
\text { angiogenesis inhibitor }\end{array}$ & - & $\begin{array}{l}\text { Urothelial } \\
\text { carcinoma }\end{array}$ & [215] \\
\hline SSR128129E & - & FGFR & $\begin{array}{l}\text { Small } \\
\text { molecule }\end{array}$ & $\begin{array}{l}\text { Binds extracellular domain. } \\
\text { Inhibits FGFR signaling }\end{array}$ & - & $\begin{array}{l}\text { Endothelial } \\
\text { cells, cancer } \\
\text { cell lines }\end{array}$ & $\begin{array}{l}{[220,} \\
221]\end{array}$ \\
\hline
\end{tabular}


Table 6: Clinical trials related to FGF2/FGFR pathway.

\begin{tabular}{|c|c|c|c|c|c|c|}
\hline Clinical Trial Description ( Trial \#) & $\begin{array}{l}\text { Participants } \\
\#\end{array}$ & $\begin{array}{l}\text { Start Date/ } \\
\text { Trial Status }\end{array}$ & Originator & Sponsor & Mechanism of Action & $\begin{array}{l}\text { Study } \\
\text { Purpose }\end{array}$ \\
\hline \multicolumn{7}{|l|}{ FGF2 Inhibitors } \\
\hline $\begin{array}{l}\text { Phase II study of low dose Pegintron } \\
\text { (PEG interferon alfa-2b) in patients } \\
\text { with metastatic melanoma over- } \\
\text { expressing FGF2 (NCT00049530) }\end{array}$ & 32 & $\begin{array}{l}\text { Sept } 2003 \\
/ \quad \text { not } \\
\text { recruiting }- \\
\text { ongoing }\end{array}$ & $\begin{array}{l}\text { Enzon } \\
\text { Pharmaceuticals } \\
\text { (Piscataway, NJ) }\end{array}$ & $\begin{array}{l}\text { Eastern } \\
\text { Cooperative } \\
\text { Oncology Group } \\
\text { (Boston, MA) }\end{array}$ & $\begin{array}{l}\text { FGF2 } \\
\text { interferon } \\
\text { stimulant }\end{array}$ & $\begin{array}{l}\text { Interventional, } \\
\text { response level } \\
\text { of suppression } \\
\text { of plasma FGF2 } \\
\text { level with low dose } \\
\text { Pegintron }\end{array}$ \\
\hline $\begin{array}{l}\text { Phase I, open-label, dose-finding } \\
\text { study of FP-1039 } \\
\text { in advanced solid tumors } \\
\text { (NCT00687505) }\end{array}$ & 39 & $\begin{array}{l}\text { July } 2008 / \\
\text { completed }\end{array}$ & $\begin{array}{l}\text { Five Prime Thera } \\
\text { Francisco, CA) }\end{array}$ & apeutics, Inc. (San & FGFR1 inhibitor & $\begin{array}{l}\text { Interventional, } \\
\text { assess safety and } \\
\text { tolerability }\end{array}$ \\
\hline \multicolumn{7}{|l|}{ Non-Specific Tyrosine Kinase Inhibitors } \\
\hline $\begin{array}{l}\text { Phase I dose escalation study of } \\
\text { Lenvima (Lenvatinib) in patients } \\
\text { with solid tumors (NCT00280397) }\end{array}$ & 27 & $\begin{array}{l}\text { Jan } 2006- \\
\text { Nov } 2008 / \\
\text { completed }\end{array}$ & \multicolumn{2}{|l|}{ Eisai Inc. (Japan) } & $\begin{array}{l}\text { PDGFR-beta inhibitor; } \\
\text { c-kit inhibitor; FGFR } \\
\text { inhibitor; VEGFR 1-3 } \\
\text { inhibitor }\end{array}$ & $\begin{array}{l}\text { Interventional; } \\
\text { adverse events, } \\
\text { safety, tolerability }\end{array}$ \\
\hline $\begin{array}{l}\text { Phase Ib/II, open-label, multicenter } \\
\text { study of Lenvima (lenvatinib) } \\
\text { alone, and in combination with } \\
\text { Everolimus in subjects with } \\
\text { unresectable advanced or metastatic } \\
\text { renal cell carcinoma following one } \\
\text { prior VEGF-targeted treatment } \\
\text { (NCT01136733) }\end{array}$ & 180 & $\begin{array}{l}\text { Aug } \\
2010 \text { / not } \\
\text { recruiting - } \\
\text { ongoing }\end{array}$ & \multicolumn{2}{|c|}{ Eisai Co. Ltd. (Japan) } & $\begin{array}{l}\text { PDGFR-b antagonist; } \\
\text { VEGFR-2 antagonist, } \\
\text { FGFR inhibitor }\end{array}$ & $\begin{array}{l}\text { Interventional, assess } \\
\text { the dose-limiting } \\
\text { and maximally } \\
\text { tolerated toxicity, } \\
\text { recommended dose, } \\
\text { progression-free } \\
\text { survival }\end{array}$ \\
\hline $\begin{array}{l}\text { Phase II, multicenter, randomized, } \\
\text { open-label study of Votrient } \\
\text { (Pazopanib) in thyroid carcinoma } \\
\text { (NCT01813136) }\end{array}$ & 168 & $\begin{array}{l}\text { Mar } 2013 \\
\text { / ongoing - } \\
\text { recruiting }\end{array}$ & $\begin{array}{l}\text { Centre Leon } \\
\text { Berard (France) }\end{array}$ & $\begin{array}{l}\text { GlaxoSmithKline } \\
\text { (Philadelphia, PA) }\end{array}$ & $\begin{array}{l}\text { PDGFR antagonist; } \\
\text { BRAF inhibitor; c-kit } \\
\text { inhibitor; VEGFR 1-3 } \\
\text { antagonist }\end{array}$ & $\begin{array}{l}\text { Interventional, } \\
\text { efficacy (objective } \\
\text { response rate) }\end{array}$ \\
\hline $\begin{array}{l}\text { Phase I/II study of Orantinib for } \\
\text { advanced hepatocellular carcinoma } \\
\text { (NCT00784290) }\end{array}$ & 35 & $\begin{array}{l}\text { Sept } 2003 / \\
\text { completed }\end{array}$ & $\begin{array}{l}\text { Pfizer (New } \\
\text { York City, NY) }\end{array}$ & $\begin{array}{l}\text { Taiho } \\
\text { Pharmaceutical } \\
\text { Co., Ltd. (Japan) } \\
\end{array}$ & $\begin{array}{l}\text { FGF inhibitor; PDGF } \\
\text { inhibitor; VEGFR-2 } \\
\text { antagonist }\end{array}$ & $\begin{array}{l}\text { Interventional, } \\
\text { assess the safety and } \\
\text { response rate }\end{array}$ \\
\hline $\begin{array}{l}\text { Phase II study of Dovitinib in patients } \\
\text { with gastrointestinal stromal tumors } \\
\text { refractory and/or Intolerant to } \\
\text { Imatinib (NCT01478373) }\end{array}$ & 150 & $\begin{array}{l}\text { Jan } 2012- \\
\text { July } 2014 / \\
\text { completed }\end{array}$ & \multicolumn{2}{|c|}{ Novartis (East Hanover, NJ) } & $\begin{array}{l}\text { FGF2 inhibitor; } \\
\text { PDGFR B inhibitor; } \\
\text { VEGFR inhibitor }\end{array}$ & $\begin{array}{l}\text { Interventional, } \\
\text { measure safety and } \\
\text { efficacy }\end{array}$ \\
\hline $\begin{array}{l}\text { Phase II, open-label study of } \\
\text { Lucitanib in patients with FGFR1- } \\
\text { driven lung cancer (NCT02109016) }\end{array}$ & 40 & $\begin{array}{l}\text { Apr 2014/ } \\
\text { recruiting - } \\
\text { ongoing }\end{array}$ & $\begin{array}{l}\text { Advenchen } \\
\text { Laboratories } \\
\text { (Moorpark, CA) }\end{array}$ & $\begin{array}{l}\text { Clovis Oncology, } \\
\text { Inc. (Boulder, } \\
\text { CO) }\end{array}$ & $\begin{array}{l}\text { FGFR 1-3 inhibitor; } \\
\text { VEGFR1-3 inhibitor }\end{array}$ & $\begin{array}{l}\text { Interventional, } \\
\text { efficacy (objective } \\
\text { response rate) }\end{array}$ \\
\hline $\begin{array}{l}\text { Phase II study of Vargatef } \\
\text { (Nintedanib) in patients with } \\
\text { advanced } \text { FGFR3 } r \text { mutated, } \\
\text { overexpressed, or wild type urothelial } \\
\text { carcinoma of urinary bladder } \\
\text { (NCT02278978) }\end{array}$ & 129 & $\begin{array}{l}\text { Oct } \\
2014 / \text { not } \\
\text { recruiting - } \\
\text { ongoing }\end{array}$ & $\begin{array}{l}\text { Boehringer } \\
\text { Ingelheim } \\
\text { (Germany) }\end{array}$ & $\begin{array}{l}\text { National Taiwan } \\
\text { University } \\
\text { Hospital (Taiwan) }\end{array}$ & $\begin{array}{l}\text { PDGFR } \alpha-\beta \text { inhibitor; } \\
\text { FGFR } 1-3 \text { inhibitor; } \\
\text { VEGFR } 1-3 \text { inhibitor }\end{array}$ & $\begin{array}{l}\text { Interventional, safety } \\
\text { study with primary } \\
\text { purpose of treatment }\end{array}$ \\
\hline $\begin{array}{l}\text { Phase I/II, multicenter, randomized, } \\
\text { double-blind study of Vargatef } \\
\text { (Nintedanib) in combination with } \\
\text { paclitaxel for treatment of patients } \\
\text { with BRAF wild-type metastatic } \\
\text { melanoma (NCT02308553) }\end{array}$ & 126 & $\begin{array}{ll}\text { Jan } 2015 & / \\
\text { ongoing } & - \\
\text { recruiting } & \end{array}$ & $\begin{array}{l}\text { Boehringer } \\
\text { Ingelheim } \\
\text { (Ridgefield, CT) }\end{array}$ & $\begin{array}{l}\text { Prof. Dr.Dirk } \\
\text { Schadendorf } \\
\text { (Germany) }\end{array}$ & 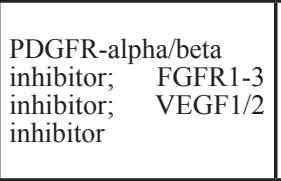 & $\begin{array}{l}\text { Interventional, } \\
\text { measure of } \\
\text { progression-free } \\
\text { survival, safety, } \\
\text { tolerability }\end{array}$ \\
\hline \multirow{3}{*}{$\begin{array}{l}\text { Phase III study to compare } \\
\text { efficacy and safety of Masitinib } \\
\text { in combination with Bortezomib } \\
\text { and Dexamethasone to placebo } \\
\text { in combination with Bortezomib } \\
\text { and Dexamethasone in patients } \\
\text { with relapsing multiple myeloma } \\
\text { (NCT01470131) }\end{array}$} & \multirow{3}{*}{300} & \multirow{3}{*}{ Apr 2013} & $\begin{array}{l}\text { Masitinib: } \mathrm{AB} \\
\text { Science (France) }\end{array}$ & \multirow{3}{*}{$\begin{array}{l}\text { Masitinib: } \quad \text { AB } \\
\text { Science (France) }\end{array}$} & $\begin{array}{l}\text { FGFR modulator; } \\
\text { PDGFR antagonist }\end{array}$ & \multirow{3}{*}{$\begin{array}{l}\text { Interventional, } \\
\text { assess overall time } \\
\text { to progression and } \\
\text { overall survival }\end{array}$} \\
\hline & & & $\begin{array}{l}\text { Bortezomib: } \\
\text { Millennium } \\
\text { Pharmaceuticals } \\
\text { (Cambridge, } \\
\text { MA) }\end{array}$ & & $\begin{array}{l}\text { Immunomodulator; } \\
\text { proteasome inhibitor }\end{array}$ & \\
\hline & & & $\begin{array}{l}\text { Dexamethasone: } \\
\text { Allergan } \\
\text { (Ireland) }\end{array}$ & & $\begin{array}{l}\text { Glucocorticoid } \\
\text { receptor agonist }\end{array}$ & \\
\hline \multicolumn{7}{|l|}{ FGFR Inhibitors } \\
\hline $\begin{array}{l}\text { Phase I, multicenter, open label study } \\
\text { of oral Debio } 1347 \text { (CH5183284) } \\
\text { in patients with advanced solid } \\
\text { malignancies, whose tumors have an } \\
\text { alteration of the FGFR } 1,2 \text { or } 3 \text { genes } \\
\text { (NCT01948297) }\end{array}$ & 112 & $\begin{array}{l}\text { Aug } 2013 \\
\text { / ongoing - } \\
\text { recruiting }\end{array}$ & \multicolumn{2}{|c|}{ Chugai Pharmaceutical (Japan) } & $\begin{array}{l}\text { Debiopharm } \\
\text { International } \\
\text { (Switzerland) }\end{array}$ & $\begin{array}{l}\text { Interventional, } \\
\text { measure of safety } \\
\text { and tolerability in } \\
\text { dose escalation study }\end{array}$ \\
\hline
\end{tabular}




\begin{tabular}{|c|c|c|c|c|c|}
\hline $\begin{array}{l}\text { Phase I, open-label, multicenter } \\
\text { study of AZD4547 in patients } \\
\text { with advanced solid tumors } \\
\text { (NCT00979134) }\end{array}$ & 979 & $\begin{array}{l}\text { Oct } 2009 \\
/ \quad \text { not } \\
\text { recruiting, } \\
\text { ongoing }\end{array}$ & AstraZeneca (England) & FGFR inhibitor & $\begin{array}{l}\text { Investigate the safety, } \\
\text { tolerability and } \\
\text { maximum tolerated } \\
\text { dose }\end{array}$ \\
\hline $\begin{array}{l}\text { Study of AZD } 4547 \text { in patients with } \\
\text { FGFR } 1 \text { or FGFR } 2 \text { amplified tumors } \\
\text { (NCT01795768) }\end{array}$ & 49 & $\begin{array}{l}\text { Sept } 2012 \\
\text { / ongoing - } \\
\text { recruiting }\end{array}$ & $\begin{array}{l}\text { Royal Marsden NHS Foundation } \\
\text { Trust (England) }\end{array}$ & FGFR inhibitor & $\begin{array}{l}\text { Interventional, assess } \\
\text { efficacy within } 8 \\
\text { weeks }\end{array}$ \\
\hline $\begin{array}{l}\text { Phase I, multi-center, open-label, } \\
\text { dose escalation study of oral BGJ398, } \\
\text { in adult patients with advanced solid } \\
\text { malignancies (NCT01004224) }\end{array}$ & 190 & $\begin{array}{l}\text { Dec } 2009 / \\
\text { ongoing - } \\
\text { recruiting }\end{array}$ & Novartis (East Hanover, NJ) & FGFR inhibitor & $\begin{array}{l}\text { Interventional, } \\
\text { safety, tolerability, } \\
\text { pharmacokinetics, } \\
\text { pharmacodynamics }\end{array}$ \\
\hline $\begin{array}{l}\text { Phase I study of JNJ-42756493 } \\
\text { in subjects with advanced or } \\
\text { refractory solid tumors or lymphoma } \\
(\text { NCT01703481) }\end{array}$ & 260 & $\begin{array}{l}\text { Jun } 2012 \text { / } \\
\text { ongoing - } \\
\text { recruiting }\end{array}$ & $\begin{array}{l}\text { Janssen Research } \\
\text { \& Development, } \\
\text { LLC (Belgium) }\end{array}$ & FGFR inhibitor & $\begin{array}{l}\text { Interventional, } \\
\text { safety, tolerability, } \\
\text { pharmacokinetics, } \\
\text { pharmacodynamics } \\
\end{array}$ \\
\hline $\begin{array}{l}\text { Phase I dose escalation study of ARQ } \\
087 \text { in adult subjects with advanced } \\
\text { solid tumors (NCT01752920) }\end{array}$ & 120 & $\begin{array}{l}\text { Dec } 2012 / \\
\text { ongoing - } \\
\text { recruiting }\end{array}$ & ArQule (Woburn, MA) & FGFR inhibitor & $\begin{array}{l}\text { Interventional, } \\
\text { measure of safety } \\
\text { and tolerability }\end{array}$ \\
\hline $\begin{array}{l}\text { Phase I study of LY2874455 in } \\
\text { patients with advanced cancer } \\
\text { (NCT01212107) }\end{array}$ & 94 & $\begin{array}{l}\text { Dec } 2010- \\
\text { Feb } 2015 / \\
\text { completed }\end{array}$ & $\begin{array}{l}\text { Eli Lilly and Company (Indianopolis, } \\
\text { IN) }\end{array}$ & FGFR inhibitor & $\begin{array}{l}\text { Interventional, } \\
\text { measure of safety } \\
\text { and tolerability }\end{array}$ \\
\hline $\begin{array}{l}\text { Phase I study of TAS-120 in patients } \\
\text { with advanced solid tumors with } \\
\text { or without FGF/FGFR-Related } \\
\text { abnormalities followed by a Phase II } \\
\text { study in patients with advanced solid } \\
\text { tumors or multiple myeloma with } \\
\text { FGF/FGFR-related abnormalities } \\
\text { (NCT02052778) }\end{array}$ & 835 & $\begin{array}{l}\text { July } 2014 \\
\text { / ongoing - } \\
\text { recruiting }\end{array}$ & Taiho Oncology, Inc. (Japan) & FGFR inhibitor & $\begin{array}{l}\text { Interventional, } \\
\text { measure of safety } \\
\text { and tolerability }\end{array}$ \\
\hline $\begin{array}{l}\text { Phase I, multicenter, open-label } \\
\text { study of MFGR } 1877 \mathrm{~S} \text { in patients } \\
\text { with relapsed or refractory multiple } \\
\text { myeloma (NCT01122875) }\end{array}$ & 14 & $\begin{array}{l}\text { Nov } 2010- \\
\text { May } 2012 \text { / } \\
\text { completed }\end{array}$ & $\begin{array}{l}\text { Genentech, Inc. (South San } \\
\text { Francisco, CA) }\end{array}$ & FGFR3 inhibitor & $\begin{array}{l}\text { Interventional, } \\
\text { measure of safety } \\
\text { and tolerability }\end{array}$ \\
\hline $\begin{array}{l}\text { Phase I, open-label, dose-escalation } \\
\text { study of BAY } 1179470 \text { in subjects } \\
\text { with advanced, refractory solid } \\
\text { tumors (NCT01881217) }\end{array}$ & 63 & $\begin{array}{l}\text { June } 2013 \text { / } \\
\text { recruiting - } \\
\text { ongoing }\end{array}$ & Bayer (Whippany, NJ) & FGFR2 inhibitor & $\begin{array}{l}\text { Interventional, } \\
\text { measure of safety, } \\
\text { tolerability, } \\
\text { pharmacokinetics, } \\
\text { and } \\
\text { pharmacodynamics }\end{array}$ \\
\hline
\end{tabular}

\section{FGF2 as mitogen for stromal cells}

Tumor progression to metastatic stage is promoted by fibroblasts in tumor stroma through secretion of multiple paracrine factors [46, 47]. FGF2 secreted by stromal fibroblasts induces tumor cell proliferation via FGFR paracrine signaling (Figures 2A, 2B) [48]. In addition, fibroblasts within tumor stroma can be activated by FGF2 secreted from endothelial and tumor cells (Figure 2B) [49]. Activated fibroblasts also produce proteases, such as MMPs that degrade ECM and promote secretion of growth factors including FGF2 in the tumor microenvironment [50].

\section{Dysregulated downstream FGF2/FGFR signaling pathway in hematological tumors}

Growing evidence supports a role of FGF2 in hematopoiesis starting at early stages of development through adulthood. In early stages of development, FGF2 has an important role in the proliferation of hemangioblasts, which are common progenitors of hematopoietic and endothelial cells [51] that play a central role in hematopoietic and angiogenic differentiation
[52]. In addition, FGF2 plays a role in self-renewal, cell survival, and cell adhesion of human embryonic stem cells [53]. In adult hematopoiesis, FGF2 induces proliferation of stromal cells of bone marrow [54]. FGF2 also induces the production of interleukin-6 (IL-6) [55] and counteracts the suppressive effect of transforming growth factor beta (TGF- $\beta$ ) on myeloid progenitor cells [56]. Myeloid precursor cells can be induced by FGF2 to give rise to erythroid progenitors [57]. In the absence of FGF2, myeloid progenitors generate cells of the neutrophilgranulocyte lineage upon FGF2 induction [58].

Neoplastic cells that define each hematological tumor are descendants of a specific lineage of the hematopoietic process. The involvement of FGF2 in various stages of hematopoiesis suggests that its dysregulation can result in hematological cancers [59]. FGFRs are expressed on all cell types of haematopoietic origin, and deregulation of FGFR gene expression or mutation has been observed in haematologic malignancies [59]. The ability of FGF2 to induce stem cell proliferation and differentiation implies that FGF2 is involved in very early stages of hematopoiesis. It has been reported that lymphoma cell lines express FGF2 and FGFRs and release FGF2 into culture media [45]. 


\section{Putative mechanisms of FGF2 in Hodgkin Lymphoma}

Hodgkin lymphoma (HL) is a rare B-cell malignant neoplasm characterized by a paucity of malignant Hodgkin and Reed-Sternberg cells (HRS cells) embedded within an inflammatory infiltrate [60]. FGF2 causes aberrant signaling activities in HRS cells involving SDC1, NF- $\kappa \mathrm{B}$, IL-6, Ras/ERK, and JAK/STAT as shown below.

SDC1 regulates bioavailability, dimerization, and interaction of FGF2 with FGFRs [20]. Witzig and colleagues reported that SDC1 was expressed in the bone marrow of patients with plasma cell proliferative disorders [61]. In line with this, increased expression of FGF2 and SDC1 was also reported in HL cell lines [68]. Overall, findings suggest that increased expression of FGF2, FGFR, and SCD1 is associated with poor prognosis and chemoresistance [62].

Activation of the $\mathrm{NF}-\kappa \mathrm{B}$ pathway is a wellestablished mechanism for protection of tumor cells from apoptosis $[63,64]$. In $\mathrm{HL}, \mathrm{NF}-\kappa \mathrm{B}$ is constitutively activated and represents an important step for the proliferation of neoplastic HRS cells (Figure 3) [65]. Epstein-Barr Virus (EBV) is a risk factor for HL [74]. In EBV-positive $(\mathrm{EBV}+) \mathrm{HL}$, the EBV oncoprotein, latent membrane protein-1 (LMP1), has been implicated in the activation of $\mathrm{NF}-\kappa \mathrm{B}$ signaling leading to enhanced $B-c e l l$ survival [65]. Alternatively, $N F-\kappa B$ may serve as a transcription factor for the FGF2 gene regulating expression and release of FGF2 by LMP1 [66, 67]. This process could be of clinical importance for determining the relationship between EBV status and FGF2 levels in HL patients (Figure 3). IL-1 $\beta$, which is expressed in subsets of cells in the HL tumor microenvironment, activates PI3K signaling pathway to upregulate FGF2 production through $\mathrm{NF}-\kappa \mathrm{B}[67]$.

The interleukin-6 (IL-6) signaling pathway has also been implicated in tumor progression [68, 69]. In multiple myeloma, stromal-derived IL-6 stimulates FGF2 expression in tumor cells, which in turn stimulates the secretion of IL-6 [70]. In addition, IL-6 and FGF2 together can enhance proliferation of myeloma cells [71]. In HL, IL-6 and its receptors are expressed by HRS cells (Figure 3) $[72,73]$. Moreover, IL-6 is upregulated in serum of HL patients resulting in poor prognosis [74]. FGF2 upregulates IL-6 gene expression in the fibroblast NIH$3 \mathrm{~T} 3$ cell line [75]. Moreover, in a basal cell carcinoma cell line, IL-6 mediates upregulation of FGF2 through activation of JAK/STAT3 and PI3K/Akt pathways which are aberrantly activated in HL [65]. Therefore, IL-6 and FGF2 may be involved in paracrine and autocrine interactions to promote chemoresistance in relapsed/

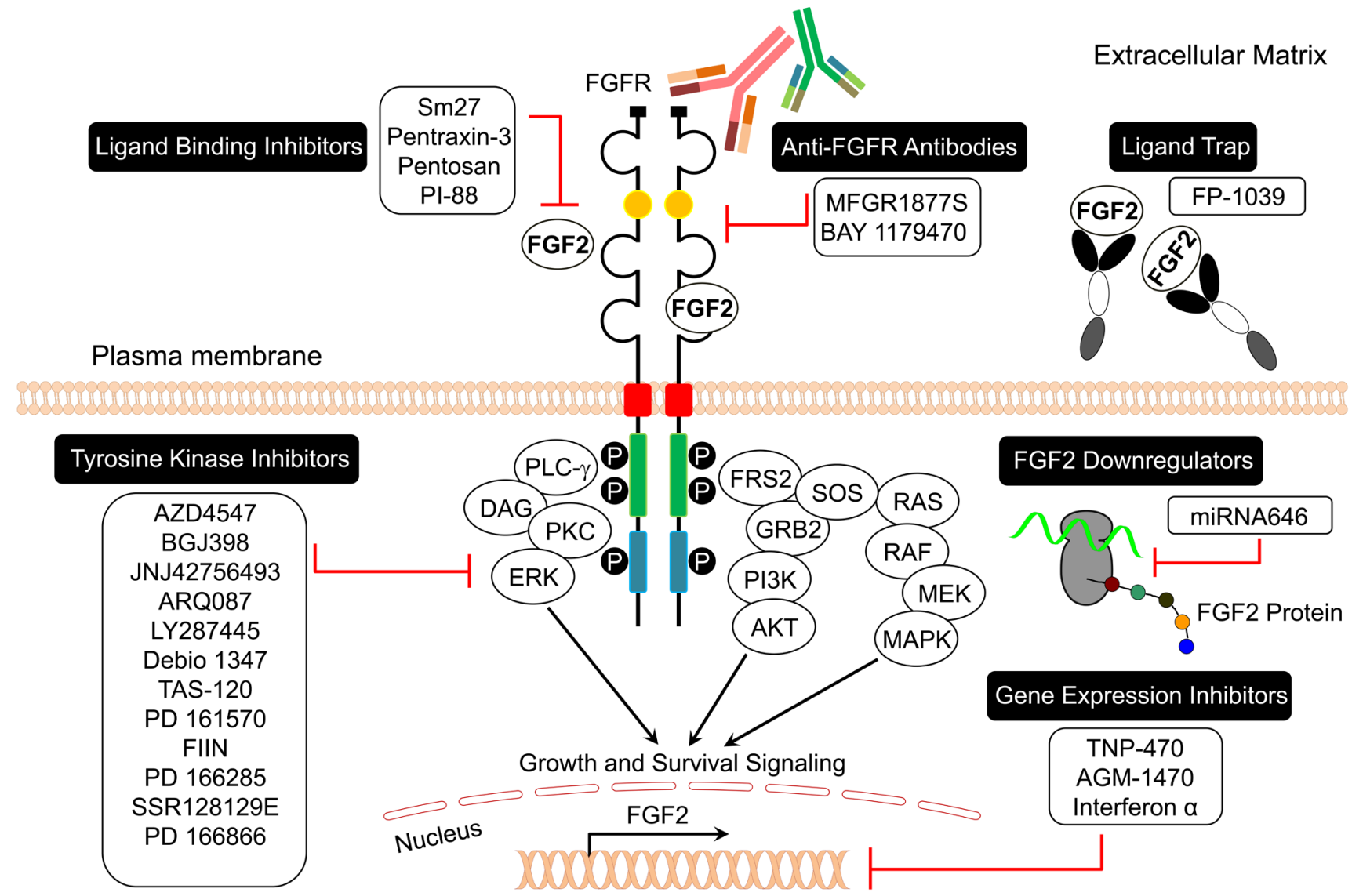

Figure 4: FGF2/FGFR signaling inhibitors in cancer. 
refractory HL.

Components of the Ras/ERK pathway are aberrantly expressed in malignancies and associated with chemoresistance [76]. MEK/ERK signaling pathway is essential for proliferation and survival of neoplastic HRS cells (Figure 3) [77]. FGF2 induces MEK signaling to upregulate anti-apoptotic proteins and enhance chemoresistance [78]. In addition, FGF2 mediates chemoresistance to doxorubicin in endothelial cells by inhibiting the pro-apoptotic protein ASK1, which is a member of the MEKK family [79].

The Janus kinase-signal transducer and activator of transcription (JAK/STAT) is a frequently altered pathway in the pathogenesis of HL [80]. The JAK/STAT pathway has been implicated in FGF2-induced chemoresistance in human cancer cells [81]. The JAK2 inhibitor lestaurtinib can overcome JAK/STAT-induced drug resistance in refractory HL cell lines [82]. Therefore, FGF2 may promote chemoresistance by deregulation of JAK/STAT signaling in HRS cells of relapsed and refractory HL patients (Figure 3).

The above studies demonstrated key downstream signaling pathways in HL, including cell growth, survival, and angiogenesis. It seems clear that the main pathways contributing to $\mathrm{HL}$ are regulated, at least in part, by FGF2 (Figure 3). Therefore, clinical trials using agents that target FGF pathway may be promising for treatment of HL.

\section{CLINICAL PROGNOSTIC VALUE AND FUNCTIONAL SIGNIFICANCE OF FGF2 IN SOLID AND HEMATOLOGICAL TUMORS}

Several studies have compared FGF2 serum levels in cancer patients to those in healthy volunteers (Tables 2 and 3). FGF2 expression in sera quantified by ELISA was strongly increased in cancer patients compared to healthy donors. Significant correlations between serum FGF2 levels and tumor stage, size, and metastasis were reported in endometrial, colorectal, esophageal, head and neck, liver, renal, and testicular cancers. However, no significant correlation was observed between increased serum FGF2 levels and tumor grade in bladder, breast, lung, and prostate cancers. In all leukemia and lymphoma studies, there was no correlation between increased serum levels of FGF2 and microvessel density or stage of the disease. However, high serum FGF2 levels were significantly correlated with tumor bulkiness in Non-Hodgkin's lymphoma (NHL). Therefore, the levels of serum FGF2 may have prognostic significance in these cancers, and quantification of FGF2 may provide an indirect, noninvasive way to monitor patients with high risk of relapse from solid and hematological tumors (Tables 2 and 3).

FGF2 expression in cancer surgical sections has been evaluated using immunohistochemical, Western blot, and qRT-PCR techniques (Tables 2 and 3). Upto-date diagnostics and antibodies that allow detection and precise quantification of FGF2 are listed in Table 4. Immunohistochemical and immunofluorescence studies have shown that FGF2 staining is heterogeneous and significantly increased in malignant tissues compared to benign or normal tissues (Tables 2 and 3). The differential expression and localization of FGF2 was also studied in different cancers. For example, FGF2 expression is generally limited to the cytoplasm of breast cancer tissues, while it is exclusively expressed in the nuclei of normal mammary tissues. Similarly, FGF2 is strongly expressed in the cytoplasm of malignant melanocytes and prostate cancer tissues, while it is almost entirely restricted to the nuclei of benign cells. In pancreatic cancer cells, FGF2 staining is intense in both the cytoplasm and nucleus, while it is weak in normal control tissues. Different expression and localization of FGF2 suggests that FGF2 and different members of FGFR may have different functions and signaling in various cancers. Moreover, FGF2 expression was elevated in tumor stroma, including inflammatory cells, myofibroblasts, and endothelial cells in colorectal, pancreatic, and prostate carcinomas, respectively (Table 2). These findings suggest that FGF2 can modulate tumor progression by activating signaling pathways in cancer-associated fibroblasts, endothelial cells, and cancer cells. In addition, fibroblasts that are abundant in the stroma of carcinomas at advanced stages of disease can mediate resistance to treatment via FGF2 secretion [83]. Additional studies on tissue sections have revealed that high FGF2 intratumoral levels are associated with advanced tumor stages of bladder, glioma, head and neck, liver, and prostate cancers (Table 2).

There is an urgent need for the identification of novel prognostic biomarkers to improve treatment of poor outcome cancer patients. It is worth noting that in the vast majority of studies, high serum and intratumoral FGF2 levels were associated with reduced cancer patient survival. In addition, high intratumoral and serum levels of FGF2 were associated with relapse and/or recurrence in various cancers such as bladder, breast, esophageal cancers and HL (Tables 2 and 3). In spite of a few contradictory finding, FGF2 is considered a significant tumor biomarker and a potential therapeutic target. Ongoing and future clinical trials are warranted to determine whether FGF2 could be incorporated in cancer prognosis and whether FGF targeting therapies have a favorable effect on cancer recurrence and mortality.

\section{TARGETING THE FGF2/FGFR PATHWAY IN CANCER}

The trend in cancer personalized medicine is to search for biomarkers to predict a patient's response to the targeted therapy and the emergence of secondary resistance [84]. High expression of FGF2 correlates with 
a worse survival for relapsed/refractory cancer patients (Tables 2 and 3). Therefore, targeting FGF signaling may provide opportunities for personalized therapy in those patients. Several FGF2/FGFR inhibitors have shown promising anticancer and antiangiogenic efficacy in several in vitro assays and in vivo preclinical animal models (Table 5, Figure 4). Clinical studies on these compounds have been conducted in the last decade to evaluate their safety, efficacy, and tolerability (Table 6). Ongoing clinical trials are recruiting patients with metastatic, advanced, or relapsed/ refractory cancers to evaluate the importance of blocking the FGF2/FGFR signaling in progressive and poor outcome cancer patients (Table 6).

It has been reported that various molecules can inhibit FGF2 (ligand) activity, binding, or expression in endothelial and tumor cells (Table 5, Figure 4). FGF ligand traps, such as FP-1039, block FGF2 interaction with FGFR (Tables 5 and 6, Figure 4) [85]. A phase I clinical trial was conducted to investigate the safety and tolerability of FP-1039 in advanced solid tumors (Table 6) [86]. FP-1039 is a soluble FGFR1 Fc fusion protein that was engineered to strongly bind all mitogenic FGF ligands. This compound showed promising results and inhibited FGF-mediated cell proliferation and angiogenesis in lung and endometrial cancer models [86]. AGM-1470, miRNA 646, and interferon alpha downregulate FGF2 expression in cancer cells (Table 5, Figure 4). A phase II clinical study was conducted to evaluate the efficacy of pegintron (peginterferon alpha-2b) in patients with stage IV metastatic melanoma overexpressing FGF2 (Table 6) [87]. The results showed that peginterferon alpha-2b suppressed FGF2 levels in $97 \%$ of patients with metastatic melanoma to reference range with a median progression free survival (PFS) and overall survival (OS) of 2.0 and 9.7 months, respectively (Table 6) [87].

Other FGF2 antagonists are under investigation for cell line and animal preclinical cancer models. Small molecules, such as sm27, pentosan, and PI-88 as well as proteins such as pentraxin-3 inhibit FGF2 binding to FGFRs (Table 5, Figure 4) [3]. The capability of FGF2 to bind heparin/heparan sulfate indicates that molecules able to interfere with this interaction may act as angiogenesis inhibitors. On this basis, compounds such as suramin, which mimic heparin, can interfere with FGF2 signaling (Table 5). Thalidomide, PAMPS, sirolimus, suramin, and platelet factor 4 inhibit FGF2-induced angiogenesis, while anvirzel inhibits FGF2 export via $\mathrm{Na}^{+} / \mathrm{K}^{+}$pumps (Table 5).

It has been reported that direct inhibition of FGFRs using small molecule inhibitors may be effective in cancer treatment. Several FGFR tyrosine kinase inhibitors (TKIs) are currently in early clinical development (Tables 5 and 6, Figure 4), and many of them exhibit dual specificity for FGFR and VEGFR due to similarity in the ATP binding pocket structure [85]. The first generation of inhibitors were developed as VEGFR and PDGFR inhibitors, but also can inhibit FGFR [88]. These compounds were successful in clinical trials and some of these drugs and drug combinations were subsequently approved by regulatory administrations worldwide for the treatment of different cancers (Tables 5 and 6).

Recently, the U.S. Food and Drug Administration (FDA) granted approval to Lenvima (lenvatinib, developed by Eisai) based on the results of a study on 392 patients with locally recurrent or metastatic, progressive, radioactive iodine-refractory differentiated thyroid cancer (DTC) who were randomly assigned to receive either Lenvima or a placebo. Study results showed that Lenvimatreated participants lived a median of 18.3 months (PFS) compared to a median of 3.6 months for participants who received placebo. Moreover, approximately two thirds of participants treated with Lenvima showed a reduction in tumor size compared to only two percent of participants who received placebo. Similarly, FDA recently approved Iclusig (ponatinib, developed by ARIAD Pharmaceuticals), which is a multi-tyrosine kinase inhibitor for the treatment of adult patients with chronic myeloid leukemia or acute lymphoblastic leukemia (Table 5) [89]. Moreover, the multi-tyrosine kinase inhibitor Votrient (pazopanib, developed by GlaxoSmithKline) was approved by FDA to treat patients with advanced renal cell cancer and patients with advanced soft tissue sarcoma who have received chemotherapy in the past (Tables 5 and 6) $[90]$.

Dovitinib (TKI-258, CHIR-258, developed by Novartis) is a potent VEGFR, PDGFR and FGFR inhibitor. Dovitinib showed promising anticancer and antiangiogenic activity against multiple myeloma and colon cancer models [91, 92]. A phase II trial was conducted to evaluate the safety and tolerability of Dovitinib in relapsed or refractory multiple myeloma patients, who are with or without $\mathrm{t}(4 ; 14)$ chromosomal translocation (Table 6$)$. The $\mathrm{t}(4 ; 14)$ translocation is observed in approximately 15 $20 \%$ of multiple myeloma patients, and it is associated with upregulation of FGFR3 and poor prognosis [93, 94]. Upregulation of FGFR3 occurs in nearly $70 \%$ of patients with the $\mathrm{t}(4 ; 14)$ translocation. Therefore, development of inhibitors such as Dovitinib may show promise in $\mathrm{t}(4 ; 14)$ multiple myeloma patients [94]. Further phase II clinical trials were conducted on Dovitinib for treatment of other types of cancers including lung, bladder and gastric cancers (Table 6).

Other investigational multi-kinase inhibitors, such as Brivanib, Orantinib, and Lucitanib, are currently progressing into phases II and III of clinical trials (Tables 5 and 6). Recent clinical trials have assessed the combination of a tyrosine kinase inhibitor with cytotoxic agents (Table 6). Combination strategies that involve the blockade of FGFR signaling with cytotoxic agents have the best clinical outcome for cancer treatment [85]. Recently, Vargatef (nintedanib, developed by Boehringer Ingelheim) was approved in the EU based on the results 
of a phase III study comparing Vargatef plus docetaxel to placebo plus docetaxel in patients with locally advanced/ metastatic non-small-cell lung carcinoma (NSCLC) after first-line therapy in over 1,300 patients in 27 countries [95]. Vargatef is an oral triple angiokinase inhibitor that simultaneously inhibits the VEGFR, PDGFR, and FGFR signaling pathways. The results indicated that treatment with Vargatef and docetaxel significantly extended the median overall survival from 10.3 to 12.6 months for patients with adenocarcinoma compared to placebo and docetaxel, with a quarter of patients surviving for two years or more with minimum side effects [95]. Several clinical trials are ongoing currently with compounds targeted for FGF2; a phase III study was designed to compare the safety and efficacy of a multi-tyrosine kinase inhibitor, masitinib, in combination with bortezomib and dexamethasone to placebo in combination with bortezomib and dexamethasone in patients with relapsing multiple myeloma. Masitinib is an orally active and bioavailable compound that is a weak inhibitor of FGFR3 [96].

More recently, second-generation inhibitors targeting FGFRs with high selectivity have been developed (Table 5, Figure 4). For example, Debio 1347, developed by Debiopharm Group, a Swiss-based global biopharmaceutical company, is an orally bioavailable inhibitor of FGFRs 1-3 that inhibits FGFR-mediated signal transduction pathways and consequently tumor cell proliferation and angiogenesis [97]. Debio 1347 will be used for personalized cancer treatment through the development of a companion diagnostic. It is currently being evaluated in Europe and the USA in a phase I trial to evaluate its safety and tolerability in patients with advanced solid tumors displaying alterations in FGFRs 1, 2, or 3 genes (Tables 5 and 6) [97]. Similarly, AZD4547, developed by AstraZeneca, is an orally tolerated inhibitor of FGFRs 1-3 [98]. AZD4547 inhibits FGFR kinase activity and tumor growth in vitro and in vivo [98]. This compound is currently being tested for safety and efficacy in different clinical trials against advanced tumors (Table 6). Other small molecule FGFR inhibitors, such as BGJ398, JNJ-42756493, ARQ 087, LY2874455, and TAS-120, are currently under clinical investigation for advanced, relapsed or refractory tumors and most of these trials are still recruiting patients (Tables 5 and 6). Other selective small molecule tyrosine kinase inhibitors, such as PD 161570, PD 173074, PD 166285 dihydrochloride, PD 166866, FIIN hydrochloride, SU 5402, and SSR128129E are currently being tested for their antitumor activity on cell lines and in vivo preclinical models (Table 5). Monoclonal antibodies specifically targeting particular FGFR isoforms are also being developed. MFGR1877S (developed by Genentech) is a human anti-FGFR3 monoclonal antibody that inhibits tumor progression of bladder carcinoma and multiple myeloma xenografts in mice by antagonizing FGFR3 signaling [99]. A phase I clinical trial was conducted to evaluate the response to MFGR1877S in patients with relapsed or refractory multiple myeloma (Tables 5 and 6). Similarly, BAY 1179470 (developed by Bayer) is a human anti-FGFR2 monoclonal antibody. BAY 1179470 showed antitumor activity in gastric cancer xenograft models with high FGFR2 expression [100]. The anti-FGFR2 antibody BAY 1179470 is currently in Phase I testing in subjects with advanced, refractory solid tumors (Tables 5 and 6)

\section{CONCLUSIONS}

FGF2 is frequently dysregulated in cancer, especially in advanced stages of disease. The upregulation of FGF2 or FGFRs can promote resistance to chemotherapy. FGF2 is currently being evaluated in clinical studies as a potential predictive biomarker for hematological and solid tumors. In addition, FGF2/FGFR inhibitors are being developed and evaluated as monotherapy or as part of a combination therapy for the treatment of different types of cancer. Identifying patients with advanced, relapsed or refractory cancers that would benefit from FGF2/FGFR signaling inhibition will allow for better treatment options of those patients in the era of personalized medicine.

\section{ACKNOWLEDGMENTS}

We thank Lisa B. Fishman Foundation and the John Theurer Cancer Center and Hackensack University Medical Center for supporting funds and preparation of this manuscript.

\section{CONFLICTS OF INTEREST}

There is no conflict of interest.

\section{REFERENCES}

1. Powers C, McLeskey S and Wellstein A. Fibroblast growth factors, their receptors and signaling. Endocr Relat Cancer. 2000; 7:165-197.

2. Korc M and Friesel RE. The role of fibroblast growth factors in tumor growth. Curr Cancer Drug Targets. 2009; 9:639.

3. Beenken A and Mohammadi M. The FGF family: biology, pathophysiology and therapy. Nat Rev Drug Discov. 2009; $8: 235-253$

4. Florkiewicz RZ and Sommer A. Human basic fibroblast growth factor gene encodes four polypeptides: three initiate translation from non-AUG codons. Proc Natl Acad Sci U S A. $1989 ; 86: 3978-3981$.

5. Ibrahimi OA, Zhang F, Eliseenkova AV, Linhardt RJ and Mohammadi M. Proline to arginine mutations in FGF receptors 1 and 3 result in Pfeiffer and Muenke craniosynostosis syndromes through enhancement of FGF binding affinity. Hum Mol Genet. 2004; 13:69-78. 
6. Florkiewicz RZ, Majack RA, Buechler RD and Florkiewicz E. Quantitative export of FGF-2 occurs through an alternative, energy-dependent, non-ER/Golgi pathway. J Cell Physiol. 1995; 162:388-399.

7. Ibrahimi OA, Zhang F, Hrstka SC, Mohammadi M and Linhardt RJ. Kinetic model for FGF, FGFR, and proteoglycan signal transduction complex assembly. Biochemistry (Mosc). 2004; 43:4724-4730.

8. Yu PJ, Ferrari G, Galloway AC, Mignatti P and Pintucci G. Basic fibroblast growth factor (FGF-2): the high molecular weight forms come of age. J Cell Biochem. 2007; 100:11001108.

9. Clarke WE, Berry M, Smith C, Kent A and Logan A. Coordination of fibroblast growth factor receptor 1 (FGFR1) and fibroblast growth factor-2 (FGF-2) trafficking to nuclei of reactive astrocytes around cerebral lesions in adult rats. Mol Cell Neurosci. 2001; 17:17-30.

10. Dunham-Ems SM, Lee Y-W, Stachowiak EK, Pudavar H, Claus P, Prasad PN and Stachowiak MK. Fibroblast growth factor receptor-1 (FGFR1) nuclear dynamics reveal a novel mechanism in transcription control. Mol Biol Cell. 2009; 20:2401-2412.

11. Peng H, Moffett J, Myers J, Fang X, Stachowiak EK, Maher P, Kratz E, Hines J, Fluharty SJ and Mizukoshi E. Novel nuclear signaling pathway mediates activation of fibroblast growth factor- 2 gene by type 1 and type 2 angiotensin II receptors. Molecular Biol Cell. 2001; 12:449-462.

12. Eswarakumar V, Lax I and Schlessinger J. Cellular signaling by fibroblast growth factor receptors. Cytokine Growth Factor Rev. 2005; 16:139-149.

13. Zhang $\mathrm{X}$, Ibrahimi OA, Olsen SK, Umemori $\mathrm{H}$, Mohammadi M and Ornitz DM. Receptor specificity of the fibroblast growth factor family. The complete mammalian FGF family. J Biol Chem. 2006; 281:15694-15700.

14. Turner $\mathrm{N}$ and Grose R. Fibroblast growth factor signalling: from development to cancer. Nat Rev Cancer. 2010; 10:116-129.

15. Goetz R and Mohammadi M. Exploring mechanisms of FGF signalling through the lens of structural biology. Nat Rev Mol Cell Biol. 2013; 14:166-180.

16. Akl M, Nagpal P, Ayoub N, Prabhu S, Gliksman M, Tai B, Hatipoglu A, Goy A and Suh K. Molecular and clinical profiles of syndecan-1 in solid and hematological cancer for prognosis and precision medicine. Oncotarget. 2015; 6:28693-715. doi: 10.18632/oncotarget.4981.

17. Ornitz D, Yayon A, Flanagan J, Svahn C, Levi E and Leder P. Heparin is required for cell-free binding of basic fibroblast growth factor to a soluble receptor and for mitogenesis in whole cells. Mol Cell Biol. 1992; 12:240247.

18. Lew ED, Furdui CM, Anderson KS and Schlessinger J. The precise sequence of FGF receptor autophosphorylation is kinetically driven and is disrupted by oncogenic mutations. Sci Signal. 2009; 2:ra6.
19. Karajannis MA, Vincent L, Direnzo R, Shmelkov SV, Zhang F, Feldman EJ, Bohlen P, Zhu Z, Sun H, Kussie $P$ and Rafii S. Activation of FGFRlbeta signaling pathway promotes survival, migration and resistance to chemotherapy in acute myeloid leukemia cells. Leukemia. 2006; 20:979-986.

20. Presta M, Dell'Era P, Mitola S, Moroni E, Ronca R and Rusnati M. Fibroblast growth factor/fibroblast growth factor receptor system in angiogenesis. Cytokine Growth Factor Rev. 2005; 16:159-178.

21. Eliceiri BP. Integrin and growth factor receptor crosstalk. Circ Res. 2001; 89:1104-1110.

22. Ahmad I, Iwata T and Leung HY. Mechanisms of FGFRmediated carcinogenesis. Biochim Biophys Acta. 2012; 4:850-860.

23. Behbod F, Xian W, Shaw CA, Hilsenbeck SG, Tsimelzon A and Rosen JM. Transcriptional profiling of mammary gland side population cells. Stem Cells. 2006; 24:1065-1074.

24. Jang JH, Shin KH and Park JG. Mutations in fibroblast growth factor receptor 2 and fibroblast growth factor receptor 3 genes associated with human gastric and colorectal cancers. Cancer Res. 2001; 61:3541-3543.

25. Cha JY, Maddileti S, Mitin N, Harden TK and Der CJ. Aberrant receptor internalization and enhanced FRS2dependent signaling contribute to the transforming activity of the fibroblast growth factor receptor $2 \mathrm{IIIb} \mathrm{C3}$ isoform. J Biol Chem. 2009; 284:6227-6240.

26. Taylor JGt, Cheuk AT, Tsang PS, Chung JY, Song YK, Desai K, Yu Y, Chen QR, Shah K, Youngblood V, Fang J, Kim SY, Yeung C, Helman LJ, Mendoza A, Ngo V, et al. Identification of FGFR4-activating mutations in human rhabdomyosarcomas that promote metastasis in xenotransplanted models. J Clin Invest. 2009; 119:33953407.

27. Thussbas C, Nahrig J, Streit S, Bange J, Kriner M, Kates R, Ulm K, Kiechle M, Hoefler H, Ullrich A and Harbeck N. FGFR4 Arg388 allele is associated with resistance to adjuvant therapy in primary breast cancer. J Clin Oncol. 2006; 24:3747-3755.

28. Savagner P, Valles AM, Jouanneau J, Yamada KM and Thiery JP. Alternative splicing in fibroblast growth factor receptor 2 is associated with induced epithelialmesenchymal transition in rat bladder carcinoma cells. Mol Biol Cell. 1994; 5:851-862.

29. Chaffer CL, Brennan JP, Slavin JL, Blick T, Thompson EW and Williams ED. Mesenchymal-to-epithelial transition facilitates bladder cancer metastasis: role of fibroblast growth factor receptor-2. Cancer Res. 2006; 66:1127111278 .

30. Matsubara A, Kan M, Feng S and McKeehan WL. Inhibition of growth of malignant rat prostate tumor cells by restoration of fibroblast growth factor receptor 2. Cancer Res. 1998; 58:1509-1514.

31. Kornmann M, Ishiwata T, Matsuda K, Lopez ME, Fukahi 
K, Asano G, Beger HG and Korc M. IIIc isoform of fibroblast growth factor receptor 1 is overexpressed in human pancreatic cancer and enhances tumorigenicity of hamster ductal cells. Gastroenterology. 2002; 123:301-313.

32. Gualandris A, Rusnati M, Belleri M, Nelli EE, Bastaki M, Molinari-Tosatti MP, Bonardi F, Parolini S, Albini A, Morbidelli L, Ziche M, Corallini A, Possati L, Vacca A, Ribatti D and Presta M. Basic fibroblast growth factor overexpression in endothelial cells: an autocrine mechanism for angiogenesis and angioproliferative diseases. Cell Growth Differ. 1996; 7:147-160.

33. Javerzat S, Auguste P and Bikfalvi A. The role of fibroblast growth factors in vascular development. Trends Mol Med. 2002; 8:483-489.

34. Dell'Era P, Belleri M, Stabile H, Massardi ML, Ribatti D and Presta M. Paracrine and autocrine effects of fibroblast growth factor-4 in endothelial cells. Oncogene. 2001; 20:2655-2663.

35. Presta M, Tiberio L, Rusnati M, Dell'Era P and Ragnotti $\mathrm{G}$. Basic fibroblast growth factor requires a long-lasting activation of protein kinase $\mathrm{C}$ to induce cell proliferation in transformed fetal bovine aortic endothelial cells. Cell Regul. 1991; 2:719-726.

36. Dell'Era P, Mohammadi M and Presta M. Different tyrosine autophosphorylation requirements in fibroblast growth factor receptor-1 mediate urokinase-type plasminogen activator induction and mitogenesis. Mol Biol Cell. 1999; 10:23-33.

37. Tanghetti E, Ria R, Dell'Era P, Urbinati C, Rusnati M, Ennas MG and Presta M. Biological activity of substratebound basic fibroblast growth factor (FGF2): recruitment of FGF receptor-1 in endothelial cell adhesion contacts. Oncogene. 2002; 21:3889-3897.

38. Casanovas O, Hicklin DJ, Bergers G and Hanahan D. Drug resistance by evasion of antiangiogenic targeting of VEGF signaling in late-stage pancreatic islet tumors. Cancer Cell. 2005; 8:299-309.

39. Dell'Era P, Coco L, Ronca R, Sennino B and Presta M. Gene expression profile in fibroblast growth factor 2-transformed endothelial cells. Oncogene. 2002; 21:24332440 .

40. Hoying JB and Williams SK. Effects of basic fibroblast growth factor on human microvessel endothelial cell migration on collagen I correlates inversely with adhesion and is cell density dependent. J Cell Physiol. 1996; 168:294304.

41. Kuwahara K, Sasaki T, Kuwada Y, Murakami M, Yamasaki $\mathrm{S}$ and Chayama K. Expressions of angiogenic factors in pancreatic ductal carcinoma: a correlative study with clinicopathologic parameters and patient survival. Pancreas. 2003 ; 26:344-349.

42. Garcia de la Torre N, Buley I, Wass JA, Jackson DG and Turner HE. Angiogenesis and lymphangiogenesis in parathyroid proliferative lesions. J Clin Endocrinol Metab. 2004; 89:2890-2896.

43. Haugsten EM, Wiedlocha A, Olsnes S and Wesche J. Roles of fibroblast growth factor receptors in carcinogenesis. Mol Cancer Res. 2010; 8:1439-1452.

44. Ribatti D, Vacca A, Rusnati M and Presta M. The discovery of basic fibroblast growth factor/fibroblast growth factor-2 and its role in haematological malignancies. Cytokine Growth Factor Rev. 2007; 18(3-4):327-334.

45. Krejci P, Faitova J, Laurell H, Hampl A and Dvorak P. FGF-2 expression and its action in human leukemia and lymphoma cell lines: Leukemia. 2003 Apr;17:818-20.).

46. Elenbaas B and Weinberg RA. Heterotypic signaling between epithelial tumor cells and fibroblasts in carcinoma formation. Exp Cell Res. 2001; 264:169-184.

47. Su G, Sung KE, Beebe DJ and Friedl A. Functional screen of paracrine signals in breast carcinoma fibroblasts. PLoS One. 2012; 7:8.

48. Gleave M, Hsieh JT, Gao CA, von Eschenbach AC and Chung LW. Acceleration of human prostate cancer growth in vivo by factors produced by prostate and bone fibroblasts. Cancer Res. 1991; 51:3753-3761.

49. Choi TH and Tseng SC. In vivo and in vitro demonstration of epithelial cell-induced myofibroblast differentiation of keratocytes and an inhibitory effect by amniotic membrane. Cornea. 2001; 20:197-204.

50. Rodemann HP and Muller GA. Characterization of human renal fibroblasts in health and disease: II. In vitro growth, differentiation, and collagen synthesis of fibroblasts from kidneys with interstitial fibrosis. Am J Kidney Dis. 1991; 17:684-686.

51. Kashiwakura I and Takahashi TA. Basic fibroblast growth factorstimulated ex vivo expansion of haematopoietic progenitor cells from human placental and umbilical cord blood. British journal of haematology. 2003; 122:479-488.

52. Pearson S, Sroczynska P, Lacaud G and Kouskoff V. The stepwise specification of embryonic stem cells to hematopoietic fate is driven by sequential exposure to Bmp4, activin A, bFGF and VEGF. Development. 2008; 135:1525-1535.

53. Eiselleova L, Matulka K, Kriz V, Kunova M, Schmidtova Z, Neradil J, Tichy B, Dvorakova D, Pospisilova S and Hampl A. A Complex Role for FGF2 in SelfRenewal, Survival, and Adhesion of Human Embryonic Stem Cells. Stem Cells. 2009; 27:1847-1857.

54. Yoon S-Y, Tefferi A and Li C-Y. Bone marrow stromal cell distribution of basic fibroblast growth factor in chronic myeloid disorders. Haematologica. 2001; 86:52-57.

55. Berardi AC, Wang A, Abraham J and Scadden DT. Basic fibroblast growth factor mediates its effects on committed myeloid progenitors by direct action and has no effect on hematopoietic stem cells. Blood. 1995; 86:2123-2129. 
56. Gabrilove J, Wong G, Bollenbacher E, White K, Kojima S and Wilson E. Basic fibroblast growth factor counteracts the suppressive effect of. Blood. 1993; 81(4).

57. Koritschoner NP, Bartunek P, Knespel S, Blendinger G and Zenke $\mathrm{M}$. The fibroblast growth factor receptor FGFR4 acts as a ligand dependent modulator of erythroid cell proliferation. Oncogene. 1999; 18:5904-5914.

58. Wilson EL, Rifkin DB, Kelly F, Hannocks M-J and Gabrilove JL. Basic fibroblast growth factor stimulates myelopoiesis in long-term human bone marrow cultures. Blood. 1991; 77:954-960.

59. Moroni E, Dell'Era P, Rusnati M and Presta M. Fibroblast growth factors and their receptors in hematopoiesis and hematological tumors. J Hematother Stem Cell Res. 2002; 11:19-32.

60. Fhu CW, Graham AM, Yap CT, Al-Salam S, Castella A, Chong SM and Lim YC. Reed-Sternberg cell-derived lymphotoxin-alpha activates endothelial cells to enhance T-cell recruitment in classical Hodgkin lymphoma. Blood. 2014; 124:2973-2982.

61. Witzig TE, Kimlinger T, Stenson $M$ and Therneau T. Syndecan-1 expression on malignant cells from the blood and marrow of patients with plasma cell proliferative disorders and B-cell chronic lymphocytic leukemia. Leuk Lymphoma. 1998; 31(1-2):167-175.

62. Gharbaran R, Goy A, Tanaka T, Park J, Kim C, Hasan N, Vemulapalli S, Sarojini S, Tuluc M, Nalley K, Bhattacharyya P, Pecora A and Suh KS. Fibroblast growth factor-2 (FGF2) and syndecan-1 (SDC1) are potential biomarkers for putative circulating CD15+/CD30+ cells in poor outcome Hodgkin lymphoma patients. Journal of hematology \& oncology. 2013; 6:1756-8722.

63. Panta GR, Kaur S, Cavin LG, Cortes ML, Mercurio F, Lothstein L, Sweatman TW, Israel M and Arsura M. ATM and the catalytic subunit of DNA-dependent protein kinase activate NF-kappaB through a common MEK/extracellular signal-regulated kinase/p90(rsk) signaling pathway in response to distinct forms of DNA damage. Mol Cell Biol. 2004; 24:1823-1835.

64. Rocha S, Martin AM, Meek DW and Perkins ND. p53 represses cyclin D1 transcription through down regulation of Bcl-3 and inducing increased association of the p52 NFkappaB subunit with histone deacetylase 1. Mol Cell Biol. 2003; 23:4713-4727.

65. Küppers R. The biology of Hodgkin's lymphoma. Nat Rev Cancer. 2009; 9:15-27.

66. Wakisaka N, Murono S, Yoshizaki T, Furukawa M and Pagano JS. Epstein-Barr virus latent membrane protein 1 induces and causes release of fibroblast growth factor-2. Cancer research. 2002; 62:6337-6344.

67. Lee JG and Kay EP. NF-B is the transcription factor for FGF-2 that causes endothelial mesenchymal transformation in cornea. Invest Ophthalmol Vis Sci. 2012; 53:1530-1538.

68. Hardin J, MacLeod S, Grigorieva I, Chang R, Barlogie
B, Xiao $\mathrm{H}$ and Epstein J. Interleukin-6 prevents dexamethasone-induced myeloma cell death. Blood. 1994; 84:3063-3070.

69. Lichtenstein A, Tu Y, Fady C, Vescio R and Berenson J. Interleukin-6 inhibits apoptosis of malignant plasma cells. Cell Immunol. 1995; 162:248-255.

70. Bisping G, Leo R, Wenning D, Dankbar B, Padró T, Kropff M, Scheffold C, Kröger M, Mesters RM and Berdel WE. Paracrine interactions of basic fibroblast growth factor and interleukin-6 in multiple myeloma. Blood. 2003; 101:27752783.

71. Ishikawa H, Tsuyama N, Liu S, Abroun S, Li F-J, Otsuyama K-i, Zheng X, Ma Z, Maki Y and Iqbal MS. Accelerated proliferation of myeloma cells by interleukin- 6 cooperating with fibroblast growth factor receptor 3-mediated signals. Oncogene. 2005; 24:6328-6332.

72. Reynolds GM, Billingham LJ, Gray LJ, Flavell JR, Najafipour S, Crocker J, Nelson P, Young LS and Murray PG. Interleukin 6 expression by Hodgkin/Reed-Sternberg cells is associated with the presence of 'B'symptoms and failure to achieve complete remission in patients with advanced Hodgkin's disease. Br J Haematol. 2002; 118:195-201.

73. Khnykin D, Troen G, Berner JM and Delabie J. The expression of fibroblast growth factors and their receptors in Hodgkin's lymphoma. J Pathol. 2006; 208:431-438.

74. Kurzrock R, Redman J, Cabanillas F, Jones D, Rothberg J and Talpaz M. Serum interleukin 6 levels are elevated in lymphoma patients and correlate with survival in advanced Hodgkin's disease and with B symptoms. Cancer research. 1993; 53:2118-2122.

75. Delrieu I, Arnaud E, Ferjoux G, Bayard F and Faye JC. Overexpression of the FGF-2 24-kDa isoform up-regulates IL-6 transcription in NIH-3T3 cells. FEBS letters. 1998; 436:17-22.

76. McCubrey J, Abrams S, Ligresti G, Misaghian N, Wong E, Steelman L, Bäsecke J, Troppmair J, Libra M and Nicoletti F. Involvement of p53 and Raf/MEK/ERK pathways in hematopoietic drug resistance. Leukemia. 2008; 22:20802090.

77. Zheng B, Fiumara P, Li YV, Georgakis G, Snell V, Younes M, Vauthey JN, Carbone A and Younes A. MEK/ERK pathway is aberrantly active in Hodgkin disease: a signaling pathway shared by CD30, CD40, and RANK that regulates cell proliferation and survival. Blood. 2003; 102:10191027.

78. Pardo OE, Arcaro A, Salerno G, Raguz S, Downward J and Seckl MJ. Fibroblast growth factor-2 induces translational regulation of Bcl-XL and Bcl-2 via a MEK-dependent pathway: correlation with resistance to etoposide-induced apoptosis. J Biol Chem. 2002; 277:12040-12046.

79. Alavi AS, Acevedo L, Min W and Cheresh DA. Chemoresistance of endothelial cells induced by basic fibroblast growth factor depends on Raf-1-mediated 
inhibition of the proapoptotic kinase, ASK1. Cancer Res. 2007; 67:2766-2772.

80. Joos S, Küpper M, Ohl S, von Bonin F, Mechtersheimer G, Bentz M, Marynen P, Möller P, Pfreundschuh M and Trümper L. Genomic imbalances including amplification of the tyrosine kinase gene JAK2 in CD30+ Hodgkin cells. Cancer Res. 2000; 60:549-552.

81. Carmo CR, Lyons-Lewis J, Seckl MJ and Costa-Pereira AP. A novel requirement for Janus kinases as mediators of drug resistance induced by fibroblast growth factor-2 in human cancer cells. PloS one. 2011; 6:e19861.

82. Diaz T, Navarro A, Ferrer G, Gel B, Gaya A, Artells R, Bellosillo B, Garcia-Garcia M, Serrano S and Martínez A. Lestaurtinib inhibition of the Jak/STAT signaling pathway in hodgkin lymphoma inhibits proliferation and induces apoptosis. PloS one. 2011; 6:e18856.

83. Pietras K, Pahler J, Bergers G and Hanahan D. Functions of paracrine PDGF signaling in the proangiogenic tumor stroma revealed by pharmacological targeting. PLoS Med. 2008; 5:0050019.

84. Tanase C, Codrici E, Popescu ID, Cruceru ML, Enciu A-M, Albulescu R, Ciubotaru V and Arsene D. Angiogenic markers: molecular targets for personalized medicine in pituitary adenoma. Personalized Med. 2013; 10:539-548.

85. Lieu C, Heymach J, Overman M, Tran H and Kopetz S. Beyond VEGF: inhibition of the fibroblast growth factor pathway and antiangiogenesis. Clin Cancer Res. 2011; 17:6130-6139.

86. Harding TC, Long L, Palencia S, Zhang H, Sadra A, Hestir K, Patil N, Levin A, Hsu AW, Charych D, Brennan T, Zanghi J, Halenbeck R, Marshall SA, Qin M, Doberstein $\mathrm{SK}$, et al. Blockade of nonhormonal fibroblast growth factors by FP-1039 inhibits growth of multiple types of cancer. Sci Transl Med. 2013; 5:3005414.

87. Go RS, Lee SJ, Shin D, Callister SM, Jobe DA, Conry RM, Tarhini AA and Kirkwood JM. ECOG phase II trial of graded-dose peginterferon alpha- $2 b$ in patients with metastatic melanoma overexpressing basic fibroblast growth factor (E2602). Clin Cancer Res. 2013; 19:65976604.

88. Jain VK and Turner NC. Challenges and opportunities in the targeting of fibroblast growth factor receptors in breast cancer. Breast Cancer Res. 2012; 14:208.

89. O'Hare T, Shakespeare WC, Zhu X, Eide CA, Rivera VM, Wang F, Adrian LT, Zhou T, Huang WS, Xu Q, Metcalf CA, 3rd, Tyner JW, Loriaux MM, Corbin AS, Wardwell S, Ning Y, et al. AP24534, a pan-BCR-ABL inhibitor for chronic myeloid leukemia, potently inhibits the T315I mutant and overcomes mutation-based resistance. Cancer Cell. 2009; 16:401-412.

90. Zivi A, Cerbone L, Recine F and Sternberg CN. Safety and tolerability of pazopanib in the treatment of renal cell carcinoma. Expert Opin Drug Saf. 2012; 11:851-859.

91. Kumar SK, Mikhael JR, Buadi FK, Dingli D, Dispenzieri
A, Fonseca R, Gertz MA, Greipp PR, Hayman SR and Kyle RA. (2009). Management of newly diagnosed symptomatic multiple myeloma: updated Mayo Stratification of Myeloma and Risk-Adapted Therapy (mSMART) consensus guidelines. Mayo Clin Proc: Elsevier), pp. 1095-1110.

92. Lee SH, de Menezes DL, Vora J, Harris A, Ye H, Nordahl L, Garrett E, Samara E, Aukerman SL and Gelb AB. In vivo target modulation and biological activity of CHIR-258, a multitargeted growth factor receptor kinase inhibitor, in colon cancer models. Clin Cancer Res. 2005; 11:3633-3641.

93. Moreau P, Facon T, Leleu X, Morineau N, Huyghe P, Harousseau J-L, Bataille R and Avet-Loiseau H. Recurrent $14 q 32$ translocations determine the prognosis of multiple myeloma, especially in patients receiving intensive chemotherapy. Blood. 2002; 100:1579-1583.

94. Kalff A and Spencer A. The t $(4 ; 14)$ translocation and FGFR3 overexpression in multiple myeloma: prognostic implications and current clinical strategies. Blood cancer journal. 2012; 2:e89.

95. Reck M, Kaiser R, Mellemgaard A, Douillard JY, Orlov S, Krzakowski M, von Pawel J, Gottfried M, Bondarenko I, Liao M, Gann CN, Barrueco J, Gaschler-Markefski B and Novello S. Docetaxel plus nintedanib versus docetaxel plus placebo in patients with previously treated non-smallcell lung cancer (LUME-Lung 1): a phase 3, double-blind, randomised controlled trial. Lancet Oncol. 2014; 15:143155.

96. Dubreuil P, Letard S, Ciufolini M, Gros L, Humbert M, Casteran N, Borge L, Hajem B, Lermet A, Sippl W, Voisset E, Arock M, Auclair C, Leventhal PS, Mansfield CD, Moussy A, et al. Masitinib (AB1010), a potent and selective tyrosine kinase inhibitor targeting KIT. PLoS One. 2009; 4:0007258.

97. Nakanishi Y, Akiyama N, Tsukaguchi T, Fujii T, Sakata K, Sase H, Isobe T, Morikami K, Shindoh H and Mio T. The fibroblast growth factor receptor genetic status as a potential predictor of the sensitivity to CH5183284/Debio 1347, a novel selective FGFR inhibitor. Mol Cancer Ther. 2014; 13:2547-2558.

98. Gavine PR, Mooney L, Kilgour E, Thomas AP, Al-Kadhimi K, Beck S, Rooney C, Coleman T, Baker D, Mellor MJ, Brooks AN and Klinowska T. AZD4547: an orally bioavailable, potent, and selective inhibitor of the fibroblast growth factor receptor tyrosine kinase family. Cancer Res. 2012; 72:2045-2056.

99. Qing J, Du X, Chen Y, Chan P, Li H, Wu P, Marsters S, Stawicki S, Tien J and Totpal K. Antibody-based targeting of FGFR3 in bladder carcinoma and $t$ (4; 14)-positive multiple myeloma in mice. The Journal of clinical investigation. 2009; 119:1216.

100. Schatz CA, Kopitz C, Wittemer-Rump S, Sommer A, Lindbom L, Osada M, Yamanouchi H, Huynh H, Krahn $\mathrm{T}$ and Asadullah K. Pharmacodynamic and stratification biomarker for the anti-FGFR2 antibody (BAY1179470) and the FGFR2-ADC. Cancer Res. 2014; 74(19 
Supplement):4766-4766.

101. Ornitz DM and Itoh N. Fibroblast growth factors. Genome Biol. 2001; 2:1-12.

102. Horowitz A, Tkachenko E and Simons M. Fibroblast growth factor-specific modulation of cellular response by syndecan-4. J Cell Biol. 2002; 157:715-725.

103. Rusnati M, Urbinati $C$ and Presta M. Internalization of basic fibroblast growth factor (bFGF) in cultured endothelial cells: Role of the low affinity heparinlike bFGF receptors. J Cell Physiol. 1993; 154:152-161.

104. Rusnati $M$ and Presta $M$. Interaction of angiogenic basic fibroblast growth factor with endothelial cell heparan sulfate proteoglycans. Int J Clin Lab Res. 1996; 26:15-23.

105. Rusnati M, Tanghetti E, Dell'Era P, Gualandris A and Presta M. v3 integrin mediates the cell-adhesive capacity and biological activity of basic fibroblast growth factor (FGF-2) in cultured endothelial cells. Mol Biol Cell. 1997; 8:2449-2461.

106. Rusnati M, Urbinati C, Tanghetti E, Dell'Era P, LortatJacob H and Presta M. Cell membrane GM1 ganglioside is a functional coreceptor for fibroblast growth factor 2. Proc Natl Acad Sci U S A. 2002; 99:4367-4372.

107. Hanneken A, Maher PA and Baird A. High affinity immunoreactive FGF receptors in the extracellular matrix of vascular endothelial cells - implications for the modulation of FGF-2. J Cell Biol. 1995; 128:1221-1228.

108. Bergonzoni L, Caccia P, Cletni O, Sarmientos $\mathrm{P}$ and Isacchi A. Characterization of a biologically active extracellular domain of fibroblast growth factor receptor 1 expressed in Escherichia coli. Eur J Biochem. 1992; 210:823-829.

109. Naumnik W, Ossolinska M, Plonska I, Chyczewska E and Niklinski J. Circulating Thrombospondin-2 and FGF-2 in Patients with Advanced Non-small Cell Lung Cancer: Correlation with Survival. Adv Exp Med Biol. 2015; 833:914.

110. Margosio B, Marchetti D, Vergani V, Giavazzi R, Rusnati M, Presta M and Taraboletti G. Thrombospondin 1 as a scavenger for matrix-associated fibroblast growth factor 2 . Blood. 2003; 102:4399-4406.

111. Rusnati M, Camozzi M, Moroni E, Bottazzi B, Peri G, Indraccolo S, Amadori A, Mantovani A and Presta M. Selective recognition of fibroblast growth factor-2 by the long pentraxin PTX3 inhibits angiogenesis. Blood. 2004; 104:92-99.

112. Sahni A, Baker CA, Sporn LA and Francis CW. Fibrinogen and fibrin protect fibroblast growth factor-2 from proteolytic degradation. Thromb Haemost. 2000; 83:736-741.

113. Sahni A and Francis CW. Plasmic degradation modulates activity of fibrinogen-bound fibroblast growth factor-2. J Thromb Haemost. 2003; 1:1271-1277.

114. Sauer H, Ravindran F, Beldoch M, Sharifpanah F, Jedelska J, Strehlow B and Wartenberg M. alpha2-Macroglobulin enhances vasculogenesis/angiogenesis of mouse embryonic stem cells by stimulation of nitric oxide generation and induction of fibroblast growth factor-2 expression. Stem Cells Dev. 2013; 22:1443-1454.

115. Nissen LJ, Cao R, Hedlund EM, Wang Z, Zhao X, Wetterskog D, Funa K, Brakenhielm E and Cao Y. Angiogenic factors FGF2 and PDGF-BB synergistically promote murine tumor neovascularization and metastasis. J Clin Invest. 2007; 117:2766-2777.

116. Sulpice E, Bryckaert M, Lacour J, Contreres JO and Tobelem G. Platelet factor 4 inhibits FGF2-induced endothelial cell proliferation via the extracellular signalregulated kinase pathway but not by the phosphatidylinositol 3-kinase pathway. Blood. 2002; 100:3087-3094.

117. Perollet C, Han ZC, Savona C, Caen JP and Bikfalvi A. Platelet factor 4 modulates fibroblast growth factor 2 (FGF2) activity and inhibits FGF-2 dimerization. Blood. 1998; 91:3289-3299.

118. Mignatti P, Mazzieri R and Rifkin DB. Expression of the urokinase receptor in vascular endothelial cells is stimulated by basic fibroblast growth factor. J Cell Biol. 1991; 113:1193-1201.

119. Spinetti G, Camarda G, Bernardini G, Romano Di Peppe $\mathrm{S}$, Capogrossi MC and Napolitano M. The chemokine CXCL13 (BCA-1) inhibits FGF-2 effects on endothelial cells. Biochem Biophys Res Commun. 2001; 289:19-24.

120. Andoh A, Bamba S, Fujino S, Inatomi O, Zhang Z, Kim S, Takayanagi A, Shimizu N and Fujiyama Y. Fibroblast growth factor-2 stimulates interleukin-6 secretion in human pancreatic periacinar myofibroblasts. Pancreas. 2004; 29:278-283.

121. Delrieu I, Arnaud E, Ferjoux G, Bayard F and Faye JC. Overexpression of the FGF-2 24-kDa isoform up-regulates IL-6 transcription in NIH-3T3 cells. FEBS Lett. 1998; 436:17-22.

122. Jee SH, Chu CY, Chiu HC, Huang YL, Tsai WL, Liao YH and Kuo ML. Interleukin-6 induced basic fibroblast growth factor-dependent angiogenesis in basal cell carcinoma cell line via JAK/STAT3 and PI3-kinase/Akt pathways. J Invest Dermatol. 2004; 123:1169-1175.

123. Lau M-T, So W-K and Leung PC. Fibroblast growth factor 2 induces E-cadherin down-regulation via PI3K/Akt/mTOR and MAPK/ERK signaling in ovarian cancer cells. PLoS One. 2013; 8:e59083.

124. Maloof P, Wang Q, Wang H, Stein D, Denny TN, Yahalom J, Fenig E and Wieder R. Overexpression of basic fibroblast growth factor (FGF-2) downregulates Bcl-2 and promotes apoptosis in MCF-7 human breast cancer cells. Breast Cancer Res Treat. 1999; 56:151-165.

125. Cao X-C, Zhang W-R, Cao W-F, Liu B-W, Zhang F, Zhao H-M, Meng R, Zhang L, Niu R-F and Hao X-S. Aquaporin3 is required for FGF-2-induced migration of human breast cancers. PLoS One. 2013; 8:e56735.

126. Bossard C, Laurell H, Van den Berghe L, Meunier S, Zanibellato $\mathrm{C}$ and Prats $\mathrm{H}$. Translokin is an intracellular mediator of FGF-2 trafficking. Nat Cell Biol. 2003; 5:433- 
439.

127. Yu P-J, Ferrari G, Pirelli L, Galloway AC, Mignatti P and Pintucci G. Thrombin cleaves the high molecular weight forms of basic fibroblast growth factor (FGF-2): a novel mechanism for the control of FGF-2 and thrombin activity. Oncogene. 2008; 27:2594-2601.

128. Tassi E, Al-Attar A, Aigner A, Swift MR, McDonnell K, Karavanov A and Wellstein A. Enhancement of fibroblast growth factor (FGF) activity by an FGF-binding protein. J Biol Chem. 2001; 276:40247-40253.

129. Gazzaniga P, Gandini O, Gradilone A, Silvestri I, Giuliani L, Magnanti M, Gallucci M, Saccani G, Frati L and Agliano A. Detection of basic fibroblast growth factor mRNA in urinary bladder cancer: correlation with local relapses. Int J Oncol. 1999; 14:1123-1130.

130. Szatmari T, Mundt F, Heidari-Hamedani G, Zong F, Ferolla E, Alexeyenko A, Hjerpe A and Dobra K. Novel genes and pathways modulated by syndecan-1: implications for the proliferation and cell-cycle regulation of malignant mesothelioma cells. PLoS One. 2012; 7:e48091.

131. Relf M, LeJeune S, Scott PA, Fox S, Smith K, Leek R, Moghaddam A, Whitehouse R, Bicknell R and Harris AL. Expression of the angiogenic factors vascular endothelial cell growth factor, acidic and basic fibroblast growth factor, tumor growth factor -1 , platelet-derived endothelial cell growth factor, placenta growth factor, and pleiotrophin in human primary breast cancer and its relation to angiogenesis. Cancer Res. 1997; 57:963-969.

132. Visscher D, DeMattia F, Ottosen S, Sarkar F and Crissman J. Biologic and clinical significance of basic fibroblast growth factor immunostaining in breast carcinoma. Mod Pathol. 1995; 8:665-670.

133. Granato AM, Nanni O, Falcini F, Folli S, Mosconi G, De Paola F, Medri L, Amadori D and Volpi A. Basic fibroblast growth factor and vascular endothelial growth factor serum levels in breast cancer patients and healthy women: useful as diagnostic tools. Breast Cancer Res. 2004; 6:R38-45.

134. Faridi A, Rudlowski C, Biesterfeld S, Schuh S, Rath W and Schröder W. Long-term follow-up and prognostic significance of angiogenic basic fibroblast growth factor (bFGF) expression in patients with breast cancer. Pathol Res Pract. 2002; 198:1-5.

135. Smith K, Fox S, Whitehouse R, Taylor M, Greenall M, Clarke $\mathrm{J}$ and Harris A. Upregulation of basic fibroblast growth factor in breast carcinoma and its relationship to vascular density, oestrogen receptor, epidermal growth factor receptor and survival. Ann Oncol. 1999; 10:707-713.

136. Hsiung R, Zhu W, Klein G, Qin W, Rosenberg A, Park P, Rosato E and Sauter E. High basic fibroblast growth factor levels in nipple aspirate fluid are correlated with breast cancer. Cancer J. 2002; 8:303-310.

137. Lee HJ, Seo AN, Park SY, Kim JY, Park JY, Yu JH, Ahn J-H and Gong G. Low Prognostic Implication of Fibroblast Growth Factor Family Activation in Triple-negative Breast
Cancer Subsets. Ann Surg Oncol. 2014; 21:1561-1568.

138. George M, Tutton M, Abulafi A, Eccles S and Swift R. Plasma basic fibroblast growth factor levels in colorectal cancer: a clinically useful assay? Clin Exp Metastasis. 2002; 19:735-738.

139. Xu C-J, Mikami T, Nakamura T, Tsuruta T, Nakada N, Yanagisawa N, Jiang S-X and Okayasu I. Tumor budding, myofibroblast proliferation, and fibrosis in obstructing colon carcinoma: The roles of Hsp47 and basic fibroblast growth factor. Pathol Res Pract. 2013; 209:69-74.

140. Dobrzycka B, Mackowiak-Matejczyk B, Kinalski M and Terlikowski SJ. Pretreatment serum levels of bFGF and VEGF and its clinical significance in endometrial carcinoma. Gynecol Oncol. 2013; 128:454-460.

141. Chen Y, Li X, Yang H, Xia Y, Guo L, Wu X, He C and $\mathrm{Lu}$ Y. Expression of basic fibroblast growth factor, CD31, and -smooth muscle actin and esophageal cancer recurrence after definitive chemoradiation. Tumour Biol. 2014; 35:7275-7282.

142. Takahashi JA, Fukumoto M, Igarashi K, Oda Y, Kikuchi $\mathrm{H}$ and Hatanaka M. Correlation of basic fibroblast growth factor expression levels with the degree of malignancy and vascularity in human gliomas. J Neurosurg. 1992; 76:792798.

143. Bian X-W, Du L-L, Shi J-Q, Cheng Y-S and Liu F-X. Correlation of bFGF, FGFR-1 and VEGF expression with vascularity and malignancy of human astrocytomas. Anal Quant Cytol Histol. 2000; 22:267-274.

144. Dellacono FR, Spiro J, Eisma R and Kreutzer D. Expression of basic fibroblast growth factor and its receptors by head and neck squamous carcinoma tumor and vascular endothelial cells. Am J Surg. 1997; 174:540-544.

145. Poon RT-P, Ng IO-L, Lau C, Yu W-C, Fan S-T and Wong J. Correlation of serum basic fibroblast growth factor levels with clinicopathologic features and postoperative recurrence in hepatocellular carcinoma. Am J Surg. 2001; 182:298-304.

146. Kin M, Sata M, Ueno T, Torimura T, Inuzuka S, Tsuji R, Sujaku K, Sakamoto M, Sugawara H and Tamaki S. Basic fibroblast growth factor regulates proliferation and motility of human hepatoma cells by an autocrine mechanism. J Hepatol. 1997; 27:677-687.

147. Ueno K, Inoue Y, Kawaguchi T, Hosoe S and Kawahara M. Increased serum levels of basic fibroblast growth factor in lung cancer patients: relevance to response of therapy and prognosis. Lung Cancer. 2001; 31:213-219.

148. Ruotsalainen T, Joensuu H, Mattson K and Salven P. High pretreatment serum concentration of basic fibroblast growth factor is a predictor of poor prognosis in small cell lung cancer. Cancer Epidemiol Biomarkers Prev. 2002; 11:14921495.

149. Joensuu H, Anttonen A, Eriksson M, Mäkitaro R, Alfthan H, Kinnula V and Leppä S. Soluble syndecan-1 and serum basic fibroblast growth factor are new prognostic factors in 
lung cancer. Cancer Res. 2002; 62:5210-5217.

150. Naumnik W, Ossoliska M, Poska I, Chyczewska E and Nikliski J. Circulating Thrombospondin-2 and FGF-2 in Patients with Advanced Non-small Cell Lung Cancer: Correlation with Survival. Adv Exp Med Biol. 2015; 833:914.

151. Fiuraskova M, Brychtova S, Sedlakova E, Benes P, Zalesak B, Hlobilkova A, Tichy M and Kolar Z. Molecular changes in PDEGF and bFGF in malignant melanomas in relation to the stromal microenvironment. Anticancer Res. 2005; 25(6B):4299-4303.

152. Hase T, Kawashiri S, Tanaka A, Nozaki S, Noguchi N, Kato K, Nakaya H and Nakagawa K. Correlation of basic fibroblast growth factor expression with the invasion and the prognosis of oral squamous cell carcinoma. J Oral Pathol Med. 2006; 35:136-139.

153. Ren T, Qing Y, Dai N, Li M, Qian C, Yang Y, Cheng Y, Li Z, Zhang S and Zhong Z. Apurinic/apyrimidinic endonuclease 1 induced upregulation of fibroblast growth factor 2 and its receptor 3 induces angiogenesis in human osteosarcoma cells. Cancer Sci. 2014; 105:186-194.

154. Madsen CV, Steffensen KD, Olsen DA, Waldstrøm M, SØGAARD CH, Brandslund I and Jakobsen A. Serum platelet-derived growth factor and fibroblast growth factor in patients with benign and malignant ovarian tumors. Anticancer Res. 2012; 32:3817-3825.

155. Le Page C, Ouellet V, Madore J, Hudson TJ, Tonin PN, Provencher DM and MesMasson AM. From gene profiling to diagnostic markers: IL18 and FGF2 complement CA125 as serumbased markers in epithelial ovarian cancer. Int $\mathrm{J}$ Cancer. 2006; 118:1750-1758.

156. Yamanaka Y, Friess H, Buchler M, Beger HG, Uchida E, Onda M, Kobrin MS and Korc M. Overexpression of acidic and basic fibroblast growth factors in human pancreatic cancer correlates with advanced tumor stage. Cancer Res. 1993; 53:5289-5296.

157. Coleman SJ, Chioni AM, Ghallab M, Anderson RK, Lemoine NR, Kocher HM and Grose RP. Nuclear translocation of FGFR1 and FGF2 in pancreatic stellate cells facilitates pancreatic cancer cell invasion. EMBO Mol Med. 2014; 6:467-481.

158. Meyer GE, Yu E, Siegal JA, Petteway JC, Blumenstein BA and Brawer MK. Serum basic fibroblast growth factor in men with and without prostate carcinoma. Cancer. 1995; 76:2304-2311.

159. Cronauer MV, Hittmair A, Eder IE, Hobisch A, Culig Z, Ramoner R, Zhang J, Bartsch G, Reissigl A and Radmayr C. Basic fibroblast growth factor levels in cancer cells and in sera of patients suffering from proliferative disorders of the prostate. Prostate. 1997; 31:223-233.

160. Giri D, Ropiquet F and Ittmann M. Alterations in expression of basic fibroblast growth factor (FGF) 2 and its receptor FGFR-1 in human prostate cancer. Clin Cancer Res. 1999; 5:1063-1071.
161. Rasmuson T, Grankvist K, Jacobsen J and Ljungberg B. Impact of serum basic fibroblast growth factor on prognosis in human renal cell carcinoma. Eur J Cancer. 2001; 37:2199-2203.

162. Aigner A, Brachmann P, Beyer J, Jäger R, Raulais D, Vigny M, Neubauer A, Heidenreich A, Weinknecht S and Czubayko F. Marked increase of the growth factors pleiotrophin and fibroblast growth factor-2 in serum of testicular cancer patients. Ann Oncol. 2003; 14:1525-1529.

163. Pasieka Z, Stpie H, Komorowski J, Koomecki K and Kuzdak K. Evaluation of the levels of bFGF, VEGF, sICAM-1, and sVCAM-1 in serum of patients with thyroid cancer. Recent Results Cancer Res. 2003; 162:189-194.

164. Aguayo A, Kantarjian H, Manshouri T, Gidel C, Estey E, Thomas D, Koller C, Estrov Z, O'Brien S, Keating M, Freireich E and Albitar M. Angiogenesis in acute and chronic leukemias and myelodysplastic syndromes. Blood. 2000; 96:2240-2245.

165. Perez-Atayde AR, Sallan SE, Tedrow U, Connors S, Allred E and Folkman J. Spectrum of tumor angiogenesis in the bone marrow of children with acute lymphoblastic leukemia. Am J Pathol. 1997; 150:815-821.

166. Bieker R, Padro T, Kramer J, Steins M, Kessler T, Retzlaff S, Herrera F, Kienast J, Berdel WE and Mesters RM. Overexpression of basic fibroblast growth factor and autocrine stimulation in acute myeloid leukemia. Cancer Res. 2003; 63:7241-7246.

167. Krejci P, Dvorakova D, Krahulcova E, Pachernik J, Mayer J, Hampl A and Dvorak P. FGF-2 abnormalities in B cell chronic lymphocytic and chronic myeloid leukemias. Leukemia. 2001; 15:228-237.

168. Kini AR, Kay NE and Peterson LC. Increased bone marrow angiogenesis in B cell chronic lymphocytic leukemia. Leukemia. 2000; 14:1414-1418.

169. Menzel T, Rahman Z, Calleja E, White K, Wilson EL, Wieder R and Gabrilove J. Elevated intracellular level of basic fibroblast growth factor correlates with stage of chronic lymphocytic leukemia and is associated with resistance to fludarabine. Blood. 1996; 87:1056-1063.

170. Gruber G, Schwarzmeier JD, Shehata M, Hilgarth M and Berger R. Basic fibroblast growth factor is expressed by CD19/CD11c-positive cells in hairy cell leukemia. Blood. 1999; 94:1077-1085.

171. Giles FJ, Vose JM, Do KA, Johnson MM, Manshouri T, Bociek G, Bierman PJ, O'Brien SM, Kantarjian HM, Armitage JO and Albitar M. Clinical relevance of circulating angiogenic factors in patients with nonHodgkin's lymphoma or Hodgkin's lymphoma. Leuk Res. 2004; 28:595-604.

172. Vacca A, Ribatti D, Presta M, Minischetti M, Iurlaro M, Ria R, Albini A, Bussolino F and Dammacco F. Bone marrow neovascularization, plasma cell angiogenic potential, and matrix metalloproteinase-2 secretion parallel progression of human multiple myeloma. Blood. 1999; 93:3064-3073. 
173. Sezer O, Jakob C, Eucker J, Niemöller K, Gatz F, Wernecke $\mathrm{KD}$ and Possinger K. Serum levels of the angiogenic cytokines basic fibroblast growth factor (bFGF), vascular endothelial growth factor (VEGF) and hepatocyte growth factor (HGF) in multiple myeloma. Eur J Haematol. 2001; 66:83-88.

174. Pazgal I, Zimra Y, Tzabar C, Okon E, Rabizadeh E, Shaklai $\mathrm{M}$ and Bairey O. Expression of basic fibroblast growth factor is associated with poor outcome in non-Hodgkin's lymphoma. Br J Cancer. 2002; 86:1770-1775.

175. Salven P, Teerenhovi L and Joensuu H. A high pretreatment serum basic fibroblast growth factor concentration is an independent predictor of poor prognosis in non-Hodgkin's lymphoma. Blood. 1999; 94:3334-3339.

176. Ho CL, Sheu LF and Li CY. Immunohistochemical expression of basic fibroblast growth factor, vascular endothelial growth factor, and their receptors in stage IV non-Hodgkin lymphoma. Appl Immunohistochem Mol Morphol. 2002; 10:316-321.

177. Gonzalez RM, Seurynck-Servoss SL, Crowley SA, Brown M, Omenn GS, Hayes DF and Zangar RC. Development and validation of sandwich ELISA microarrays with minimal assay interference. J Proteome Res. 2008; 7:24062414.

178. Rodriguez-Porcel M, Zhu X-Y, Chade AR, Amores-Arriaga B, Caplice NM, Ritman EL, Lerman A and Lerman LO. Functional and structural remodeling of the myocardial microvasculature in early experimental hypertension. Am J Physiol Heart Circ Physiol. 2006; 290:H978-H984.

179. Wang L, Park H, Chhim S, Ding Y, Jiang W, Queen C and Kim KJ. A novel monoclonal antibody to fibroblast growth factor 2 effectively inhibits growth of hepatocellular carcinoma xenografts. Mol Cancer Ther. 2012; 11:864-872.

180. Zong F, Fthenou E, Wolmer N, Hollosi P, Kovalszky I, Szilak L, Mogler C, Nilsonne G, Tzanakakis G and Dobra K. Syndecan-1 and FGF-2, but not FGF receptor-1, share a common transport route and co-localize with heparanase in the nuclei of mesenchymal tumor cells. PLoS One. 2009; 4:e7346.

181. Prasse AA, Zauner T, Büttner K, Hoffmann R and Zuchner T. Improvement of an antibody-enzyme coupling yield by enzyme surface supercharging. BMC biotechnology. 2014; $14: 88$.

182. Candela ME, Geraci F, Turturici G, Taverna S, Albanese I and Sconzo G. Membrane vesicles containing matrix metalloproteinase9 and fibroblast growth factor2 are released into the extracellular space from mouse mesoangioblast stem cells. J Cell Physiol. 2010; 224:144151.

183. Gutiérrez J and Brandan E. A novel mechanism of sequestering fibroblast growth factor 2 by glypican in lipid rafts, allowing skeletal muscle differentiation. Mol Cell Biol. 2010; 30:1634-1649.
184. Waisberg DR, Parra ER, Barbas-Filho JV, Fernezlian S and Capelozzi VL. Increased fibroblast telomerase expression precedes myofibroblast -smooth muscle actin expression in idiopathic pulmonary fibrosis. Clinics. 2012; 67:1039-1046.

185. DO MKQ, Suzuki T, Gerelt B, Sato Y, Mizunoya W, Nakamura M, Ikeuchi Y, Anderson JE and Tatsumi R. Timecoordinated prevalence of extracellular HGF, FGF2 and TGF3 in crushinjured skeletal muscle. Anim Sci J. 2012; 83:712-717.

186. Kujawski M, Kortylewski M, Lee H, Herrmann A, Kay H and $\mathrm{Yu} \mathrm{H}$. Stat3 mediates myeloid cell-dependent tumor angiogenesis in mice. J Clin Invest. 2008; 118:3367.

187. Slaton JW, Perrotte P, Inoue K, Dinney CP and Fidler IJ. Interferon-alpha-mediated down-regulation of angiogenesis-related genes and therapy of bladder cancer are dependent on optimization of biological dose and schedule. Clin Cancer Res. 1999; 5:2726-2734.

188. Sun XH, Geng XL, Zhang J and Zhang C. miRNA-646 suppresses osteosarcoma cell metastasis by downregulating fibroblast growth factor 2 (FGF2). Tumour Biol. 2015; 36:2127-2134.

189. Colombo G, Margosio B, Ragona L, Neves M, Bonifacio S, Annis DS, Stravalaci M, Tomaselli S, Giavazzi R, Rusnati M, Presta M, Zetta L, Mosher DF, Ribatti D, Gobbi M and Taraboletti G. Non-peptidic thrombospondin-1 mimics as fibroblast growth factor-2 inhibitors: an integrated strategy for the development of new antiangiogenic compounds. J Biol Chem. 2010; 285:8733-8742.

190. Smith JA, Madden T, Vijjeswarapu M and Newman RA. Inhibition of export of fibroblast growth factor-2 (FGF2) from the prostate cancer cell lines PC3 and DU145 by Anvirzel and its cardiac glycoside component, oleandrin. Biochem Pharmacol. 2001; 62:469-472.

191. Alessi P, Leali D, Camozzi M, Cantelmo A, Albini A and Presta M. Anti-FGF2 approaches as a strategy to compensate resistance to anti-VEGF therapy: longpentraxin 3 as a novel antiangiogenic FGF2-antagonist. Eur Cytokine Netw. 2009; 20:225-234.

192. Inoue K, Chikazawa M, Fukata S, Yoshikawa C and Shuin T. Frequent administration of angiogenesis inhibitor TNP-470 (AGM-1470) at an optimal biological dose inhibits tumor growth and metastasis of metastatic human transitional cell carcinoma in the urinary bladder. Clin Cancer Res. 2002; 8:2389-2398.

193. Marshall JL, Wellstein A, Rae J, DeLap RJ, Phipps K, Hanfelt J, Yunmbam MK, Sun JX, Duchin KL and Hawkins MJ. Phase I trial of orally administered pentosan polysulfate in patients with advanced cancer. Clin Cancer Res. 1997; 3(12 Pt 1):2347-2354.

194. Ferro V, Dredge K, Liu L, Hammond E, Bytheway I, Li C, Johnstone K, Karoli T, Davis K, Copeman E and Gautam A. PI-88 and novel heparan sulfate mimetics inhibit angiogenesis. Semin Thromb Hemost. 2007; 33:557-568. 
195. Zhou S, Wang F, Hsieh TC, Wu JM and Wu E. Thalidomide-a notorious sedative to a wonder anticancer drug. Curr Med Chem. 2013; 20:4102-4108.

196. Liekens S, Leali D, Neyts J, Esnouf R, Rusnati M, Dell'Era P, Maudgal PC, De Clercq E and Presta M. Modulation of fibroblast growth factor-2 receptor binding, signaling, and mitogenic activity by heparin-mimicking polysulfonated compounds. Mol Pharmacol. 1999; 56:204-213.

197. Sehgal SN. Sirolimus: its discovery, biological properties, and mechanism of action. Transplant Proc. 2003; 35(3 Suppl):7S-14S.

198. Tayel A, Abd El Galil KH, Ebrahim MA, Ibrahim AS, El-Gayar AM and Al-Gayyar MM. Suramin inhibits hepatic tissue damage in hepatocellular carcinoma through deactivation of heparanase enzyme. Eur J Pharmacol. 2014; 728:151-160.

199. Hagedorn M, Zilberberg L, Lozano RM, Cuevas P, Canron $\mathrm{X}$, Redondo-Horcajo M, Gimenez-Gallego G and Bikfalvi A. A short peptide domain of platelet factor 4 blocks angiogenic key events induced by FGF-2. FASEB J. 2001; 15:550-552.

200. Matsui J, Funahashi Y, Uenaka T, Watanabe T, Tsuruoka A and Asada M. Multi-kinase inhibitor E7080 suppresses lymph node and lung metastases of human mammary breast tumor MDA-MB-231 via inhibition of vascular endothelial growth factor-receptor (VEGF-R) 2 and VEGF-R3 kinase. Clin Cancer Res. 2008; 14:5459-5465.

201. Popat S, Mellemgaard A, Fahrbach K, Martin A, Rizzo M, Kaiser R, Griebsch I and Reck M. Nintedanib plus docetaxel as second-line therapy in patients with non-smallcell lung cancer: a network meta-analysis. Future Oncol. 2015; 11:409-420.

202. Ayers M, Fargnoli J, Lewin A, Wu Q and Platero JS. Discovery and validation of biomarkers that respond to treatment with brivanib alaninate, a small-molecule VEGFR-2/FGFR-1 antagonist. Cancer Res. 2007; 67:68996906.

203. Ueda Y, Shimoyama T, Murakami H, Yamamoto N, Yamada Y, Arioka H and Tamura T. Phase I and pharmacokinetic study of TSU-68, a novel multiple receptor tyrosine kinase inhibitor, by twice daily oral administration between meals in patients with advanced solid tumors. Cancer Chemother Pharmacol. 2011; 67:1101-1109.

204. Inaba Y, Kanai F, Aramaki T, Yamamoto T, Tanaka T, Yamakado K, Kaneko S, Kudo M, Imanaka K, Kora S, Nishida N, Kawai N, Seki H, Matsui O, Arioka H and Arai Y. A randomised phase II study of TSU-68 in patients with hepatocellular carcinoma treated by transarterial chemoembolisation. Eur J Cancer. 2013; 49:2832-2840.

205. Angevin E, Lopez-Martin JA, Lin CC, Gschwend JE, Harzstark A, Castellano D, Soria JC, Sen P, Chang J, Shi M, Kay A and Escudier B. Phase I study of dovitinib (TKI258), an oral FGFR, VEGFR, and PDGFR inhibitor, in advanced or metastatic renal cell carcinoma. Clin Cancer Res. 2013; 19:1257-1268.
206. Bello E, Colella G, Scarlato V, Oliva P, Berndt A, Valbusa G, Serra SC, D'Incalci M, Cavalletti E, Giavazzi R, Damia $\mathrm{G}$ and Camboni G. E-3810 is a potent dual inhibitor of VEGFR and FGFR that exerts antitumor activity in multiple preclinical models. Cancer Res. 2011; 71:1396-1405.

207. Sequist LV, Cassier P, Varga A, Tabernero J, Schellens JH, Delord J-P, LoRusso P, Camidge DR, Medina MH and Schuler M. Abstract CT326: Phase I study of BGJ398, a selective pan-FGFR inhibitor in genetically preselected advanced solid tumors. Cancer Res. 2014; 74(19 Supplement):CT326-CT326.

208. Perera T, Jovcheva E, Vialard J, Verhulst T, Esser N, Wroblowski B, Gilissen R, Freyne E, King P and Platero S. JNJ-42756493 is an inhibitor of FGFR-1, 2, 3 and 4 with nanomolar affinity for targeted therapy. Cancer Res. 2014; 74(19 Supplement):1738-1738.

209. Dransfield D, Lee J, Waghorne C, Bull C, Savage RE, Zhao X, Yuan S, Chang E, Nakuci E and Eathiraj S. Abstract A278: ARQ 087, a multi-tyrosine kinase inhibitor with potent in vitro and in vivo activity in FGFR2 driven models. Mol Cancer Ther. 2013; 12(11 Supplement):A278-A278.

210. Zhao G, Li W-y, Chen D, Henry JR, Li H-Y, Chen Z, Zia-Ebrahimi M, Bloem L, Zhai Y and Huss K. A novel, selective inhibitor of fibroblast growth factor receptors that shows a potent broad spectrum of antitumor activity in several tumor xenograft models. Mol Cancer Ther. 2011; 10:2200-2210.

211. Ochiiwa H, Fujita H, Itoh K, Sootome H, Hashimoto A, Fujioka Y, Nakatsuru Y, Oda N, Yonekura K and Hirai H. Abstract A270: TAS-120, a highly potent and selective irreversible FGFR inhibitor, is effective in tumors harboring various FGFR gene abnormalities. Mol Cancer Ther. 2013; 12(11 Supplement):A270-A270.

212. Qing J, Du X, Chen Y, Chan P, Li H, Wu P, Marsters S, Stawicki S, Tien J and Totpal K. Antibody-based targeting of FGFR3 in bladder carcinoma and $t(4 ; 14)$-positive multiple myeloma in mice. J Clin Invest. 2009; 119:1216.

213. Trudel S, Bergsagel PL, Singhal S, Niesvizky R, Comenzo RL, Bensinger WI, Lebovic D, Choi Y, Lu D and French D. (2012). A phase I study of the safety and pharmacokinetics of escalating doses of MFGR1877S, a fibroblast growth factor receptor 3 (FGFR3) antibody, in patients with relapsed or refractory $\mathrm{t}(4 ; 14)$-positive multiple myeloma. ASH Annual Meeting Abstracts, pp. 4029.

214. Batley BL, Doherty AM, Hamby JM, Lu GH, Keller $\mathrm{P}$, Dahring TK, Hwang O, Crickard $\mathrm{K}$ and Panek RL. Inhibition of FGF-1 receptor tyrosine kinase activity by PD 161570 , a new protein-tyrosine kinase inhibitor. Life Sci. 1997; 62:143-150.

215. Pardo OE, Latigo J, Jeffery RE, Nye E, Poulsom R, Spencer-Dene B, Lemoine NR, Stamp GW, Aboagye EO and Seck1 MJ. The fibroblast growth factor receptor inhibitor PD173074 blocks small cell lung cancer growth in vitro and in vivo. Cancer Res. 2009; 69:8645-8651. 
216. Panek RL, Lu GH, Klutchko SR, Batley BL, Dahring TK, Hamby JM, Hallak H, Doherty AM and Keiser JA. In vitro pharmacological characterization of PD 166285, a new nanomolar potent and broadly active protein tyrosine kinase inhibitor. J Pharmacol Exp Ther. 1997; 283:1433-1444.

217. Panek RL, Lu GH, Dahring TK, Batley BL, Connolly $\mathrm{C}$, Hamby JM and Brown KJ. In vitro biological characterization and antiangiogenic effects of PD 166866, a selective inhibitor of the FGF-1 receptor tyrosine kinase. J Pharmacol Exp Ther. 1998; 286:569-577.

218. Fischer H, Taylor N, Allerstorfer S, Grusch M, Sonvilla G, Holzmann K, Setinek U, Elbling L, Cantonati H and GraslKraupp B. Fibroblast growth factor receptor-mediated signals contribute to the malignant phenotype of nonsmall cell lung cancer cells: therapeutic implications and synergism with epidermal growth factor receptor inhibition. Mol Cancer Ther. 2008; 7:3408-3419.

219. Zhou W, Hur W, McDermott U, Dutt A, Xian W, Ficarro SB, Zhang J, Sharma SV, Brugge J and Meyerson M. A structure-guided approach to creating covalent FGFR inhibitors. Chem Biol. 2010; 17:285-295.

220. Herbert C, Schieborr U, Saxena K, Juraszek J, De Smet F, Alcouffe C, Bianciotto M, Saladino G, Sibrac D and Kudlinzki D. Molecular mechanism of SSR128129E, an extracellularly acting, small-molecule, allosteric inhibitor of FGF receptor signaling. Cancer Cell. 2013; 23:489-501.
221. Bono F, De Smet F, Herbert C, De Bock K, Georgiadou M, Fons P, Tjwa M, Alcouffe C, Ny A and Bianciotto M. Inhibition of tumor angiogenesis and growth by a smallmolecule multi-FGF receptor blocker with allosteric properties. Cancer cell. 2013; 23:477-488. 